
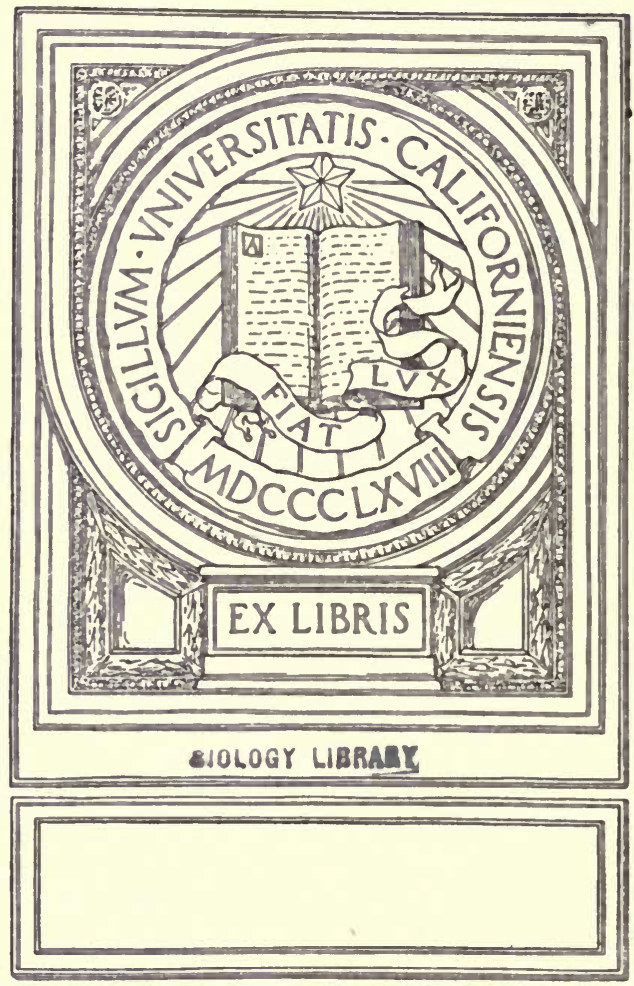





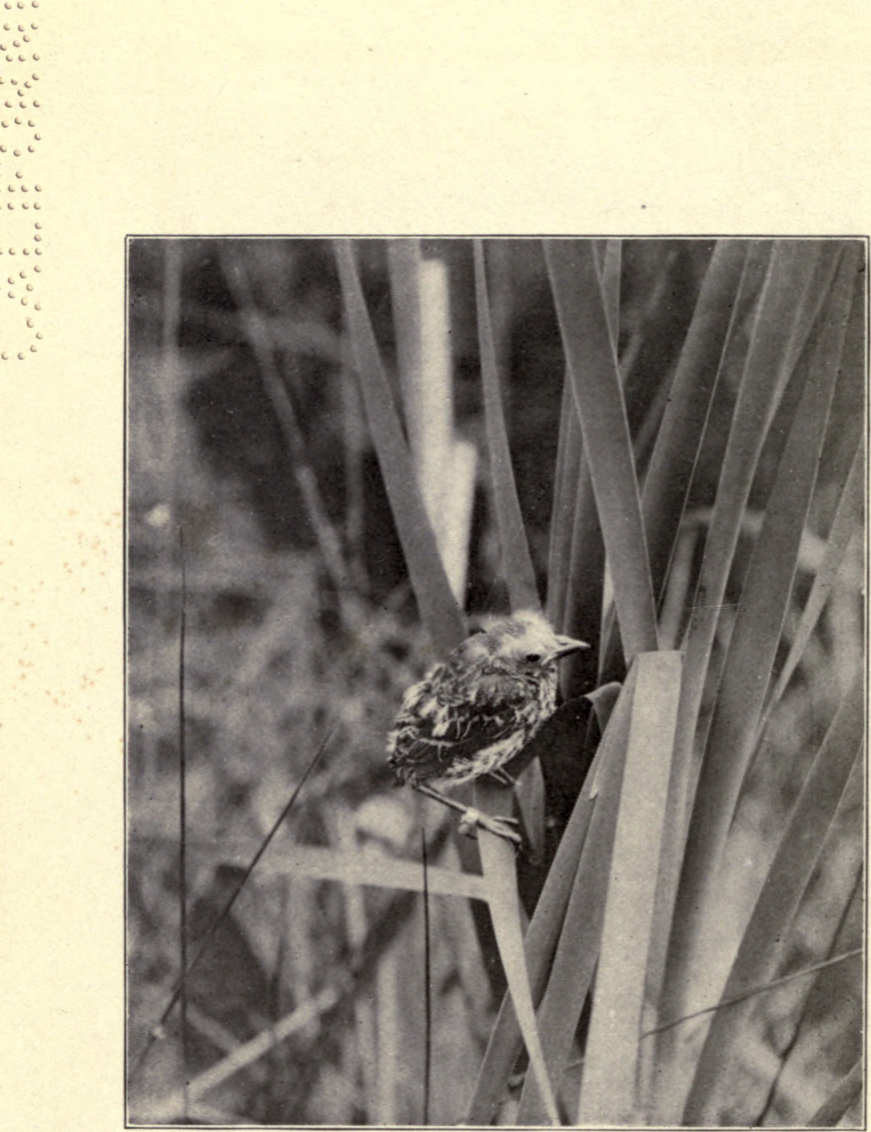

Photo by A. C. Redfield RED-WINGED BL.ACKBIRD FLEDGLING 


\section{The Ornithology of Chester County, Pennsylvania}

\section{BY \\ Franklin Lorenzo Burns}

IN CO-OPERATION WITH LOCAL ORNITHOLOGISTS

"The burnished bluebird with the spring-time song;

The azure-winged runnel's April call;

The timid wren, the falcon fierce and strong;

The soaring water-fowl, the swooping fall;"

-T. Buchanan Read

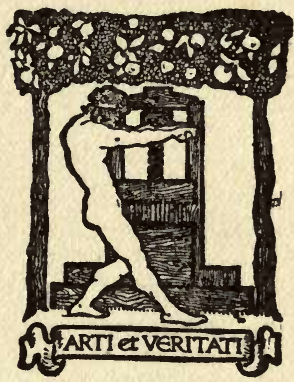

BOSTON

RICHARD, G, BADGER

THE GORHAM 'PRES'S 
(lopyright, 1919, by Richard G. Badger All Rights Reserved

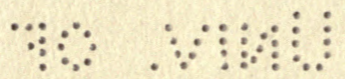

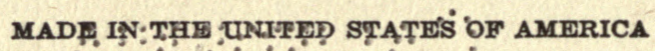

$\therefore: \because \because \because \because: \div \div \div: \because \because \circ$

THH GORHAM Priss, Boston, U. S. A. 


\section{CONTENTS}

\section{PART I}

Physical Features, Habitats, Biographical Notes and Review of Faunal Lists ........ 9

\section{Part II}

Annotated List $\ldots \ldots \ldots \ldots \ldots \ldots \ldots \ldots, 29$

\section{Part III}

Bibliography of Faunal Lists ........ 115

Notes.$\ldots \ldots \ldots \ldots \ldots \ldots \ldots \ldots \ldots \ldots 119$ 



\section{LIST OF ILLUSTRATIONS}

FACING PAGE

Red Winged Blackbird Fledgling....Frontispiece Ideal Sketch of Westtown Boarding School in $1810 \ldots \ldots \ldots \ldots \ldots \ldots \ldots \ldots \ldots \ldots \ldots . \ldots \ldots$

Vincent Barnard ................ II

Ezra Michener, M. D. ............ 20

Charles J. Pennock ............... 21

B. Harry Warren, M. D............ 30

Thomas H. Jackson ............... 31

Black-Crowned Night Heron Nest and Eggs. . 40 Night Hawk Eggs in Situ............ 41 Turkey Vulture Nestling Two or Three Weeks Old .................. 52 Young Turkey Vulture About Ten Weeks Old $\ldots \ldots \ldots \ldots \ldots \ldots \ldots \ldots \ldots \ldots \ldots \ldots \ldots \ldots$

Great Horned Owls Fifteen Weeks Old.... 64 Barn Owls Ten Weeks Old........... 65 Acadian Flycatcher Nest and Eggs....... 76 Indigo Bunting Nest and Eggs......... 77 White-Eyed Vireo on Nest ............ 88 Black and White Warbler Nest and Eggs.... 89 Worm-Eating Warbler Nest and Eggs...... 100 Blue-Winged Warbler Nest and Eggs..... IOI Yellow-Breasted Chat on Nest .......... II4 Kentucky Warbler Nest and Eggs......... 115 

THE ORNITHOLOGY OF CHESTER COUNTY 



\section{ORNITHOLOGY}

PART I

PHYSICAL FEATURES, IIABITATS, BIOGRAPHICAL NOTES AND REVIEW OF FAUNAL LISTS

Chester county lies in the southeastern part of Pennsylvania, bordering the states of Delaware and Maryland from the Brandywine to the Octoraro, and extends northward to about $40^{\circ} 15^{\prime}$ on the Schuylkill. With the exception of the extreme southeastern townships, its area of 780 square miles is a part of the Delaware river system. Chester valley cuts through the centre in a southwesterly direction at a depth varying from 200 to 400 feet, and from 500 to 2,000 yards wide for practically the entire distance of 30 miles; dividing the county in not unequal parts. For almost two hundred years this valley has been almost entirely deforested and under cultivation; in consequence its wild animal life is less varied than that of the wooded hills on either side. It would appear, however, that the Killdeer, Red-headed Woodpecker and Grasshopper Sparrow are more constant breeders here than elsewhere in the county, and the Mallard and Blackcrowned Night Heron are peculiar to the broad and deep eastern part.

The northern half of the county is a succession of hills and vales to the Welsh mountain (elevation 728 feet above the sea at Waynesburg). From the 
latter region spring the main branches of the Brandywine creek, which flows in a southeasterly direction and for 35 miles drains a large portion of the county; the only extensive marsh land (several hundred acres) lies near its source. The French, Pickering and Valley are the most important creeks flowing into the Schuylkill, and at Valley Forge where the latter creek empties into the river, the elevation is less than 75 feet. In recent times the Rough-winged Swallow has been the most characteristic bird of the Schuylkill river banks.

The southern part of the county is only less undulating; the eastern section drained by the headwaters of the Darby, Crum, Ridley and Chester creeks, which, with the united streams of the Brandywine river, the Red Clay and the White Clay creeks; flow into the Delaware. The Big Elk creek empties into the head of the Chesapeake bay, and the Octoraro into the Susquehanna river. It is from this region that we occasionally have record of stragglers from the Austroriparian fauna.

While the county is abundantly watered by small streams, the absence of large bodies of water account for the comparative scarcity of water fowl and shore birds. As early as 1748 , according to Peter Kalm, the woods were mainly deciduous, and free of underbrush on account of the annual burning indulged in by the small bands of the Lenni Lenapes located in Willistown and along the Brandywine.

The Chester Valley and Brandywine hills are famous breeding grounds of the Turkey Vulture, 


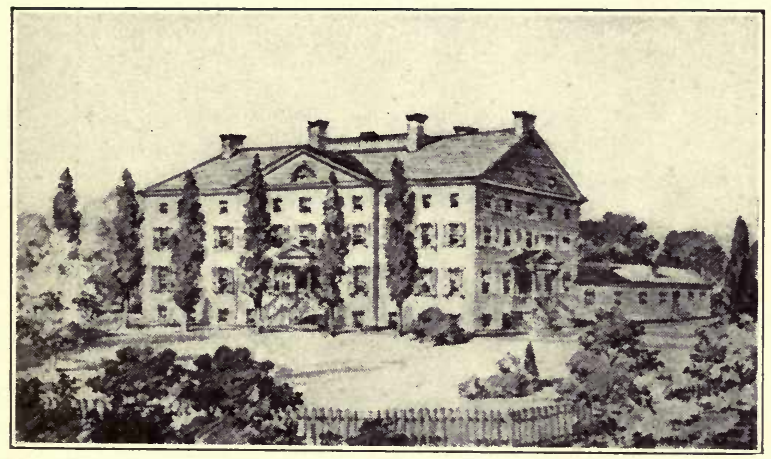

IDEAL SKETCH OF WESTTOWN BOARDING SCHOOL IN I8IO 


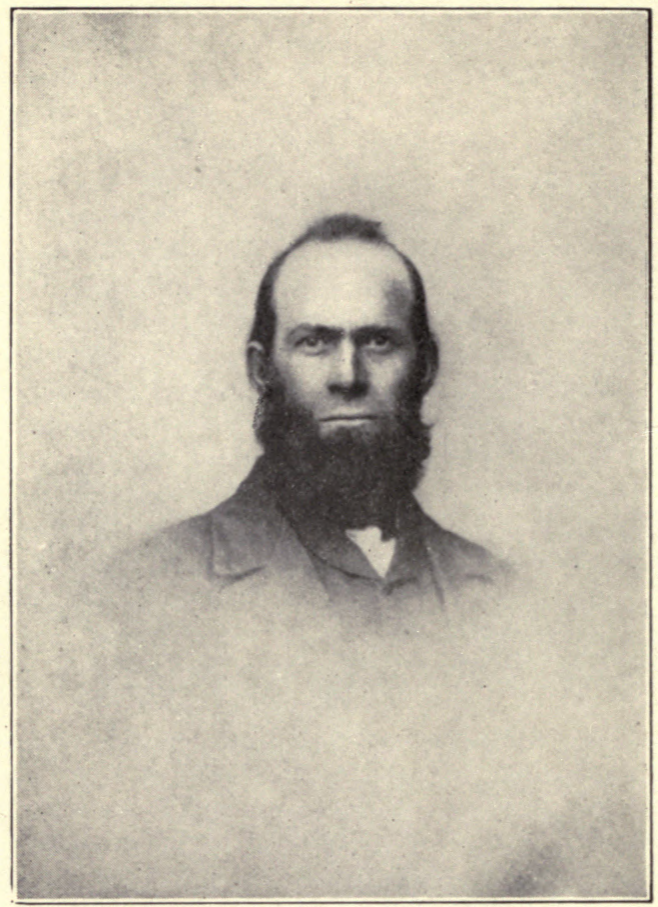

VINCENT BARNARD 
Broad-winged Hawk, Acadian Flycatcher, Fish Crow, Worm-eating and Kentucky Warblers (the Barn Owl, Cardinal, Blue-winged Warbler and Chat being equally abundant in the Chester valley, and the Mockingbird, Carolina Wren, Tufted Tit and Carolina Chickadee are more often found in the southern part of the county); all are more or less typical of the Carolinian fauna.

The Black-billed Cuckoo, Scarlet Tanager and Black and White Warbler are more or less common, and the occasional presence in the summer of the Bobolink, Swamp Sparrow, Rose-breasted Grosbeak, Tree Swallow, Chestnut-sided Warbler and Redstart, would suggest that a more careful survey of the somewhat higher ground of the northwestern section might reveal a stronger element of the Transition zone.

The so-called "Paoli barrens" is an exposed bed of serpentine rock, about eight miles in length and from a few hundred feet to more than a mile in breadth; beginning more than a mile south of Paoli and extending nearly to West Chester. The few inches of humus gives sufficient sustenance to a coarse native sedge grass, a tangle of greenbriers (Smilax glauca and S. rotundifolia) and a stunted growth to scattered groves of scrub-oak (Quercus stellata, Q.marylandica, Q.ilicefolia and Q.pruioides), red cedar (Iuniper virginiana), pitch pine (Pinus rigida), and among the common herbaceous plants, Talinum teretifolium ${ }^{1}$ is typical of the serpentine. In this untillable tract the Mourning Dove, Long-eared Owl and Nighthawk find congen- 
ial homes, the local strain of the Bobwhite made its last stand, and tradition says that the Heath Hen inhabited this growth in early Colonial times. A similar and more extensive tract occurs in Elk and Nottingham townships, extending into Maryland; where the pitch pine is the dominant tree and the Prairie Warbler a regulas breeder.

Anomalism in habitat is exemplified in the absence or extreme scarcity of breeding members of the Red-tailed Hawk and the Great Horned Owl on the ridge forming the Delaware-Schuylkill watershed, where the Cooper's Hawk is common. The paucity of winter visitants on this ridge cannot be attributed to insufficient food or shelter, but I think it is altogether due to the northern visitor following the line of the least resistance on either side, i. e. the valleys of the Delaware or Schuylkill.

Local ornithologists have been most active and more numerous in the vicinity of Kennett Square, Westtown, West Chester, Coatesville and Berwyn; neighborhoods originally settled largely by the English, Welsh, Scotch-Irish and German members of the Society of Friends, commonly called Quakers ; ${ }^{2}$ to whom the study of the natural sciences seemed peculiarly agreeable. Few like sections have been more carefully worked than the south-central to the eastern part of Chester county, and specimens from this region may be found in nearly every large collection.

Near the close of the eighteenth century, John J. Audubon ${ }^{3}$ settled at "Mill Grove" on the banks of the Perkiomen and Schuylkill, opposite Valley Forge 
and just beyond the county line. With the exception of a two years' visit to France, he resided here until $\mathrm{I} 808$, returning to visit his father-in-law at "Fatland Ford" in.1812 and 1824. His enthusiastic search for ornithological material doubtless often found him on Chester county soil and as some of his published notes apply to either side of the river, he may be considered our first ornithologist.

Thomas Say ${ }^{4}$ entered the Friends' Boarding School of Westtown, in May, I799, being the seventeenth boy admitted to the newly established school. In those days the register number was regarded as of great importance and placed on all clothing. Most of the school farm of 600 acres along the Chester creek was primeval forest at this time and for many years later, although the deer and bear had disappeared. While here, young Say, no doubt learned much bird-lore useful later in Governmental work, but the discipline then in vogue appeared too severe for one of his peculiarly sensitive nature and he seemed to have acquired and retained in after life to his detriment, an intense dislike for his teachers and for all ordinary branches of study.

Early in 1819 , John K. Townsend, ${ }^{5}$ then a lad of little more than nine years, entered the Westtown school. Another pupil ${ }^{6}$ of that period writes entertainingly of a poaching adventure that cost him and his newly found friend a sound birching. Taking a page out of the squirrel's book, it was the custom of the students of this school to hoard fruit and nuts in boxes hidden away in the earth. For this 


\section{The Ornithology of Chester County}

purpose the boy was engaged in filling his sack in the school orchard, "out of bounds," when "Jack" Townsend, his shirt bosom distended with apples; crossed his path under the low branches of an apple tree, and as he was about to direct the new boy where the best fruit lay, he espied the broad-brimmed hat of the teacher approaching along the hedge. He writes of Townsend: Active in mind, ardent in temperament, full of life and indefatigable in the pursuit of an idea that once possessed his mind. I have known him to watch for days a pair of birds constructing their nest, and far more interested in the operation than in the irksome study of an indoors lesson, although fully up to any one in his class. It was at this early age that the incipient ornithologist appeared.

Under the stimulus of some great works on American ornithology, some of our brightest students attempted the study of the local birds and if the second quarter of the nineteenth century failed of being the golden period of ornithology in Chester county, it was due to Quaker modesty.

John K., and his cousin, William P. Townsend, and perhaps one or two others, of West Chester; were the first to form a nearly complete collection of local birds in the county, and the former while collecting for Dr. Ezra Michener at New Garden in 1833 , took the unique Townsend's Bunting. In 1826, the Chester County Cabinet of Science was established in West Chester, and when the organization moved into their own building erected in 1836, it was entered in the minutes that "the 
Ornithological department has specimens of most of the birds that make their home with us during the spring and summer, as well as those that are but transient visitors." This exhibit doubtless includes the Townsend collection, as well as those personally collected and mounted by Philip P. Sharples, ${ }^{8}$ then lecturing in the building on chemistry and philosophy. No catalogue of this collection appears, although it is still in part preserved in the Normal School Library. John Cassin, ${ }^{9}$ short, thickset and genial; entered Westtown School from Providence, Delaware county, in October, 1829, and probably soon found place among the legion of youthful egg collectors that flourished in the school "in spite of all sumptuary laws and abolition"; though he later became one of the most bookish of ornithologists.

In the spring of 1833 , Dr. Thomas B. Wilson, ${ }^{11}$ the generous patron of the Philadelphia Academy of Natural Sciences; bought a farm at New London, where he summered and collected until I84I.

Benj. M. Everhart ${ }^{11}$ of West Chester, was another of our pioneer naturalists, and though he specialized in botany, he was interested in birds as early as 1839 and for nearly half a century later.

William L. Baily ${ }^{12}$ of Philadelphia, who entered Westtown School early in 1839 , was a proficient artist and taxidermist. He spent some of his summers in the vicinity of West Chester.

Lucius D. Price, ${ }^{13}$ of West Chester, was also a close student of bird life, and H. B. Graves, ${ }^{14}$ also of West Chester until the last few years of his 
life when he removed to Geiger's Mill, Berks county ; a close friend of Everhart's and one of the few professional taxidermists of his day in the State; has several important county records resting on his authority: the Gull-billed Tern, Great Gray Owl and Bohemian Waxwing.

Major General George A. McCall, ${ }^{15}$ whose ornithological work seems to have been confined almost wholly to the Soutliwest; resided at his home "Belair," West Goshen township, from 1855 to 1861 , and from 1863 until his death.

Prof. E. D. Cope ${ }^{16}$ was another Westtown scholar, and it is said that after the age of thirteen, his summer intervals of boarding school life and later of tutoring were filled among the woods, fields and streams of Chester county, where an intimate knowledge of birds was added to that of batrachians, reptiles and insects. I have a few highly prized bird skins taken by him in 1858 and 1859 at London Grove, Elk creek and elsewhere in Chester county.

J. W. Sharp ${ }^{17}$ of Berwyn formed the nucleus of a sportsmen's collection between 1858 and 1880 . It consisted largely of mounted specimens of the Game birds and Raptores. My earliest recollection was of this exhibit at "Hawthorn Farm." It contained a number of species now unobtainable.

Willis P. Hazard ${ }^{18}$ moved to East Bradford in 1865 and living there continuously until I904, when his residence "Maple Knoll" was destroyed by fire. Ye was a student of ornithology although he seems to have done little active field work. In the course of his business as a bookman and publisher, he 
acquired much Wilsoniana of the highest value and superintended the publication of the Porter \& Coates edition of Wilson, Ord and Bonaparte's American Ornithology, in which he used Wilson's own copper plates.

A Quakeress devotee to natural science and painting, Graceanna Lewis ${ }^{19}$ of "Sunnyside," Kimberton; under the date of July 12th, 1868, published the first part of a scientific treatise presented in popular form; said to contain a number of original observations, especially on eggs and four text figures representing diagramatically the evolution and classification of birds, of which a considerably modified system was proposed. This extremely rare paper is dedicated to Prof Cassin. Apparently the publishers did not meet with sufficient encouragement to warrant a continuation of the parts. I have not seen it and am indebted to Dr. Richmond of the Smithsonian Institution for a copy of the title ${ }^{20}$ and a resume of the contents.

Sara Louisa Oberholtzer, ${ }^{21}$ poetess and a student of birds, studied under Miss Lewis, perhaps.

The first county list was published in 1861 by Vincent Barnard ${ }^{22}$ of London Grove, naturalist, artisian and universal genius; from observations probably begun about 1850 . This list of 191 species, similar to most all early faunal lists, contains very brief annotations, but appears to have few errors in species. "Grus americanus Ord" doubtless is a misidentification of the Grus specimen secured by Michener. The Mississippi Kite, which is understood to have been based upon a view of an 


\section{The Ornithology of Chester County}

individual flying over on Oct. 20,1852 ; is also probably erroneous, since the date is well within the period when the Marsh Hawk frequents the county, and as the author does not include the latter species in his list, it is possible that he may have mistaken it in the gray plumage of the male. Michener's Warbler appears to have been an immature Connecticut Warbler, though there may be a reasonable doubt since the type taken by Michener in Chester county in the autumn of 1839 , cannot be found. Barnard's collection was purchased by the Swarthmore College.

Dr. Ezra Michener ${ }^{23}$ of "Sylvania," Avondale, practitioner, poet and naturalist; was one of the earliest of our local ornithologists, though he did not publish his first list until two years after Barnard. The material, however, he informs us later, was collected mostly between the years of 1834 and 1840. He omits the water birds for want of space, and one species, the Red-winged Blackbird, doubtless unintentionally. The list of 186 species is freely annotated and while it contains some mistakes, represents by far the best efforts of the author. Redcockaded Woodpecker and Gray-cheeked Thrush are probable errors since they do not appear in his later list; while the Black Hawk, Mottled Owl, Michener's Warbler and Wood Wren appear identical with well known species, as he suspects.

Dr. Michener made the following quaint record on comparison of his own and Barnard's lists: "29th of 1st mo., 1861.-There have been discovered in the County, to this time Two Hundred Species; and 
there are forty-five which may yet be discovered."

Professional taxidermists in the past have found here a good field for collecting. C. D. Wood ${ }^{24}$ of Philadelphia, secured at Coatesville, Townsend's Warbler, the sole Eastern record. Harry Garrett ${ }^{25}$ collected about his home in Willistown township for many years and his collection was purchased by the Swarthmore College; later he moved to West Chester and probably helped Josiah Hoopes ${ }^{26}$ form his splendid collection of North American land birds, now in the Academy of Natural Sciences of Philadelphia.

Thomas $\mathrm{H}$ (oopes) Jackson of West Chester, penned the first authentic description of the nidification of the Worm-eating Warbler in 1869 , and he has long been the leading authority on our breeding Raptores and Wood Warblers. Among the oological collectors of this period or earlier were E. J. Darlington, ${ }^{27}$ Dr. W(illiam) L(ivingston) Hartman and J. Hoopes Matlack, ${ }^{28}$ all of West Chester; also B. A. Hoopes, ${ }^{29}$ of Philadelphia and Downingtown, an ornithologist better known as the original describer of Krider's Hawk, named in honor of the Philadelphia taxidermist ${ }^{30}$ so well known in Chester county.

Samuel N(icholson) Rhoads wrote from the Westtown School and C(harles) F (rederic) P (hillips) in 1876 , published notes on 21 species found near Kennett Square; mostly breeding records of more or less importance at that date. Dr. B (enjamin) Harry Warren of West Chester, published a complete list of 218 species in $1879-1880$. Weeding 


\section{The Ornithology of Chester County}

out all synonyms with the exception of Michener's Warbler, he includes the species given by Barnard and Michener; rejecting only the Gray-cheeked Thrush, and perhaps unconsciously, the Pine Warbler; 29 species only rest solely upon the authority of his predecessors, of which 3 seem undoubtedly erroneous as I have already shown. He has added 12 new species to the county, most of them with more or less circumstantial annotations; the most important being Leach's Petrel, the only record for the State; including, however, the White Gyrfalcon, which is not recognized in his later publications; likewise the Migratory Quail, which failed to become established. Dr. Warren's continued activity resulted in several subsequent additions, the most notable being Audubon's Warbler, the second Eastern record for this species.

Dr. Michener's second paper appeared in $188 \mathrm{I}$, long after he had transferred his attention to other branches of natural history. This is a formal list of names compiled from Barnard, Warren, his own earlier list, manuscript of Harry Garrett and a few undesignated species he thought ought to be found in the county; the few annotations being in the form of footnotes. Since he remarks that "the number of species which have actually been found in our county is about 220 ," and has actually recorded no less than 232 species including two synonyms; all species without satisfactory annotations and without record elsewhere up to this time, must be considered hypothetical; they are the Red-breasted Merganser, Baldpate, Green-winged Teal, Pintail, Canvas-back, 


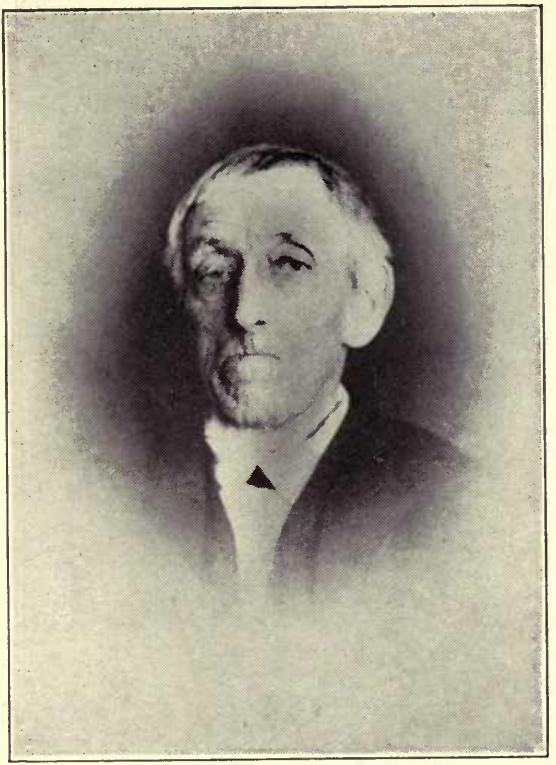

EZRA MICHENER, M. D. 


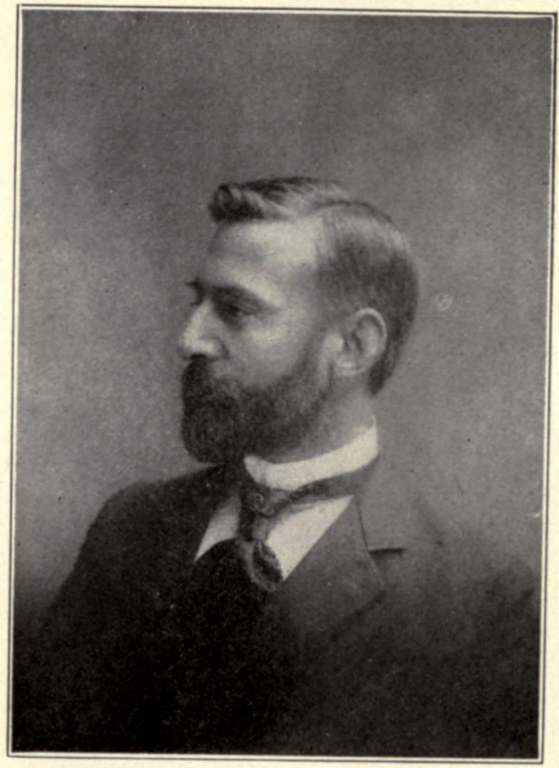

CHARLES J. PENNOCK 
Scaup Duck, Ring-necked Duck, American Goldeneye, Old-squaw, Whistling Swan, Least Bittern, Yellow Rail, Northern Phalarope, Dowitcher, Pectoral Sandpiper, Dunlin and Long-billed Curlew. The White-winged Crossbill has apparently been omitted inadvertantly. Michener is responsible for the sole State records of the Greater Shearwater and Sandhill Crane. His collection was deposited with Swarthmore College and with those of Barnard and Garrett, destroyed by fire.

About this time or somewhat later, Samuel B (ragg) Ladd, Willard L(orraine) Maris, Joseph Parker Norris, Jr., S (amuel) Edward Paschall, G. W. Roberts, ${ }^{31}$ Robert $\mathbf{P}$ (ennell) Sharples and Edward Swayne, collected and reported from about West Chester; M. P. Barnard, ${ }^{32}$ Asher Palmer and William M(arshall) Swayne, Jr., Kennett Square; Alfred P. Lee, Oxford; Harry Wilson and George C. Maule, Gum Tree; William B(arnard) Coates, Parkesburg; Hugh E(xton) Stone and Witmer Stone, Coatesville; Albian Garrett and W. S. Hall, ${ }^{33}$ Willistown; Robert, Harry and William S. Everett, Green Tree; A (nthony) Wayne Baugh, Paoli; F. L. Burns, Grant Groff and Dr. W. E. Rotzell, ${ }^{34}$ Berwyn, and Dr. William E. Hughes, Phonixville; a number being keen oologists. A great deal of the data and specimens from which J. Parker Norris, Sr., ${ }^{35}$ compiled his interesting description of series of sets of eggs are of Chester county origin.

Dr. Warren's second list, including only those he personally found breeding, is dated Aug. 27 (addendum, Sept. 8), 1885, and totals 80 species. The 
material to a large extent was obtained in the townships of Willistown, Pocopson, Newlin, and those bordering West Chester. With the assistance of his friend, Benj. M. Everhart, he compiled a number of interesting local names. As the list was prepared for a newspaper, the technical names were omitted, though the species are checked with numbers to correspond to those used by Ridgway in his Nomenclature of 1881 , for the benefit of scientific contemporaries.

C. J. Pennock ${ }^{86}$ of Kennett Square, in March, 1886, published his original list, which apparently had a very limited circulation among ornithologists and is now quite scarce. This paper is compiled from the writer's own observations and the published lists of his predecessors, and adds one new species to the county: the Wood Ibis, taken by his uncle, Vincent Barnard. In common with Michener, Pennock appears especially concerned in the economic value of the bird as revealed by its food habits, and his oological inclination given expression in brief notes on nidification. The list, though meritorious, exhibits every evidence of haste and is unequal to the high standard of his later papers. He has included Michener's hypothetical species, ${ }^{37}$ the questionable Mississippi Kite, White Gyrfalcon and Redcockaded Woodpecker, of which there appears no satisfactory record; as well as several other species without indicating that they had long since become locally extinct; on the other hand the Black-throated Green Warbler has doubtless been omitted unintentionally. The list embraces 236 species, of which 
215 species appear authentic. A revised edition with new notes and observations on the nidification of some half a dozen species, bringing it up to December Ist, 1886; appeared early in the following year. At the suggestion of the author, the publisher attempted a rearrangement of the common and scientific names to correspond with those recently adopted by the American Ornithologists' Union. The result was not altogether satisfactory; for instance: Mareca americana American Widgeon appeared as "Anas penelope Widgeon," Sandhill Crane became "Little Brown Crane," Spiza townsendi Townsend's Bunting was interpretcd as "Passerella iliaca unalaschcensis Townsend's sparrow," and Yellow Palm Warbler appeared as "Palm Warbler."

Cyrus B. Ressel's list of 199 species was published in 1889 and superficially bears the stamp of an experienced ornithological writcr. Most of the observations appear to have been made in the vicinity of Ercildoun, in the western part of the county, and much of the data is from the collection of William D. Doan of Coatesville. It is regrettable that the ostensible author offered some extraordinary records of the recent occurrence of the following species: Red-breasted Merganser, European Widgeon, Green-winged Teal, Pintail, Redhead, Scaup, Whistling Swan, Snowy Egrit, Golden Eagle, Hawk Owl, Red-shafted Flicker, Yellow-headed Blackbird, Dickcissel, Blue Grosbeak, Bohemian Waxwing, Prothonotary, Cerulean and Yellowthroated Warblers; none of which can be accepted without satisfactory verification. There also appear 
a large number of unusual and several manifestly impossible breeding records, including the American Bittern, Great Blue Heron, Red-shouldered Hawk, Barred Owl, Yellow-bellied Flycatcher, Least Flycatcher, Lincoln's Sparrow, Rose-breasted Grosbeak, Tree Swallow, Golden-winged, Nashville, Parula, Blackburnian, Pine and Hooded Warblers, Waterthrush, Redstart, Chickadee, Blue-gray Gnatcatcher and Wilson's Thrush; according to competent critics, a most questionable list, especially so many rarities to have fallen to the lot of a novice. Some years later, I published some of the manuscript notes furnished me by $\mathrm{Wm}$. D. Doan, including disagreements in dates and localities or disavowal in toto of many of the more important records given in Ressel's list; also my final decision to reject all of this. unsatisfactory matter, especially as the Doan collection is no longer extant. It is refreshing to turn to the work of Dr. Thos. H. Montgomery, ${ }^{38}$ Professor of Zoology in the University of Pennsylvania; issued in 1897. It is one of our best local lists, avoiding the larger and rather misleading title so often given to personal and neighborhood lists. The periods of observation were from 1885 until I891, and again renewed in 1895 . The greater part of the collecting was limited to a five mile radius of West Chester, i. e. the higher ground of West Whiteland, East and West Goshen townships, and along the Brandywine in East Bradford township. All the species listed were shot and identified by the author, with the exception of a few taken by collecting friends, and no species included unless the 
author had seen it in the flesh. Dr. Montgomery added two new species to the county: the Semipalmated Plover and Migrant Shrike, and also included some other very interesting records. His specimens are deposited in the Philadelphia Academy of Natural Sciences.

Recently, Chreswell J(ohn) Hunt has written something of the birds about Cupola, and he is our sole informant from the Honeybrook and Welsh mountain region.

With the new century came the era of the rsthetics, for the most part non-collecting ornithologists. Some of the observers may be recorded here: Caspar G(reen) Burn, Oxford; C(harles) Aubrey Thomas, Kennett Square; Willima B (acon) Evans, George $\mathrm{H}$ (ervey) Hallett, Jr., Charles W (arner) Palmer and Edith Smedley, Westtown; Mrs. Hugh P. Brinton, John D(arlington) Carter, Sarah C(ole) DeHaven, Dr. Clyde E(rnst) Ehinger, George Forsythe, Isaac G(arrett) Roberts, William E(ly) Roberts, Dr. S(amuel) C(hristian) Schmucker and Francis Windle, ${ }^{39}$ West Chester; William Carter, Lenape and Mendenhall; Dr. Howard Y(arnall) Pennell, Downingtown; Guy L(ivingston) Eadie and John B (oyd) Gill, Berwyn; Mildred Cornelius and Henry Justice, Devon; and Edwin B (unting) Bartram, Frazer and Strafford. In addition to the above, William L(loyd) Baily, 2nd, occasionally recorded from Paoli; Dr. Spencer Trotter from Cheyney, and a small coterie from Wayne, Delaware county; Leonard S(now) Pierson, Alfred $\mathrm{C}$ (larence) Redfield and Charles $\mathrm{H}$ (enry) Rogers, 
accomplished good work in the vicinity of Berwyn. In I90I, the writer of this sketch published a sectional bird census, taken at Berwyn. This was the first List from the eastern border and embraced only the breeding birds; it was followed by a similar one in 1915, showing the slight changes in the number of individuals in the same area over a period of years.

In consideration of the popular character of the foregoing and for the sake of brevity, I have, where ever possible, used the common English "book" names of the species in preference to the scientific or technical terms usually employed. In many instances these names have been in use for a long time in this section; also, not being subject to the laws of priority, they are less liable to change, and all are perfectly intelligible to the average English-speaking ornithologist. Many of the names have the additional merit of perpetuating the vernacular of our Colonial forefathers, to whom the appellation conveyed some real or fancied characteristic of the species, and they are altogether most expressive both in prose and poetry.

The ornithological literature of the county is large, I regret that it is not feasible to include a complete bibliography; but reference to the more important contributions appear in the annotated catalogue of species. I am indebted to the following persons for biographical notes or portraits: W. L. Baily, Gilbert Cope, Ruthven Deane, Watson W. Dewees, Wm. B. Evans, J. Comly Hall, Prof. J. W. Harshberger, Rev. W. H. Hazard, Mrs. Bernard A. Hoopes, J. P. Norris, Jr., Chas. W. Palmer, 
Mrs. C. J. Pennock, Miss Josephine Pennock, C. B. Ressel, Dr. C. W. Richmond, Alfred D. Sharples, Robert P. Sharples, Jefferson Shaner, Dr. Witmer Stone, Wm. M. Swayne, Jr., Dr. B. H. Warren, Ezra Webster and M. B. Worth; for ornithological notes and comments: Mrs. H. P. Brinton, C. G. Burn, J. D. Carter, Miss Sarah C. DeHaven, J. B. Gill, Dr. W. L. Hartman, C. J. Hunt, Thos. H. Jackson, A. C. Redfield, Isaac G. Roberts, Robt. P. Sharples, Dr. Witmer Stone, C. A. Thomas, Dr. B. H. Warren, Harry Wilson and others.

My own observations began in the summer of I 884 , have continued without a break of more than a few months at a time, up to the present, and extends over the eastern and northeastern parts of the county, with short visits to the south-central and extreme west. My migration records began in the spring of 1885 with a few common migrants, have now reached the thirty-third year, and I am informed that it is the only continuous record for this period in Eastern Pennsylvania. However, sometimes during the most critical time of bird migration, the period of my observation may have been limited to the brief time of going to and returning from my work. I have therefore reserved the right to eliminate a few of my records which according to my judgment are not representative of the true period of arrival or departure; and it was probably with this in mind that prompted the late Prof. W. W. Cooke to write me a short time before his death, urging the publication of my averages and extreme dates. Also the long-term averages taken independently so near 
Philadelphia, may prove interesting in comparison with the valuable combination averages by Dr. Stone for the Delaware Valley Ornithological Club.

I have been at some disadvantage in working alone, especially when unable to make frequent visits to the habitats of extremely local species, but on the other hand the percentage of error may possibly be less than where several observers of less experience work a neighborhood. My experience in horizon and census work has taught me something of comparative abundance and I believe my averages for bulk arrival and departure to be of greater value and more nearly correct than the averages of first arrival and last seen; especially taking in consideration the utter impossibility of always distinguishing the bona fide first arrival from the occasional holdover.

Migration at Berwyn is seldom as well marked as in many other sections of the county; especially the vernal flight, when many of the smaller local land birds appear tardily via the Darby creek, and others pass in a northeasterly direction. The visible autumnal movement is more direct and attended with greater numbers; the usual route southwesterly, the day fliers: Killdeer, Dove, Hawks, Blue Jay, Grackles, Blackbirds, Swallows and Robin; the Canada Goose and Nighthawk, by day or night, and the Sandpiper by night. It is only occasional that a great movement is detected in the nightfliers, like that of September 24th, 1916, when the sky was partly overcast, the clouds thin and low, with moderate west wind; the air appeared alive with whispering voices of the small migrants at no great height, from dusk to late at night. 


\section{PART II}

\section{ANNOTATED LIST}

I. Colymbus holbolli Holbœll's Grebe. Rare winter visitant, apparently included by Barnard and Pennock upon personal observation. I have record of a flock of six observed on Valley Forge dam, Feb. IO, 1903, and there are two recent records at Kennett Square, Feb. 9, 1904, and Feb. 15, 1912, the last a capture (Pennock, Cassinia, viii, 54 ; xvi, 44).

2. Colymbus auritus Horned Grebe. Rather rare transient visitant, though listed by all but Montgomery. Mar. 29-Apr. 20. I have a female (No. 580 , coll. F. L. B.) found dead under the telegraph wires at Paoli, Apr. 20, I 896 (Wilson Bulletin, No. $8,6)$. The additional records that have come to my notice are: Westtown, Mar. 29, I9I I, by G. H. Hallett, and Apr. 5, 1913, by Emily M. Webster; Kennett Square, Apr. 16, 1914, by C. A. Thomas (Cass., xv, 53; xvii, 40; xviii, 50). There are no spring dates.

3. Podilymbus podiceps Pied-billed Grebe, "dabchick," "dipper," "hell diver," "little diver." Not very common transient, most frequent in spring. Apr. 7 (I9I I)-May 2 (1915); Ave. 4 years, Apr. 12. Two fall records are available both at Berwyn, Sept. 25, 1902, and Aug. 27, 1913. In Highland Twp. it is sometimes found in winter. A living specimen was taken from a flock of five or six on Buck run, in December, IgO2 (Wilson MS.). 
4. Gavia immer I.oon, "big diver," "great northern diver." Not common transient visitant, though it appears on all our county lists. Migration dates: Apr. 26 (1915)-May 30 (1909) and again Nov. 14 (1908)-Nov. 25 (1909). A flock appeared in the Chester valley on Nov. 14, 1908, during a N. E. snowstorm, and a pair secured from a small dam on the Chesterbrook farm (Nos. 934 and 935, coll. F. L. B.) ; another female lingered on a pond a mile further up the Valley creek until Dec. 10, when it was found dead and in an emaciated condition (Burns, Wils. Bull., 65, 215, and 66, 18). Under similiar circumstances another catastrophe occurred Nov. 25, 1909; two birds were shot at Paoli, two at Lenape and one seen on a pond near Westtown (Redfield, Ibid., 70, 56).

5. Gavia stellata Red-throated Loon. Straggler. A female (No. 988, coll. F. L. B.) shot on Trotter's dam, near Berwyn, Nov. 15, 1911; is the sole county record (Burns, Auk, xxxii, 1915, 225).

6. Larus argentatus Herring Gull, "gull," "seabird." Rare transient and winter visitant. The following are all the records known to me: Central Chester Co., five noticed flying high overhead, evening of May I I, I 890 (Stene, Birds E. Pa. and N. J., 43) ; Berwyn, flock of sixteen going west at noon, Feb. 19, 1902, and Valley Forge, a single one on the Schuylkill, Jan. 6, I903 (Burns MS.); and Berwyn, two on Apr. 1, 1908 (Redfield, Cass. xii, 53).

7. Larus delawarensis Ring-billed Gull. During a severe storm from the west, Mar. 28, 1911, a crippled straggler was captured on Greystone farm, East 


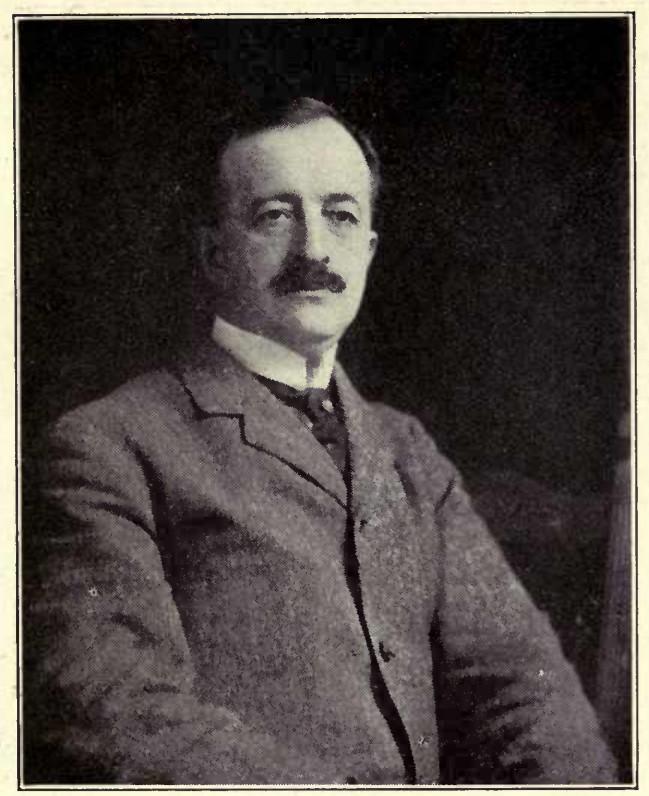

B. HARRY WARREN, M. D. 


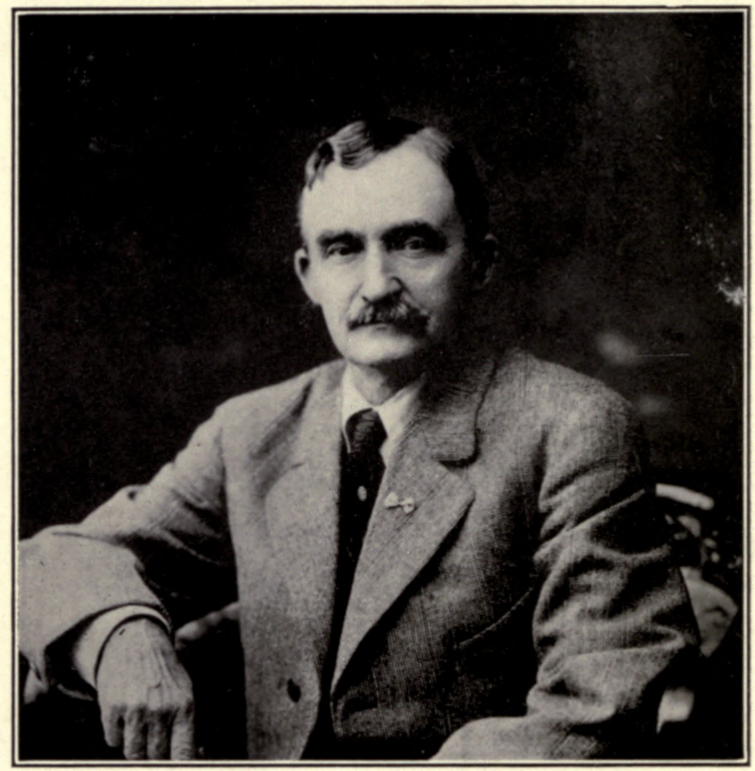

THOMAS H. JACKSON 
Goshen Twp. The skin was mounted and placed in Greystone hall (Sharples MS.).

8. Larus philadelphia Bonaparte's Gull. Straggler. Barnard lists it as very rare, and Warren states that two or three specimens have been taken along the Brandywine.

9. Gelochelidon nilotica Gull-billed Tern. Straggler. H. B. Graves killed a specimen in autumn (Warren, Birds Pa., 23I).

10. Sterna caspia Caspian Tern. Straggler. A male and female blown inland by three days of storm were shot Sept. 28, 1912, at Lenape park on the Brandywine, near West Chester, and are now in the possession of Lewis Darlington (Sharples, Auk, $\mathrm{xxx}, 1913,105)$.

II. Sterna hirundo Common Tern. Straggler. According to Dr. Warren, C. D. Wood has prepared specimens taken in the county, and that it has been captured while migrating in autumn. I may also state that Dr. Montgomery saw an individual of a small species of this genus (perhaps $S$. hirundo) shot on the Brandywine near Lenape, in the late summer of 1887 , but owing to the rapid decomposition of the specimen, he was unable to fully identify the species.

12 Sterna antillarum Least Tern. Straggler. Dr. Warren states that he has seen it taken during the past ten years, in August and September (Bds. Pa., $1890,22)$.

13. Sterna fuscata Sooty Tern. Straggler. Barnard records it as very rare and it is presumed that he made a capture. In the spring of 1878 , a speci- 
men found dead in a field, was presented to Dr. Warren; and this, with a later capture, remain in his collection.

14. Hydrochelidon nigra surinamensis Black Tern. Straggler. Two specimens, male and female, were taken by Titus Bennett, of West Chester, in the fall previous to 1879 ; and this pair, with another collected in the spring; are in the collection of Dr. Warren. Another was killed in the fall two or three years ago (Warren MS.).

15. Puffinus gravis Greater Shearwater. Straggler. This powerful bird, despite its strength and endurance of wing, was storm-stranded within our borders and perished during a severe storm of wind, rain and sleet (Michener, Hist. Chester Co., Pa., 1881, 445). Sole State record.

16. Oceanodroma leucorhoa Leach's Petrel. Straggler. A specimen was presented to Dr. Warren in September, 1879 , by the late Dr. George Martin of West Chester, who had found it in his yard in an exhausted and dying condition (Bds. $\mathrm{Pa}_{\mathrm{a}}, \mathbf{1} 890,27$ ). Sole State record.

17. Mergus americanus Merganser, "fish duck," "sawbill." Rare winter visitant and occurs occasionally as a transient. Listed by Barnard, Warren, Michener and Pennock. A flock of seven attempted to winter, 1910-1911, at the Valley Forge dam; but were reduced to three by Jan. 12, and a dead and water soaked female was found Jan. 15 (No. 982, coll. F. L. B.). It is also recorded by Mrs. H. P. Brinton, West Chester, Mar. 18, 1914 (Cass., xviii, 5I). 
18. Laphodytes cucullatus Hooded Merganser, "fish duck," "hairyhead," "sawbill." In Barnard's time this species was found frequently, but it is now a rather rare transient, or possibly winter visitant. Dr. Warren has the following records: Nov. 23, 1881 ; Apr. 3, 1884; Mar. 26, 1887; June 23, 1890 (Bds. Pa., I890, 35). Three specimens were shot at Cupola, Dec. 12, 1913, and two brought to me but I failed to preserve them.

19. Anas platyrhynchos Mallard, "greenhead," "wild duck." A not common transient, but has recently been successfully introduced in the Chester valley as a resident. In Audubon's time it bred in the beautiful meadows that here and there border the Schuylkill (Orn. Biog.). Dr. Warren states that it has been taken by H. B. Graves, and Pennock considered it as not very common. In the vicinity of Berwyn, in Chester valley; three were seen Apr. 13-i 5, 1900, and about 100 in flocks, Mar. I, 1902. This species was introduced on the East Valley creek seven or eight years ago by Richard Houghton; the eggs coming from Chincoteage island, Md., and now breeds freely for miles up and down the creek, in April and May.

20. Anas rubripes tristis Black Duck, "black mallard," "dusky duck," "wild duck." Not common transient and rare resident. It is listed by Barnard, Michener, Warren and Pennock. A flock of six was seen near Berwyn, in the Chester valley, Nov. 14, 1893. About 1907 there were reports of it being found resident along the East Valley creek, and in the spring a hybrid family of five was raised on a 
little island in a millpond. A year or two later, the species was introduced on an adjacent farm, but were speedially absorbed by the Mallard. It has however, been recently seen during the breeding season on the Schuylkill, above Valley Forge.

21. Chanlelasmus streperus Gadwell. Straggler. Kennett Square, Dec. 26, 1912, an individual was flushed from a millrace and positively identified at a distance of ten feet by C. J. Pennock and C. A. Thomas (Thomas MS.,).

22. Mareca americana Baldpate. An example was shot on the Henry T. Coates dam at Berwyn, about June 20, 1889, and presented to J. W. Sharp. A rare straggler.

23. Querquedula discors Blue-winged Teal. Rare transient. Dr. Montgomery shot an adult and saw another on the Brandywine near Lenape, Aug. 8, 1889; and one was shot on Campbell's dam, Berwyn, Oct. 15, 1909, by N. C. Cass.

24. Spatula clypeata Shoveller. Straggler. Given by Barnard, Warren and Michener as rare. I have not met with it.

25. Dafila acuta Pintail. Straggler. Included on the authority of T. H. Jackson, who has a distinct recollection of being offered a freshly killed specimen by a local gunner, who had shot it on the Brandywine. This was in the early 'gos. Michener includes it in his later list without comment.

26. Aix sponsa Wood Duck, "acorn duck," "summer duck," "wild duck." Rare summer resident and transient. Formerly frequent, according to Barnard. Pennock found it rather common on migrations and 
stated that two broods of young were found in 1886 . A pair raised a brood at Strode's mill dam, near West Chester, a few years ago, and S. B. Ladd had a set of eggs collected for him on the West branch of the Brandywine some years since (Sharples MS.). Wilson writes that pairs are to be found along the unfrequented portions of the Octoraro and occasionally along Buck and Doe run. He mounted a specimen Mar. 30, 1898, shot at Glenville dam, W. Fallowfield Twp. In the vicinity of Berwyn, a pair nested along the Valley creek and three of the young were bagged by a local hunter, Nov. 3, 1891 ; another pair frequented a dam at the head of the Darby creek during the summers of 1909-1910, doubtless nesting in the willows, since the young were seen, and some of the birds shot in the fall. The most recent capture is by C. A. Thomas, Kennett Square, Nov. I4, 1914 (Cass., xviii, 5I).

27. Marila americana Redhead. Straggler. Some thirty years ago, Warren came upon a flock of thirteen near Deborah's rock, along the Brandywine, and secured two (Bds. Pa., 1890,42 ).

28. Marila valisineria Canvas-back. Straggler. Stray individuals, probably lost from flocks migrating in October and November, have been shot by hunters on the Octoraro, Buck run and the west branch of the Brandywine (Wilson MS.).

29. Marila affinis Lesser Scaup, "scaup," "little blackhead." Transient. Barnard and Warren give it as rare, while Pennock states that it is rather common on small streams and ponds in small flocks in spring and fall. We have but one recent definite 
record; West Chester, Apr. 5-6, 1914, by I. G. Roberts (Cass., xviii, 5I).

30. Clangula clangula americana Golden-eye. Straggler. I observed a flock of ten at Valley Forge, Feb. $12,1898$.

31. Charitonetta albcola Buffe-head, "butterball." Transient visitant. Not common, according to Barnard and Warren; while Pennock states that it is frequently met with when migrating.

32. Erismatura jamaicensis Ruddy Duck. Uncommon transient. Barnard considered this species rare and Warren frequent. Pennock states that he knew of several instances of its capture, and Montgomery shot an adult female, Mar. 15, 1890, in a marsh near Lenape, along the Brandywine. There are three later records, all taken at Kennett Square, Apr. 10, 1906, by Pennock, and Apr. 30 and Oct. 23, 1915, by Thomas.

33. Branta canadensis canadensis Canada Goose, "wild goose." Common transient, seldom coming to earth within our limits. On Nov. 25, 1895, a flock of 100 or more individuals confused in a fog, came down on a hill north of Berwyn, but eventually split into three sections and later several were shot on the west branch of the Brandywine (Wils. Bull., No. $7,3)$. On Oct. 16, 1910, a flock of 53 was flushed from the Valley Forge dam by a gunner in a boat; one bird was disabled by flying against the guy wire to a stack, two shot two or three miles up the Valley creek, and the survivors spent the night on the meadows.

Berwyn migration records: 
First spring Feb. 18 (190r)-Mar. 20 (1886). Ave. Io yrs. Mar. II.

Last spring Mar. II (1901)-Apr. I7 (1913). Ave. 10 yrs. Apr. 4.

First fall Oct. IO (1905)-Oct. 29 (1909). Ave. 7 yrs. Oct. 22.

Last fall Oct. 17 (1910)-Dec. 15 (1891). Ave. 17 yrs. Nov. 13.

34. Mycteria americana Wood Ibis. A straggler from the south. According to Pennock, a specimen was taken by the late Vincent Barnard since the publication of his list in 1861 .

35. Botaurus leutiginosus Bittern, "Indian hen," "mud hen." Scarcely common as a transient, Apr. II (1880)-Apr. 26 ( I 880); Aug. 3 (1887)-Dec. 8 ( 1889 ) ; and rare as a summer resident. Montgomery closely. observed one in May, 1895, and Pennock states that specimens have been shot throughout the summer months. A specimen said to have been taken from a nest and three eggs among the tussocks of Doe run, was brought in to be mounted on May I, I897 (Wilson MS.).

36. Ixobrychus exilis Least Bittern. Rare summer resident. Dr. Warren records a specimen taken May 20, 1884 (Bds. Pa., 19), and W. L. Baily observed one at Paoli, May I I, I9I4 (Cass., xviii, 52). The only breeding record is by L. S. Pierson and A. C. Redfield, June 12, 1909; a nest and four eggs in a cat-tail swamp at the head of Darby creek, near Berwyn (Auk, xxvi, 426), and I had the pleasure in verifying the record to my own satisfaction the next day, as well as later visits to observe 
the young. The birds were last seen on Aug. 3 . No search was made on the following year, but an adult was seen July 3 , and it doubtless was breeding.

37. Ardea herodias herodias Great Blue Heron, "big kingfisher," "big blue crane," "big crane," "big blue shitepoke," "blue crane," "brother Jonathan," "crane," "fish crane," "frog eater," "giant heron," "great big fly-up-the-creek." An irregularly common transient and an occasional, solitary, non-breeding summer resident. Earliest date of arrival, Mar. 31 (1900), and latest date of departure, Nov. 18 (1912), in the vicinity of Berwyn. Montgomery noticed a pair during two summers in East Bradford Twp. It has been frequently seen along Buck run during the breeding season, and may have nested, though but a single male has been taken in perfect nuptial plumage (Wilson MS.).

38. Herodias egretta Egret, "white crane." Straggler from the south. Barnard states that it is seldom found. Warren notes a capture in July, I 88I (Bds. Pa., 1890, 60). One was reported shot out of a flock of seven, near Kennett Square, July IO, 1902, by C. J. Pennock (Cass., vi, I6), and a male (No. 771, coll. F. L. B.) was taken along Darby creek near Berwyn, July 26, 1902 (Wils. Bull., 40, 109). Another was observed on the Brandywine, near West Chester, for two weeks during the summer of I9II, by Mrs. H. P. Brinton, and probably the same one was seen near Sugar's bridge, July 26, same year, by Miss S. C. DeHaven (Cass., xvi, 45). 39. Egretta candidissima Snowy Egret, Straggler 
from the south. Admitted on the authority of Warren and Pennock.

40. Florida carula Little Blue Heron, "egret," "little white crane," "white crane." Straggler from the south. An immature female (No. 728, coll. F. L. B.) taken Aug. 4, 1901, on Crum creek, Paoli barrens; appears to be the first county record (Wils. Bull., 36, 72). During the late summer of 1902 , there appears to have been a notable influx of this species: Red Clay creek, near Kennett Square, one was shot from a flock, during the latter part of July, and examined by C. J. Pennock; Brandywine creek, near Lenape, one was seen on Aug. 3, and two afterward shot, according to J. D. Carter; Westtown, one seen with a broken leg Aug. I3, three seen Aug. 14, and two on Aug. 15, by George Forsythe; Cupola, one was shot on the upper Brandywine, Aug. 28, and given to C. J. Hunt, and W. B. Harvey reported it at West Grove, along the White Clay creek. All specimens appear to have been in the white phase (Evans, Cass., vi, 18-20). An immature female was brought in from Buck run, East Fallowfield Twp., in July to be mounted (Wilson MS.).

41. Butorides virescens virescens Green Heron, "chalk-line," "fly-up-the-creek," "little crane," "mudpoke," "poke," "shitepoke." Locally a common summer resident. Arrives in the vicinity of West Grove, Mar. Io to I 8 (Barnard) ; West Chester, Mar. 27 to Apr. 12 (Warren); and Berwyn vicinity, Apr. 9 to May 9. It usually departs early in September, but is occasionally seen as late as 
October 10.

42. Nycticorax nyticorax nycticorax Black-crowned Night Heron, "crane," "Indian hen," "mudhen," "mudpoke," "night heron," "qua-bird," "squawk." Common summer resident, extremely local as a breeder. Barnard considered it rare in his neighborhood, and Montgomery never met with it in the vicinity of West Chester. I have found it rather common along the Octoraro below Atglen, and Harry Wilson reports it probably nesting along Buck run in East Fallowfield Twp., but I believe that these birds are all from the Lancaster county colonies. There is a large herony in the eastern part of the Chester valley, in Tredyffrin Twp. (Burns, Bird-Lore, xix, 197). Nidification begins soon after arrival, average date for complete set, May 10. Thomas notes its arrival at Kennett Square, Apr. 12 (1908)-Apr. 22 (1915), and it doubtless averages several days earlier at its breeding grounds than I am able to offer for Berwyn vicinity:

Arrival-Apr. 15 (1917)-Apr. 30 (1906); ave. 7 yrs. Apr. 20.

Departure-Oct. 6 (I9I I)-Nov. 6 (I893); ave. 3 yrs. Oct. 23 .

43. Nycticorax violacens Yellow-crowned Night Heron. Rare summer resident. On May 14, 1915, I found it present and evidently nesting in the local colony of N.n.nycticorax. An individual, probably not always the same one; was observed circling just above the tree tops on three occasions, and I had a view of it through the glass while it perched close 


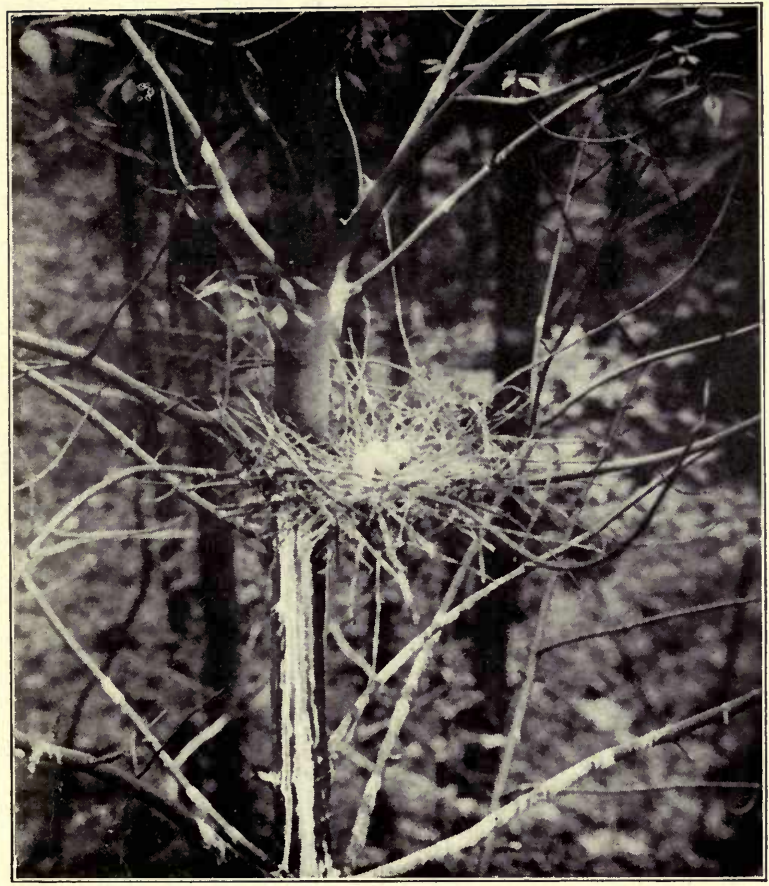

Photo by A. C. Redfield

BLACK-CROWNED NIGHT HERON NEST AND EGGS 


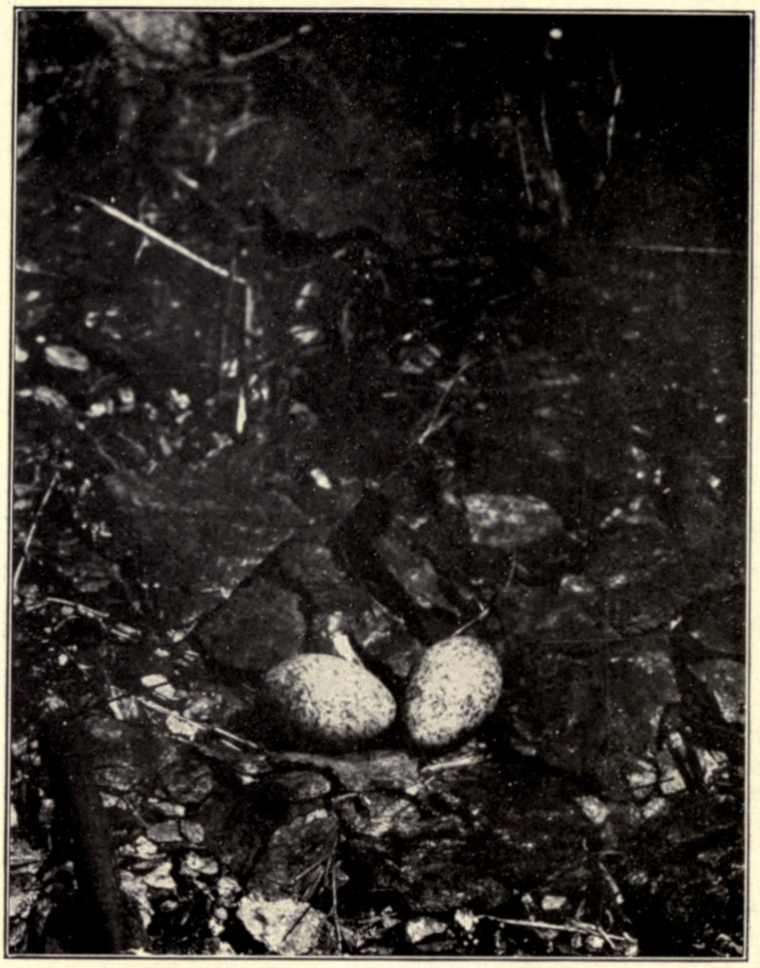

Photo by T. H. Jackson

NIGHTHAWK EGGS IN SITU 
to a nest, though it seemed more wary than the common, lighter species. Unfortunately; on May 28 , the date of my next visit; I found that this outlying part of the herony had been raided by the Crows and N.violacens no longer present. This is the first record for Chester county and the third for Pennsylvania, all of which come from the lower Schuylkill river region. ${ }^{40}$

44. Grus mexicanus Sandhill Crane. Straggler. About I 840 , a flock of four or five individuals moving northward, occurred along the west branch of the White Clay creek; one was shot and presented to Dr. Ezra Michener, who preserved and kept it in his collection for many years; later it came into the collection of the Swarthmore college, where it was lost when the building was burned. At the time of this capture, most American ornithologists recognized with certainty but a single species-Grus americanus the White or Whooping Crane; and Barnard so listed it, doubtless with the full approval of his friend Michener. The latter however in his complete list some twenty years later, gives it as "Grus canadensis Sandhill Crane." Michener's remarks convinces one of his comparison and elimination of G.americanus, and since he followed closely the nomenclature and classification of Baird, it seems improbable that he should have overlooked the "G.fraterculus" of Cassin which refers to the Little Brown Crane rather than G.canadensis (Baird, Birds, 1858,655 ) which in this instance is a synonym of G.mexicanus. Dr. Michener appears to have been an accomplished and conscientious 
ornithologist, and this record should have its proper place on the State lists. ${ }^{41}$

45. Rallus elegans King Rail. Rather uncommon transient, and rare summer resident. According to Dr. Stone it has been found breeding along the Brandywine at Pocopson (Bds. E. Pa. and N. J., 95). An adult female (No. 849 , coll. F. L. B.) with several partly developed eggs in the ovaries, taken at Fetter's mill, near Howeltown, May 4, 1905; would probably have nested (Wils. Bull., $58,32)$. Dr. Warren has obtained several specimens, mostly in August and September (Bds. Pa., I 890, 68), and one was caught by a cat at Kennett Square, Apr. 14, 1906 (Pennock, Cass., x, 48).

46. Rallus virginianus Virginia Rail, "rail bird." A rather rare transient and somewhat local summer resident. There are not many migration records: Nov. 7, 1879, and May 13, 1880, presumably near West Chester, by Dr. Warren; and Berwyn vicinity, Sept. 20, 1890 and Sept. 9, 1908; all captures. Pennock states that two nests were taken in swamps near streams, Kennett Square; one about 1878 by Asher Palmer, and the other was taken by Charles Miller. Five sets were taken in 1886 , including sets by Ladd and Pennock (Oologist, iii, 40 and 46) ; a set of 9 eggs by Jackson on June 2, and a set of I I eggs was found on the same date by another collector (Orn, and Ool., xii, 25). I found a recently deserted nest and heard the grunting notes of the owner, June 14, 1916, in a swamp at the head of Darby creek, Berwyn, where several birds had been taken by gunners on previous seasons. Careful search in fav- 
orable localities may reveal it nesting regularly.

47. Rallus crepitans crepitans Clapper Rail. Straggler. Kennett Square, Apr. 28, 1908 (Pennock MS., communicated by C. A. Thomas).

48. Prozana carolina Sora, "rail," "rail bird," "sora." An uncommon transient and rare summer resident. Dr. Warren has taken specimens May 3, I 882; July 20 and Aug. 12, 1884, and states that it has been found breeding along the Brandywine (Bds. Pa., I890, 71). My Berwyn records are Sept. 5, 1901; Aug. 29 and Sept. 5, 1904; Oct. I6, 1909 .

49. Gallinula galeata Florida Gallinule, "blue rail," "wild hen." Rare transient visitant. Barnard considered it accidental and Pennock as not common. Warren took a specimen May II, I 879 (Bds. Pa. 3I ). A fine specimen of this graceful and pugnaceous bird became dazed by an automobile headlight on the evening of May 4, 1916, was captures by-E. L. Burnham and brought to me to be banded and released. This appears to be the only recent record.

50. Fulica americana Coot, "blue Peter." Not common transient. Warren mentions having examined six specimens taken in the county, but gives no dates. For the vicinity of Berwyn I have two spring records: Apr. 19 and 25, 1903; and three autumnal captures: Nov. 1, 1905; Oct. 9, 1907 (three others seen); and Oct. 16, 1909 (Nos. 875, 908 and 956, coll. F. L. B.).

51. Scolopax rusticola European Woodcock. Straggler. According to Dr. Warren, David M. 


\section{The Ornithology of Chester County}

McFarland killed a large female on the "barrens," East Nottingham Twp., in the early part of November, 1886 (Bds. Pa., 1890,78 ).

52. Philohela minor Woodcock, "bog sucker," "mud snipe," "woodcock," "wood snipe." Not common transient and rare summer resident; formerly abundant and occasionally taken in mild winters. A nest and four eggs was found at Paoli, Apr. 17, 1904, by W. D. Carpenter (Baily, Cass., viii, 64). Barnard gives the spring arrivals as March 10 to 18. The Berwyn migration records as follows:

Arrival Mar. 14 (1885)-Apr. 8 (1891), ave. 5 yrs. Mar. 29.

Departure Nov. 3 (1896)-Nov. 29 (1904), ave. 11 yrs. Nov. 17.

53. Gallinago delicata Wilson's Snipe, "English snipe," "jack snipe," "gray snipe," "robin snipe." A somewhat irregular but not uncommon transient. Dr. Warren states that crippled individuals have been shot near West Chester in summer, also occasionally during warm spells in December and January (Bds. Pa., 1890, 8I). I have compiled the following from all available notes on spring arrival and departure, also fall departure:

Mar. 16 (1908)-Mar. 25 (1905); ave. 6 yrs. Mar. 20.

Apr. I (I884)-May II (I905); ave. 8 yrs. Apr. 15.

Nov. I (1896-1913)-Nov. 23 (1889); ave. 4 yrs., Nov. 7.

54. Pisobia minatilla Least Sandpiper, "peep." Transient. Warren and Pennock consider it com- 
mon. The former states that an acquaintance found a flock of probably 100 feeding on the muddy bottom of an emptied mill dam near West Chester, in the latter part of August, about 1882 (Bds. Pa., 36). Wilson finds it common in Highland Twp. in March and September, often in flocks of ten to fifty. A mounted specimen taken in August, 1884, is in his collection. It has recently been reported by G. H. Hallett, Jr., May 13, Brinton's dam, and May 22, I9I I, Westtown (Cass. Xv, 43).

55. Ereunetes pusillus Semipalmated Sandpiper, "peep." Rare transient. Wilson gives it as a common migrant in Highland Twp., during decade I $880-1890$.

56. Totanus melanoleucus Greater Yellowlegs. Rare transient. Given by Barnard and Michener. There are two recent migration records, both by I. G. Roberts, of West Chester: Apr. 24, I9I I, and May I 7, 1914 (Cass., xv, 55, and xviii, 53).

57. Totanus flavipes Yellow-legs. Rare transient. Dr. Michener considered it frequent, and Dr. Warren has recorded the following captures; Apr. 30 and May 7, 1879; Oct. 10 (4 specimens), 1880; Aug. 30, 1882. (Bds. Pa., 38).

58. Helodromas solitarius solitarius Solitary Sandpiper, "tiltup," "wood peep." Regular transient. Dr. Montgomery has often found it in flocks of considerable size in the spring, and has shot one and seen others in the summer. The data for spring and fall arrival, however, is all too scanty:
May 5 (1880)-May I4 (1883); ave. 7 yrs. May II. 


\section{The Ornithology of Chester County}

Aug. 8 (1906)-Sept. 2 I (1883); ave. 4 yrs. Aug. 29.

59. Symphemia semipalmatus semipalmatus Willet. Straggler. Dr. Warren has a specimen, killed by flying against a telegraph wire along the Brandywine, August, 1887 (Bds. Pa., 1890, 92 ).

60. Bartramia longicauda Upland Plover, "Bartram's plover," "grass plover," "field plover," "upland plover." Rather rare summer resident, formerly common. Dr. Montgomery found it rather common in the higher parts of West Goshen Twp., but never met with it elsewhere. It has recently been found nesting at Westtown, Malvern, Paoli, and in the Chester valley opposite Berwyn. Arrival and departure from all sources are as follows:

Apr. 18 (1907)-May 18 (1902); ave. 10 yrs. May 2.

Aug. 8 (1906)-Sept. 20 (1880); ave. 4 yrs. Aug. 27.

61. Actitis macularia Spotted Sandpiper, "peep," "pee-weet," "pen-wipe," "sand snipe," "tilt," "tilttail," "tilt-up." Tolerable common summer resident, mainly about ponds and the larger streams. Nesting date: Valley Forge, June 19, 1895; four eggs. The following are my Berwyn vicinity records on arrival and departure:

Apr. 14 (1898)-May 14 (1899); ave. Io yrs. May 2.

Sept. II ( 1 896)-Sept. 27 (1895); ave. 2 yrs. Sept. 19.

62. Squatarola squatarola Black-bellied Plover, "bullhead." Rare transient. Listed by Barnard and 
Michener, the latter, influenced by Audubon's erroneous statement, classes it as a summer resident. Dr. Warren has taken two specimens (Bds. Pa., r 890 , 97).

63. Charadrius dominicus dominicus Golden Plover, "bullhead," "field plover." Rare, formerly irregularly abundant autumnal transient. I have heard old gunners speak of the abundance of this species about 1860 in the Chester valley during wheat sowing time. Dr. Warren writes of the largest recent flight in September and October, 1880 ; when flocks of from 50 to 100 were quite plentiful about the plowed fields in the neighborhood of West Chester (Bds. Pa., 44); and also mentions four specimens preserved, taken in West Goshen Twp. in September, and one in Birmingham Twp., Oct. 3, 1880 (Ibid. 45).

64. Oxyechus vociferus Killdeer, "killdee," "killdeer," "meadow plover," "plover." Common summer resident, occasional resident. A solitary individual was seen on Jan. 14, 1889, probably wintering in the vicinity. Nesting data: Chester Valley, May 27, 1 886; three eggs. The Berwyn data on arrival and departure follows:

Feb. 17 (1890)-Apr. 6 (1898); ave. 32 yrs. Mar. 14.

Oct. 4 (1904)-Nov. 22 (r886); ave. 20 yrs. Oct. 31 .

65. Egialitis semipalmata Semipalmated Plover. Straggler. Dr. Montgomery shot two adults in West Goshen Twp., Sept. 12, 1888; the only specimens taken in the county. 


\section{The Ornithology of Chester County}

66. Colinus virginianus virginianus Bobwhite, "partridge," "patridge," "quail." Tolerable common resident in some localities, formerly abundant. I am told that prior to $\mathrm{s} 860$, it was not uncommon for two expert sportsmen to kill as high as sixty birds in an afternoon, in this locality. There is now only a trace of the fine local strain, and the introduced stock being from the south or west is only a temporary success, the exodus begins in a short time.

67. Bonasa umbellus umbellus Ruffed Grouse, "pheasant." Rare resident. The wooded hills on either side of the Chester valley were famous hunting grounds for this king of game birds up to about 1880. I have a specimen (No. 160, coll. F. L. B.) taken Nov. 23, 1889, almost the last individual of this once abundant species at Berwyn. Ladd took a set of 12 eggs, May 9, 1886 (Ool., iii, 40).

68. Tympanuchus cupido Heath Hen, "barren hen." Dr. Michener lists it as a former resident, now become extinct. Tradition would have us believe that it inhabited the greenbrier thickets, scrub oak groves and sterile sedge fields of the barrens in early Colonial times and as there are ample proof that it existed in very similar situation in the Pocono region; I am inclined to give it full credence.

69. Meleagris galloparo silvestris Wild Turkey. Former resident, now extinct. A few may have existed in some parts of the county, especially the Welsh mountain district; as late as 1830 or even somewhat later, since it is listed by Barnard and Michener; but it had disappeared from the culti- 
vated districts at a much earlier period.

70. Phasianus colchicus $+P$. torquatus English Pheasant. Resident. This fine hybrid has become locally established.

71. Ectopistes migratorius Passenger Pigeon, "wild pigeon." Formerly an irregularly abundant transient, now extinct. John D. Dillen states that his earliest recollections of this species dates back to about I 864 when a flock was found roosting in Gibson's pines, a four-acre tract, located on the South Valley hills, Tredyffrin Twp. upon the very spot where "Weadleytown" now stands. The pigeon's stay was always comparatively short, rarely in August, but could be looked for any time between Sept. Io and Oct. IO; nevertheless a flock of about 300 individuals occurred in early November, 1877 or 1878. It was less abundant in spring; a flock of about 50 birds in March, I867, and another of about 200 in March, 1872 or 1873 (Cass., xiv, 33-36). Pennock states that small flocks were seen at Kennett Square from I869 to I873. Dr. H. R. Wharton shot one or two in a wood at Strafford, 1878 , and there is a specimen in the J. W. Sharp collection without data but I understand that it was secured nearby. Dr. Montgomery shot one individual Sept. I, 1886, in Birmingham Twp., and a female in West Goshen Twp., Sept. 9, 1887. Both specimens are in immature plumage and now in the collection of the Academy of Natural Sciences, Philadelphia, and are believed to have been the last specimens taken in Southeastern Pennsylvania. A flock of fifteen passed over Berwyn, April 17, 1901 
(Wils-Bull., 70, 48).

72. Zenaidura macroura carolinensis Mourning Dove, "turtle dove," "wild dove," "wild pigeon." Common summer resident, occasional resident. Berwyn arrival and departure.

Feb. 24 (1906)-Apr. 6 (1914); ave. 17 yrs. Mar. 21.

Sept. 26 (1910)-Nov. 30 (1912); ave. 13 yrs. Oct. 21.

The first set of eggs is completed by Apr. 20.

73. Cathartes aura septentrionalis Turkey Vulture, "buzzard," "turkey buzzard." Common summer resident, more or less regular resident in the southern part of the county. It has been found nesting by Michener, Matlack, Maris (Orn. and Ool., ix, 3) ; Stone (Am. Nat., 1885, 407); Pennock, Warren, Jackson, Burns and others, especially on the hills encompassing the Brandywine and Chester valleys. My Berwyn records of first and last seen:

Mar. 16 (1897)-Apr. I3 (1894-1909); ave. 15 yrs. Apr. 4.

Oct. I I (1907)-Dec. I (1897-1900); ave. 20 yrs. Oct. 23.

It has also been noted on Jan. 30, 1906, and Feb. 25, 1901, doubtless birds that have wintered near by. Nests with eggs are found by May 5 to 20 .

74. Circus hudsonius Marsh Hawk, "bog trotter," "hen hawk." Not common transient and rather rare winter resident. It has been noted in the vicinity of Kennett Square, Westtown and West Chester during the winter. A pair of adults were shot at Berwyn, Apr. 20, I891, and it has been 
noticed as early as Aug. 22 (1878) in East Bradford Twp. Below are the averages from all sources: Aug. 22 (1878)--Nov. 5 (1879); ave. 4 yrs. Sept. 14.

$$
\text { Mar. } 23 \text { (I914)-Apr. } 20 \text { (I89I); ave. } 4 \text { yrs. }
$$
Apr. 7 .

75. Accipiter velox Sharp-shinned Hawk, "arrow hawk," "bird hawk," "little chicken hawk," "little hawk," "partridge hawk," "sharp-shin," "sparrow hawk." Tolerable common transient and rare, though regular, summer resident. Barnard, Michener and $W$ arren considered it as a resident, and it almost comes under this head since there are records for every month with the exception of January. Matlack, Warren and Jackson have found it nesting near West Chester; one or two nests have been taken by Hughes, and Rotzell secured a set of four eggs from a cedar grove near Berwyn, May 23, 1889 (Ool. $x, 300$ ) on which occasion the writer was present. This set is now in the Philadelphia Academy of Natural Sciences. On account of the presence of individuals in early and late winter, no migration averages can be given, but a perceptible autumnal rnovement occurs from Sept. Io to Oct. I6.

76. Accipiter cooperi Cooper's Hawk, "bird hawk," "blue hawk," "chicken hawk," "little hen hawk," "long-tailed hawk," "partridge hawk," "pigeon hawk," "pheasant hawk," "privateer."

Common summer, occasional resident. Nidification commences about Apr. 20 in the vicinity of Berwyn, and the average date for the complete set 


\section{The Ornithology of Chester County}

is May 8. I have not found this species present in January.

77. Astur atricapillus atricapillus Goshawk, "hen hawk." Rather rare winter visitant, usually solitary. Listed by Barnard and Michener. Warren states that he has seen five individuals in ten years; one was shot at Kennett, Jan. I, 1872 (Phillips, F. and S., vi, 84); there is a specimen in the Sharp collection, taken many years ago in Easttown Twp.; and Dr. Hughes reported one killed near Downingtown (Abst. Del. Val. Orn. Club, ii, I898, 2 I). There are also three sight records from West Chester: Dec. 25, 1907, by Ehinger (Bd. Lore, x, 31) ; Feb. 7, 1909, by Jackson (Cass., xiii, 23); and Dec. 25, 1916, by Schmucker and Ehinger (Bd. Lore, xix, 23).

78. Buteo borealis borealis Red-tailed Hawk, "big chicken hawk," "hen hawk," "redtail." Tolerable common resident, formerly rather abundant for a member of the Raptores. It is worthy of remark that Dr. Fisher gave food records of no less than 178 individuals taken in Chester county, mostly in the winter months between 1876 and 1886 , and nearly all from the vicinity of West Chester (Hawks and Owls of the U. S., 53-58). Large flights of transients occurred near Berwyn on Sept. 24, 1905 and Nov. I-3, 1913. It is rather curious that I have not found this species nesting anywhere on the Valley hills. Numerous nests have been found in the vicinity of Kennett Square and West Chester especially, by Warren, Pennock, Jackson, Sharples and others. However, this large, handsome 


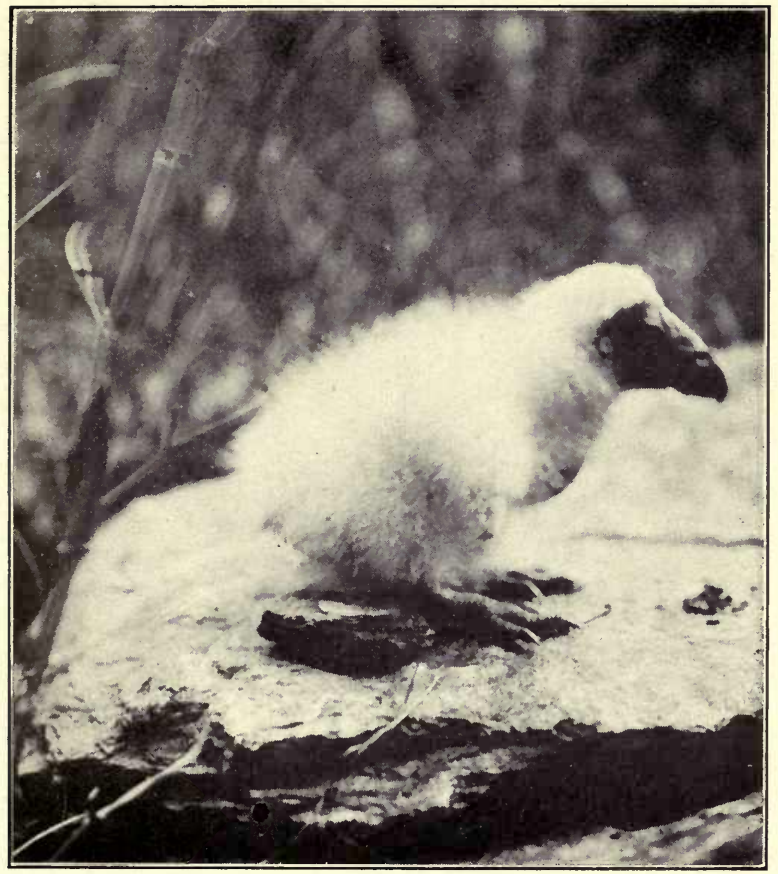

Photo by T. H. Jackson

TURKEY VULTURE NESTLING TWO OR THREE WEEKS OLD 


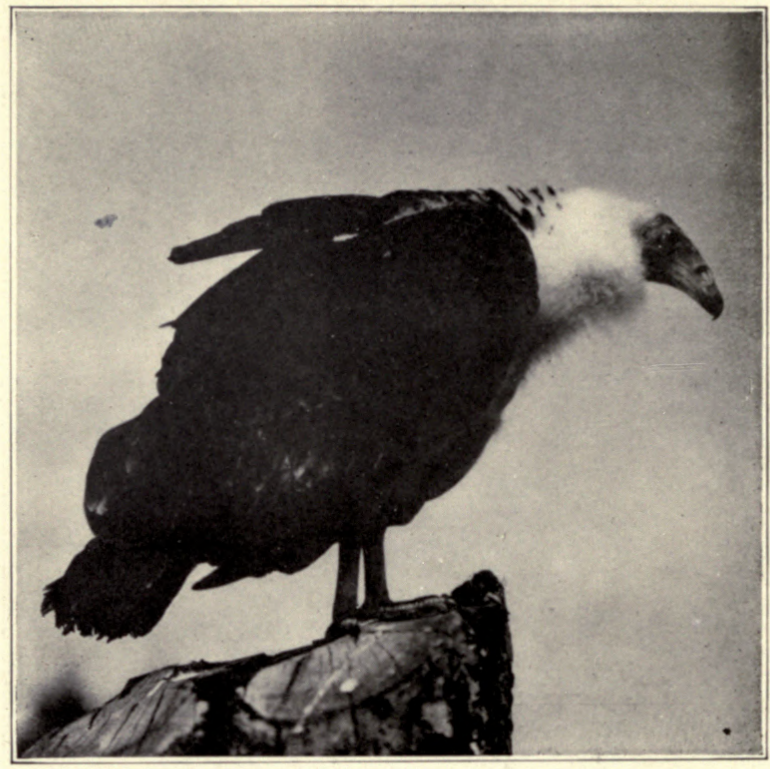

Photo by E. H. Baynes

YOUNG TURKEY VULTURE ABOUT TEN WEEKS OLD 
species is being replaced by the less conspicuous $B$. platypterus.

79. Buteo lineatus lineatus Red-shouldered Hawk, "chicken hawk," "hen hawk," "mouse hawk." Common transient and less common winter resident. Our most abundant Hawk during fall migrations. There appears no authentic breeding records, though, as Dr. Stone points out, we are well within its breeding range. My Berwyn dates on autumnal arrival and vernal departure follow:

Sept. 23 (1902)-Nov. 6 (1894); ave. 8 yrs. Oct. 16.

Feb. II (I89I)-Apr. 5 (I9I7); ave. 9 yrs. Mar. 14.

80. Buteo platypterus platypterus Broad-winged Hawk, "chicken hawk," "broad-wing." Common summer resident. Michener, Warren, Pennock and Montgomery, all consider it resident, but there appear to be no winter dates and it has yet to appear in the local Christmas census. This species, formerly quite rare, is now gradually supplanting B.borealis, but owing to its inconspicuous presence, my Berwyn migration records of its departure are few: Arrival-Mar. 20 (1896)-May 6 (1904); ave. 14 yrs. Apr. 2 I.

Departure-Sept. 6 (1903)-Oct. 10 (1908); ave. 3 yrs. Sept. 21 .

Nest with eggs was found by Phillips at Avondale, Apr. 26, 1869 (F. and S., vi, 84), and with increasing frequency by Matlack, Price, Warren, Everett, Darlington, Jackson, Baugh, Ladd, Sharples; Pennock and Burns, principally on the Chester 
valley and Brandywine hills (Burns, Mon. Broadwinged Hawk, Wils. Bull., Nos. 76-77). Nidification commences by April 25, and the average date for complete set is May 15.

81. Archibuteo lagopus sancti-johannis Roughlegged Hawk, "tiger hawk." Rather rare winter visitant, though it is included in all but Montgomery's list. In the winter of 1879 , while hunting along the Brandywine, Dr. Warren observed seven individuals at one time (Bds. $\mathbf{P a}$., 92). I have, however, only nine or ten specific records, ranging from Dec. 9, 1886, to Mar. 22, I914 (Fisher, Hawks and Owls, 91 ; Ehinger, Bd. Lore, xviii, 28 ; Ms. from Thomas and DeHaven).

82. Aquila chrysatos Golden Eagle. Straggler. Considered very rare by Barnard, Michener, Warren and Pennock. According to Rhoads, one was shot at Oxford in 1881 or 1882 (Stone, Bds. E. Pa. and N. J., 87). Another in immature plumage was winged at Berwyn, Apr. 7, 1894, by George Quigley, and kept in confinement for some years at the Sorrel Horse tavern (Abst. D. V. O. C., ii, 22 ).

83. Haliaetus leucocephalus lencocephalus bald Eagle. Transient and occasional winter visitant, at least rare enough to excite general comment whenever reported. Sept. 9, 1915, to May 22, 1910 (Cass., v, 47 ; xii, 55 ; xiv, 4I ; xvi, 47; Bd. Lore, xii, 29; MS. Burns and Thomas). Dr. Warren narrates that about 1839, B. M. Everhart found within the present borough limits of West Chester a nest with one eaglet which he kept for some time. A nest was located on the North Valley hills, near 
Valley Forge, at a much later date.

84. Falco peregrinus anatum Duck Hawk. Rare winter visitant, and so recorded by Barnard and Michener. Dr. Warren obtained one caught in a steel trap (Penn. Agri. Report for 1833, I09). Dr. Montgomery saw a specimen in the flesh, shot in East Bradford Twp., Feb. 14, 1886; the skin of which is now in the collection of G. W. Roberts. Dr. Fisher gives the food data on an additional specimen, taken in the same locality, Mar. I7, I880 (Hawks and Owls, I09); and there are records of two shot at Lenape, Oct. IO, and Nov., 1902, by J. D. Carter (Cass., vi, 56; vii, 68). The Harry Garrett collection in Willistown, is said to have contained two local specimens.

85. Falco columbarius columbarius Pigeon Hawk. Rare winter visitant, observed by Barnard and Michener. Dr. Warren secured a pair in the suburbs of West Chester; in one week this pair had killed or drove away fifty pigeons from the dovecote of a blacksmith (Penn. Agri. Rep. for 1883, 109). Two captures from the same locality, Feb. 20, 1878, and Sept. 19, 1879, are given by Fisher (Hawks and Owls, 112-1 13).

86. Falco sparverius sparverius Sparrow Hawk, "bird hawk," "little blue-backed hawk," "little chicken hawk," "little hawk," "killy hawk." Tolerably common resident, less numerous than formerly. Dr. Fisher gives 58 local captures, mostly winter dates and the season when it is rather scarce. Characteristic nesting data: Willistown, Apr. 29, 1884, five eggs taken by W. S. Hall. 
87. Pandion haliaetus carolinensis Osprey, "fish hawk," "fish eagle," "eagle." Not uncommon trans-1 ient, and of course local. There are rather indefinate intimation of it having nested along the Brandywine at one time; A. P. Lee listed it as breeding within a few miles of Oxford (Warren, Bds. Pa., 1890, 143); and Dr. Montgomery noticed a pair on several occasions during the summer of 1888 , along the former stream in East Bradford Twp. However, this species has been known to travel quite a distance in search of food and its mere presence may often be misinterpreted. I have endeavored to give both the spring and tall arrivals and departures at Berwyn vicinity:

Arrives-Apr. 5 (1908)-Apr. 21 (1893-1903); ave. 5 yrs. Apr. 14.

Departs-Apr. 29 (1913)-May 15 (I901); ave. 5 yrs. May 7 .

Arrives-Aug. 13 (1912)-Sept. 8 (1905); ave. 5 yrs. Aug. 21.

Departs-Sept. 27 (1995)-Nov. I3 (1915); ave. 4 yrs., Oct. 16.

88. Aluco pratincola Barn Owl, "monkey-faced owl," "southern barn owl," "white owl." Fairly common resident, formerly considered quite rare. The eastern part of the county the past twenty-five years, seems to have received an increasingly large number via the small creek valleys of the Delaware; becoming first numerous in Easttown, Willistown and East Goshen townships, until now it is pretty well distributed over the county. It nests usually in large isolated trees. Breeding date: East Goshen 
Twp., May 15, 1902, taken by T. H. Jackson (Kansas City Sci., v, I ; Bd. Lore, 1913, 245; and Cass., viii, 26).

89. Asio wilsonianus Long-eared Owl, "cedar owl," "hoot owl," "little horned owl," "mouse owl." Rather rare resident, common and gregarious in winter. Jackson has personally found four nests in Willistown, West Goshen and Pocopson townships; the first with five eggs, Apr. 15, I870 (Orn. and Ool., xi, 188). Pennock found a nest with eggs, Kennett Square, Apr. 7, i.906; Hughes found nests at Paoli and Valley Forge, and I have found it nesting in the Paoli barrens, 1016 and 1917.

90. A sio flammeus Shcrt-eared Owl, "day owl," "marsh owl." Tolerable common winter resident. This species will flush in grass fields and have been shot in the fall by hunters. Josiah Hoopes reported colonies in his nurseries at West Chester, about I866, and I890-1891 (Stone, Bd. E. Pa. and N. J., 90). The following nigration records are from all sources within the county:

Arrival-Oct. 27 ( I 889)-Dec. 8 (1886); ave. 8 yrs., Nov. 18.

Departure-Mar. 5 (1887)-Apr. I8 (1888); ave. 7 yrs., Mar. 22.

91. Strix varia varia Barred Owl, "hen owl," "hoot owl," "rain owl." Rare winter resident according to available data, though Michener and Pennock intimates that it is a resident. Robert P. Sharples mentions one killed recently that he believed nested in an old tree in the Bower's paper mill woods near West Chester, and Harry Wilson 
mounted a specimen said to have been shot from a nest in a pine, in a yard about a mile from West Grove. However, the less than a dozen records of capture, mostly by Warren and Fisher; are between Oct. 28 (1889) and Jan. 20 (I883).

92. Scotiaptex cinerea Great Gray Owl. Straggler. Dr. Warren records a specimen taken in midwinter, some time prior to 1870 , by $\mathrm{H}$. B. Graves, (Bds. Pa., 1890, 152).

93. Cryptoglaux acadia acadia Saw-whet Owl, "little owl." Rare winter visitant, Aug. 30 (1879) to Dec. II (1913). Dr. Warren offers the following records of its capture: Aug. 30, 1879; Nov. Io, 1883 (2) ; Sept. 20, 1884; two records of it being found dead, a male at Berwyn, Nov. 22, 1912 (No. 999, coll. F. L. B.) ; and Westtown, Dec. Ir, 1913, now in Westtown Boarding School museum (Thomas, Cass. xvi, 54); also another date for the latter place, Dec. 7, 1913 (Carter, Ibid. xvii, 54), and a captive by T. H. Jackson at West Chester.

94. Otus asio asio Screech Owl, "barn owl," "gray owl," "little bird owl," "little red owl," "mottled owl," "red owl," "screech owl," "sparrow owl." Common resident, by far the most abundant and regularly distributed species of the Striges. Eggs usually deposited Apr. I to 15.

95. Bubo virginianus virginianius Great Horned Owl, "boofer," "booby owl," "cat owl," "chicken owl," "hooter," "hoot owl," "woomer." Resident, rather rare and local in the eastern part of the county within the past few years where it was formerly common. I have no record of it ever having nested 
on the South valley hills, although it is usually attracted by heavy timber. It has been found breeding most often in the townships of Willistown, East and West Goshen, East Bradford, Thornbury, Pocopson, Birmingham and Highland; the vicinity of Kennett Square and Oxford. T. H. Jackson took his first set of eggs of this species on Feb. 22, 1868. Since then he has taken some twenty sets, and with the single exception of one set of three, the complement consisted of two eggs; the dates ranging from Feb. I to Mar. 3; all open nests, 20 to 90 feet up (Orn. and Ool., I 886, 85; Kan. City Sci., $v, 2)$. C. J. Pennock found nine open nests and five in hollow trees, and the earliest date for a full set was Feb. 15 (Cass., vi, 54).

96. Nyctea nytea Snowy Owl, "snow owl," "white owl." Rare winter visitant. Warren took two in the winter of 1879 , and Fisher gives another record, Dec. 14, 1886. Jackson relates an instance of this bird perching upon the gilded ball of the court house at West Chester, in broad daylight (Kas. City Sci., v, 3). Montgomery states that a few are shot every severe winter and that he has seen such specimens in the flesh. During the winter of 1902, one was observed flying over the Sharples Separater Works in West Chester, and perched on a nearby chimney, where it was shot (Sharples MS.).

97. Coccyzus americanus americanus Yellow-billed Cuckoo, "couk," "Indian hen," "kow bird," "rain bird," "rain crow." Tolerable common summer resident. June 15 is the average date for a 
complete set of eggs. My Berwyn dates for arrival and departure:

May 3 (1896)-May 26 (1900); ave. 1o yrs. May 17.

Aug. 29 (1896)-Oct. 5 (1895); ave. 10 yrs. Sept. 14 .

98. Coccyzus erythrophthalmus Black - billed Cuckoo, "kow bird," "rain bird," "rain crow." Not common summer resident. Arrival, May 9 (1915)-May 25 (1908); ave. 5 yrs. May 19; departure, Sept. 22 (1906). I have found nests with incubated eggs on June 15, 1885: Aug. 6, 1886; July 15 and $28,1887$.

99. Ceryle alcyon Belted Kingfisher, "kingfisher," "rattler." Not common summer resident; resident in open winters. In point of numbers, this is one of our scarcest birds though always conspicuous. Indeed it is possible for a single individual in the course of a year or two, to practically exterminate it over a considerable area; a demonstration of this occurred near Berwyn a few years since, in the interest of a trout pond.

100. Dryobates villosus villosus Hairy Woodpecker, "sapsucker." Tolerable common resident, somewhat local in distribution. Montgomery and Sharples found it only as a winter visitant. Phillips took a set of eggs in Kennett Twp. Apr. 20, 1868 (F. and S., vi, 57); I have found it breeding in Tredyffrin Twp. on several occasions, and it is also reported nesting in Willistown (Hall, Orn. and Ool., ix, 137); Oxford (Burn MS.), and the Welsh mountain region (Hunt MS.). 
IOI. Dryobates pubescens medinus Downy Woodpecker, "sapsucker." Common resident. During the winter of 1903-4, it was entirely absent from the South Valley hills in the vicinity of Berwyn, and did not become common until Mar. 19, 1904. It begins drilling for nest as early as April 15, and the eggs are deposited by May Io.

102. Sphyrapicus varius, varius Yellow-bellied Sapsucker, "sapsucker." Tolerable common transient, and according to Warren, an occasional winter visitant. Pennock has a Kennett Square record for Dec. 12, 1901. Montgomery has found it in April, and from Sept. 28 to Nov. 21. The combined county data gives the following results:

Feb. I4 (I90I)-May 24 (1908); ave. 7 yrs. Apr. 18.

Oct. 4 (I887-1913)-Dec. I2 (I90I); ave. 9 yrs. Oct. 19.

103. Phlocotomus pileatus pileatus Pileated Woodpecker, "Indian iıen." Straggler. A former resident, now extinct locally as such. In Barnard's time it was very rare; Michener recorded it as almost extinct, and in his later list announced that this noble and once common bird had disappeared with the forest which had afforded it protection. A straggler was taken about 1878 (Warren, Bds. Pa., I 890, I 7 I).

104. Melanerpes erythrocephalus erythrocephalus Red-headed Woodpecker, "red-head woodpecker." Tolerable common summer resident; occasional resident, especially in the Chester valley (Cass., vii, 10). Breeding date: Chester valley, May 19, 1904, 
four eggs heavily incubated. Berwyn data on migration.

Arrives-Apr. 15 (1912)-May 6 (1905-1910); ave. 12 yrs., May 1.

Departs-Oct. 9 (1899)-Nov. 12 (1901$1902)$; ave. 9 yrs., Oct. 25.

105. Centurus carolinus Red-bellied Woodpecker. Rather rare winter visitant, mentioned by all our list-makers. Phillips found it at Kennett Square, Oct., 1871 (F. and S., vi, 148); two specimens were taken by Rhoads at Kimbleville, Jan. I, I880 and Dec. 8, 1881 (Stone, Bds. E. Pa. and N. J., 96); and Warren has taken three in ten winters (Bds. Pa., 1890, 174).

106. Colaptes auratus luteus Northern Flicker, "flicker," "golden-wing," yellowhammer," "yellowshaft flicker." Common summer resident, occasional resident; the most abundant representative of its family. Nidification begins Apr. 15-25, average date for complete set May 26 (Burns, Mon. of the Flicker, Wils. Bull., No. 3I). Migration at Berwyn :

Arrival-Feb. 2 (1889)-Apr. 6 (1899); ave. 27 yrs., Mar. 15.

Common-Feb. 17 (1888)-Apr. 23 (1899); ave. 24 yrs., Mar. 23 .

Bulk-Sept. I3 (1899)-Oct. 19 (1 893-1 894); ave. 12 yrs., Oct. 1 .

Last-Oct. 7 (1915)-Dec. I I (1900); ave. 20 yrs., Oct. 29.

107. Antrostomus vociferus vociferus Whip-poorwill, "whipper-will," "whipper-ca-loo." Not com- 
mon summer resident, formerly common. Nesting data: Parkesburg, Mav 20, 1885, collected by J. H. Matlack (Sharples MS.). The migration data for spring arrival is from all available sources, and the fall departure from my Berwyn notes:

Arrival-Apr. 25 (1900-1913)-May 9 (1912); ave. 12 yrs. May 1.

Departure-Sept. I4 (1896)-Oct. I9 (1887); ave. 4 yrs. Sept. 29.

108. Chordeiles virginianus Nighthawk, "bird hawk," "bullbat," "whipper-will." Tolerable common summer resident, rather local in character. Breeding record: Paoli barrens, June 9, 1900, two young (Bailey, Cass., v 221). Migration records from all sources:

Arrival-May 3 (Iyoo)-May 27 (1903); ave. 16 yrs. May I 4 .

Depart.-Sept. 16 ( I 890)-Oct. 9 (1904); ave. 4 yrs. Sept. 23.

109. Chatura pelagica Chimney Swift, "chimney bat," "chimney bird," "chimney swallow," "chimney sweep," "swallow." Common summer resident. Nesting date: Berwyn, June 1, 1914, five eggs, collection of F. L. B. Berwyn migration records: Arrives-Apr. I8 (I8gI)-May I (I913); ave. 33 yrs. Apr. 25.

Common-Apr. 19 (1891)-May 3 (1913); ave. 28 yrs. Apr. 27.

Bulk dep.-Aug. I I (I9I6)-Oct. I I (1900), ave. 13 yrs. Sept. 15.

Last-Sept. I3 (1905)-Oct. 18 (1902); ave. 19 yrs. Oct. 1. 
64 The Ornithology of Chester County

I10. Archilochus colubris Ruby-throated Hummingbird, "hummingbird." Tolerable common summer resident. Nest and two eggs, Berwyn, June 10, 1899. Also Berwyn migration data:

Arrives-May II (1886)-May 22 (1917); ave. 17 yrs. May 15.

Departs-Aug. 24 (1913)-Oct. 9 (1887); ave. 17 yrs. Sept. 5 .

III. Tyrannus tyranus Kingbird, "beebird," "kingbird," "tweet," "tyrant flycatcher." Tolerable common summer resident. My Berwyn migration data may average a few days later than that of the southern parts of the county.

Arrival-Apr. 20 (1895)-May 20 (1917); ave. 18 yrs. May 5.

Common-Apr. 25 (1895)-May 27 (1917); ave. Io yrs. May ıo.

Departure-Aug. 24 (1905)-Sept. Io (1904); ave. II yrs. Sept. 2.

I12. Myiarchus crinitus Crested Flycatcher, "flycatcher," "great-crest," "snake bird." Common summer resident. Nesting data: Berwyn, June 4, I 893, five eggs.

Berwyn:

Arrival-Apr. 17 (1913)-May 8 (1909); ave. 26 yrs. May 1.

Common-Apr. 19 (1894)-May 19 (1913); ave. 22 yrs. May 9.

Departure-Aug. 29 (1902)-Oct. 7 (18951897); ave. 13 yrs. Scpt. I5.

I 3. Sayornis phobe Phœbe, "beambird," "bridgebird," "phœbebird," "pewee," "pewit." 


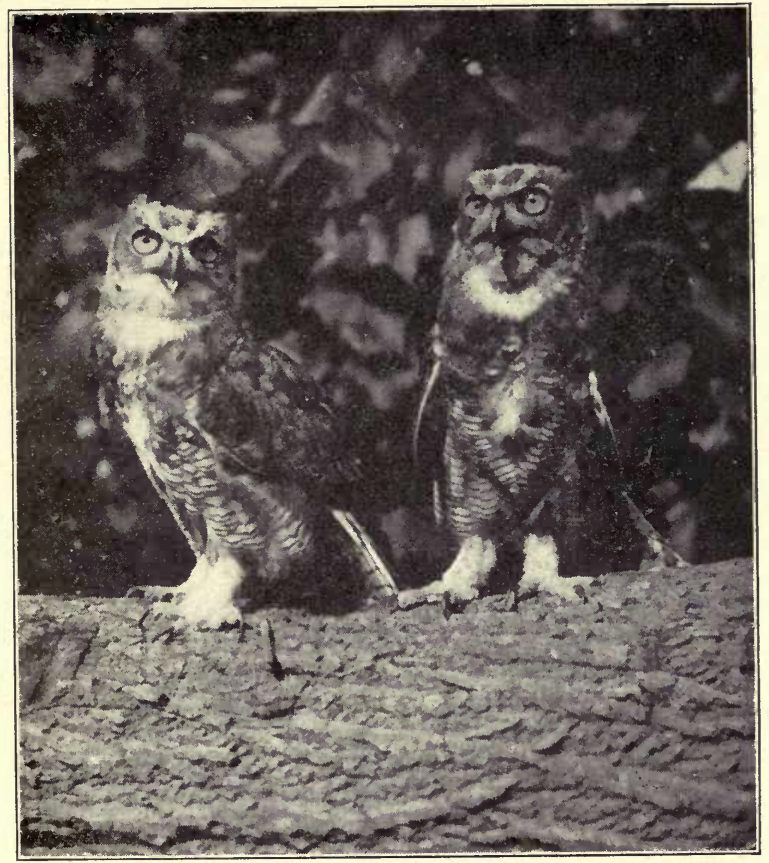

Photo by T. H. Jackson

GREAT HORNED OWLS FIFTEEN WEEKS OLD 


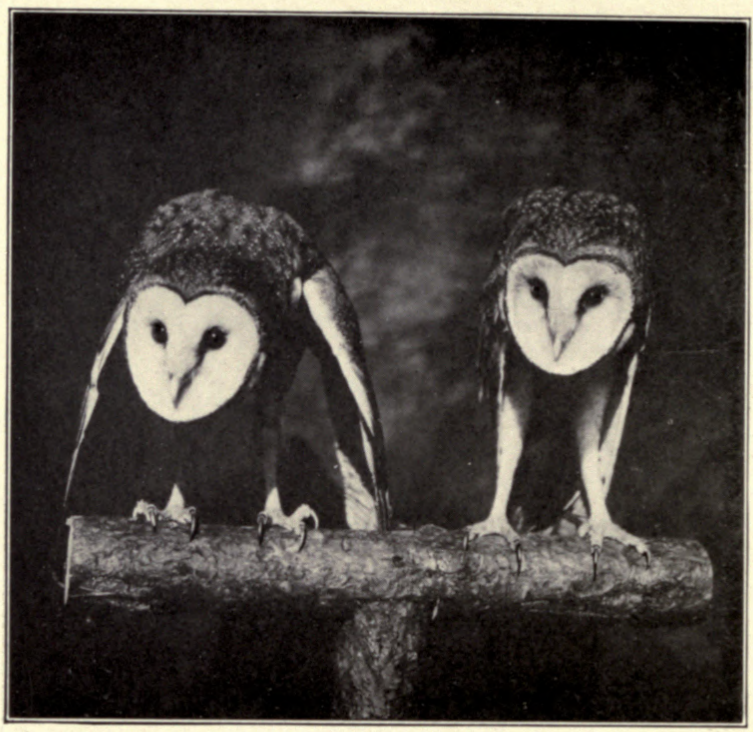

Photo by T. H. Jackson

BARN OWLS TEN WEEKS OLD 


\section{Annotated List}

Common summer resident, occasional in winter. Pennock saw one on Dec. 27, 1883, another Jan. 9, 1884; Dr. Warren saw C. D. Wood skinning a specimen said to have been shot at Spring City, Jan. 22, I883 (Bds. Pa., I5I); and J. D. Carter in his West Chester-Coatesville bird census, 190103, has thrice reported an individual on Dec. 25 (Bd. Lore, iv, 29; v. 17). Nidification begins about Apr. 25; average date for first complete set, May 5. Berwyn:

Arrival-Mar. 2 (1909)-Apr. 13 (1906); ave. 27 yrs. Mar. 25.

Common-Mar. 17 (1898)-Apr. 14 (1896); ave. 14 yrs. Apr. 3.

Departure-Oct. I (1885-1897)-Oct. 31 (1889); ave. 16 yrs. Oct. I 4.

I 14. Nuttallornis borealis Olive-sided Flycatcher. Rare transient. Given by Michener. Warren states that a few specimens have been taken at irregular periods, and that C. D. Wood took a specimen near Coatesville, May I, 1864. Stone reports that one was taken along the Brandywine, near Mortonville, May 4, 1898, and Thomas observed one at Kennett Square, May 3, 1909.

115. Myiochanes virens Wood Pewee. Common summer resident. Nesting data: Chester Valley, May 19, 1904; three eggs.

Berwyn:

Arrival-May 3 (1896)-May 22 (1917); ave. II yrs. May 13.

Common-May II (1904)-May 30 (1907. 1917); ave. 6 yrs. May 21. 
Departure-Aug. 24 (1907)-Sept. 26 (1889); ave. 5 yrs. Sept. 7 .

116. Empidonax flaviventris Yellow-bellied Flycatcher. Rare transient; probably more regular than supposed, as it is mentioned by all our list makers. Warren took four specimens Sept. 22-30, 1880, and Montgomery secured three or four. The other records are: Berwyn, Sept. 19, 1898 (No. 686, coll. F. L. B.) ; Westtown, May 6, 1904 (Linton), and Kennett Square, June 2, 1907 (Pennock). Barnard informs us that it arrives May 8 to 14 .

117. Empidonax virescens Acadian Flycatcher, "hick-up." Tolerably common summer resident; in late years becoming more localized and scarcely ever found on the higher hills. Average date for complete set of eggs at Berwyn, June 9.

Berwyn:

Arrival-May 7 (1891-1 895)-May 26 (1900); ave. 15 yrs. May 15 .

Common-May 14 (1901-1905)-May 31 (1910); ave. II yrs. May 22.

It has been observed as late as Sept. 20.

118. Empidonax trailli alnorum Alder Flycatcher. Rare transient. Dr. Michener of course followed Baird in calling this species E.trailli Traill's Flycatcher, and appears to be the only one, with the exception of Dr. Warren; who has obtained it in the county. There are no recent records.

119. Empidonax minimus Least Flycatcher, "chebec." Tolerably common transient.

Berwyn:

Vernal arriv.-Apr. 28 (1915)-May 7 (1917); 
ave. 6 yrs. May 3.

Vernal depart.-May 7 (1907-1909)-May 16 (1905); ave. 6 yrs. May II.

Dr. Montgomery never observed it in the fall, and I have but one fall capture at Berwyn, Oct. 15, 1889.

120. Otocoris alpestris alpestris Horned Lark, "field lark," "skylark." 42 Tolerably common winter visitant; gregarious and irregular. Barnard gives its arrival as Dec. 5 to 22 ; Carter found many individuals on Dec. 25, 1901-03; Pennock at Kennett Square on Jan. 5, 1912; Fowler at Cheyney, Feb. 12, 1907; Pennell at Downingtown on Feb. 23, 1902, and Feb. 20-26, 1903; and the latest date in which it has been seen at Berwyn is Mar. 16 ( 1896 ).

I21. Cyanocitta cristata cristata Blue Jay, "jay," "jay-bird." Common resident. Not present at Berwyn during the winter of $\mathrm{i} 903-04$, nor at Westtown winter of 19ro-1 I. Nesting data: Devon, Apr. 25, 1915, six eggs. An interesting flight of this species occurred over my home between 7.30 and 10.30 A. M. on Oct. 7, 1917. The birds were in flocks of from two to forty individuals, flying with surprising rapidity southwest in one track at an estimated elevation of 300 feet above the hill. These flocks were sometimes many minutes apart and the birds could be occasionally heard uttering the characteristic "keck."

122. Corvus corax principalis Northern Raven. Formerly resident, now extinct. Very rare (Barnard); resident, now very rare or extinct (Mich- 


\section{The Ornithology of Chester County}

ener).

123. Corvus brachyrhynchos Crow. Common resident, abundant in winter. A famous roost located on the North Valley hills near Diamond rock, was visited as early as 1889 by the writer, and in 1899, 1900 and 1901 by Dr. W. E. Rotzell. It occupied probably ten acres and shifted from place to place as the birds were disturbed. Flight lines have shown that the Crows sought this roost from Audubon on the Perkiomen, Port Kennedy, Norristown, Conshohocken, Bryn Mawr, Radnor, Devon, Wawa, Westtown and League Island.

Prior to 1890 , another roost was situated on the North Valley hills near Coatesville. T. H. Windle estimated the number at from 30,000 to 50,000 . In 1895, this roost was on the south ridge, between Coatesville and Pomeroy; later shifted back to the north ridge, which was cccupied for several winters, according to $H$. E. Stone. Crows returned to this roost from Kennett Square, Timicular, Mortonville and probably from Lenape: while a number of other flight-lines converged from the north and west ( Coggins, Cass., vii, 34, 36-38 and map). Nidification commences as early as Mar. 20 in open seasons, and the average date for a complete set is Apr. I 5.

124. Corvus ossifragus Fish Crow, "crow." Tolerably common resident, formerly quite rare or absent except in the southern part of the county. Some years prior to 1888, J. H. Matlack took a set of eggs somewhere along the Brandywine (Warren, Bds. Pa., 162). On Mar. 6, I891, Frank H. Stauffer, of Berwyn, found a dead male in his yard and 
presented it to me (No. 205, coll. F. L. B.), and I found my first nest and eggs on May II, 1899, (Osprey, iv, 33), and it became fairly well distributed, though rather solitary, until the chestnut blight destroyed the tall timber in which it was accustomed to nest.

125. Sturnus vulgaris Starling, "blackbird," "stare." Common resident, gregarious and most abundant in winter. First observed in the Chester valley opposite Berwyn, Jan. 5, 19II, and a male secured on Feb. 2 (No. 983, coll. F. L. B.) is probably the first specimen for the county, and it nested the same year at Bacton (Wils. Bull., 90, 289). First observed at West Chester, Dec. 3, 1911 , by T. H. Jackson (Auk, xxix, 243); Phœnixville, June 9, 1912, by L. S. Pierson; Westtown, June 3, 1912, by S. C. DeHaven, and Kennett Square, Mar. 8 , 1913, by C. A. Thomas (Cass., xvi, 49 , and xviii, $56)$.

126. Dolichonyx oryzivorus Bobolink, "reedbird." Passably common transient and rare summer resident. Montgomery says that it is found almost exclusively along the Brandywine in spring, but in the fall it is frequently met with on the uplands in clover fields. Dr. Warren hints that nests have been found on one or two occasions (Bds. Pa., 1890, 206); Dr. Trotter found several pairs at Cheyney apparently nesting in the fields (Auk, xxxi, 400), and on June 3, 1917, R. P. Sharples, G. L. Eadie and the writer observed a pair in a meadow of the Chesterbrook farm, near Berwyn; evidently nesting.

Spring arrival-Apr. 27 (1908)-May 15 
(1914); ave. 28 yrs. May 7.

Fall arrival-Aug. 4 (1886)-Sept. 25 (1890); ave. 8 yrs. Aug. 28 .

127. Molotherus ater ater Cowbird, "cow blackbird," "cowpens bunting," "lazybird," "little blackbird." Tolerably common summer resident. Dr. Warren states that Harry Garrett of Willistown had noted it as an occasional resident, and I once observed it at Berwyn on Jan. 17, 1913. This species builds no nest, but lays its eggs in other birds' nests where the young are hatched and reared by the foster parents.

128. Agelaius phoniceus phoniceus Red-wing. ed Blackbird, "red-wing," "swamp blackbird," "swampy." Common summer resident, gregarious, and most abundant during migrations. Nesting data: Berwyn, May 25, 1889, four eggs taken by W. E. Rotzell. The Kennett Square, Westtown and West Chester migration data for first arrival average several days earlier than that of Berwyn which I give below:

First arrival-Feb. 17 (1909)-Apr. 10 (1886); ave. 29 yrs. Mar. 15.

Bulk arrival-Mar. 4 (1908)-Apr. 24 (1902); ave. 18 yrs. Mar. 25.

Bulk departure-Sept. 30 (1916)-Oct. 25 (I9II) ; ave. 6 yrs. Oct. I4.

Last seen-Sept. 15 (1902)-Nov. 5 ( 1888); ave. 7 yrs. Oct. 26.

129. Sturnella magna magna Meadow Lark, "field lark," "meadow lark," "yellowbreast." Common resident, gregarious and rather local in winter. 
Dr. Montgomery says he can corroborate the fact noticed by other observers that in the cold season, it always migrates to a certain extent by leaving the higher ground to collect in the valleys. J. H. Matlack found a nest containing eight young and one egg, June 3,1879 ; a most unusual number (Ool., $\mathrm{v}, 43$ ).

I30. Icterus spurius Orchard Oriole, "hangbird," "hangnest," "oriole," "yellow hangbird." Tolerable common summer resident. Nesting data: Berwyn, June 1, 1888, four eggs.

Berwyn:

Arrival-Apr. 30 (1898)-May 15 (I9II); ave. 23 yrs. May 6.

Common-May 4 ( 1895 )-May 13 (1902-19031904-1905); ave. I I yrs. May II.

Departure-Aug. 23 (1899)-Sept. 9 (I901); ave. 14 yrs. Aug. 30.

I3I. Icterus galbula Baltimore Oriole, "firebird," "golden hangnest," "golden oriole," "hangbird," "hangnest," "yellowbird." Common summer resident. Nidification begins about May 25.

Berwyn:

Arrival-Apr. 22 (I909)-May II (1903); ave. 27 yrs. May 5 .

Common-May 7 (1899)-May 15 (1900); ave. I 4 yrs. May Io.

Departure-Aug. 24 (1913)-Sept. 14 (1914); ave. 17 yrs. Aug. 28.

132. Euphagus carolinus Rusty Blackbird, "Carolina blackbird." Not common transient, occasional winter visitant. J. D. Carter has recorded a single 
individual in his West Chester-Coatesville Christmas census, 1901-02-03 (Bd. Lore).

Spring arrival-Feb. 16 (1909)-Mar. 19 (1905); ave. 9 yrs. Mar. 5.

Fall arrival-Oct. 24 (1915)-Nov. 22 (1896); ave. 3 yrs. Nov. 8.

133. Quiscalus quiscula, quiscula ${ }^{43}$ Purple Grackle, "blackbird," "crow blackbird." Abundant summer resident; not rare resident in mild winters. Gregarious, nesting in colonies and gathering in immense numbers previous to the autumnal flight. Nidification begins Apr. 15; average date for complete set, Apr. 26. Berwyn data on the migration of this bird is unusuallv complete.

Arrival-Jan 7 (1890)-Mar. 16 (1885); ave. 33 yrs. Feb. 27.

Bulk arriv.-Feb. I3 (1890)-Mar. 27 (1885); ave. 32 yrs. Mar. 9 .

Bulk depart.-Sept. 24 (1891)-Nov. II (I 889 ); ave. 25 yrs. Oct. 20.

Last seen-Oct. 6 ( 1887$)$-Dec. 24 (1889); ave. 32 yrs. Nov. 5 .

134. Quiscalus quiscala aneus Bronzed Grackle. Straggler. Dr. Montgomery took a specimen in East Bradford, Apr. 30, 1889, and Dr. Chapman found one closely approaching this form in a series of skins taken in the breeding season in Chester county by Dr. B. H. Warren and G. W. Roberts.

135. Pinicola enucleator leucura Pine Grosbeak. Rare winter visitant; occurs only in the most severe weather. Listed by Michener, Warren and Pennock. 
136. Passer domesticus hostilis British House Sparrow, "English sparrow," "house sparrow" "town sparrow." Abundant resident. Introduced in Chester county about 1875 , when six birds were brought to West Chester from Philadelphia (Barrow, English Sparrow in N. A.) ; in 1879 , according to Dr. Warren, it had already become abundant and a pest.

137. Carpodacus purpureus purpureus Purple Finch, "hempbird," "red sparrow." Tolerably common transient and irregular winter visitant. Dr. Warren examined twenty-one specimens taken during the latter part of March, throughout April and from May I to I5 (Bds. Pa., I83). Dr. Montgomery personally observed it only in the year 1887 , from Apr. 26 to May 9. A few have been observed on Christmas day, I9I I-I4-15, by Dr. Ehinger, especially near West Chester, and I have a single specimen taken in winter, Feb. 8, 1907 (No. 906, coll. F. L. B.).

Autumnal migr.-Oct. 8 (1916)-Nov . II (1897); ave. 7 yrs. Oct. 24.

Vernal migr.-Apr. 25 (1913)-May 9 (1887); ave. 9 yrs. May 2.

138. Loxia curvirostra minor Crossbill. Not common winter visitant, and occasional summer straggler. Mentioned by Michener, Warren and Pennock; the latter reports it at Kennett Square, in January, 1900 (Abst. D. V. O. C., iv, 2). Dr. Montgomery found it near West Chester on one or two occasions, and Josiah Hoopes collected it quite frequently in the Hoopes Brothers and Thomas 
nurseries, West Goshen Twp. On June 16-17, 191 I, Pennock and Carter observed two adults and two juveniles in a scattered growth of pitch pines, the barrens of the extreme southwest corner of the county, bordering Maryland (Auk, xxix, 245).

139. Loxia leucoptera White-winged Crossbill. Rare winter visitant. Audubon states that he obtained some specimens during winter along the chilly shores of the Schuylkill (Orn. Biog.); Barnard obtained it in December, 1854; and Montgomery reported two at West Chester, Jan. 28, 1900 (Abst. Proc. D. V. O. C., iv, 2). There are also two sight records: Jan. 27, 1900, at Kennett Square (Pennock MS. communicated by Thomas); and Jan. 12, 1917, at Berwyn, by the writer.

140. Acanthis linaria linaria Redpoll. Irregular winter visitant. Both Barnard and Michener considered it very rare. Dr. Warren and a friend obtained 150 specimens during the winter of $1878-79$, although for fifteen years prior to this it had not been seen, at least in any numbers (Bds. $\mathrm{Pa}$., 185 ). It has also been reported from West Chester, Mar. 24, 1888, and Feb. 14, 1899, by Montgomery; Feb. 17, 1907, by Sharples and Jackson; and Mar. 5, 1914, by Roberts; Downington, Feb. 24, 1902, by Pennell; Kennett Square, Dec. 25, 1906, Feb. 25 and Mar. 13, 1907, by Pennock; Mar. 3, 1914, by Thomas; and Paoli, Feb. 16, 1907, by Redfield; from a single individual to flocks of fifty.

141. Astragalinus tristis tristis Goldfinch, "letticebird, "saladbird," "sunflowerbird," "thistlebird," "wild canary," "yellowbird." Common resi- 
dent, though many migrate in severe winters. Nesting data: Berwyn, Aug. 12, 1889, four eggs.

142. Spinus pinus Pine Siskin. Irregular winter visitant and vernal transient. I observed a flock of twenty-five at Berwyn, Apr. 30, 1909.

Arrival-Dec. 25 ( 1913 )-Feb. 5, ( 1888 ).

Departure-Apr. 30 (1909)-May 15 (1912); ave. 6 , records May 4.

143. Plectrophenax nivalis nivalis Snow bunting. Irregular winter visitant in small flocks. Considered rare by Barnard and Michener. Pennock noted it in the winter, of $1870-71$ and 1900 , and secured three specimens in 1886 , near Kennett Square. Observed at Downingtown, Feb. 23, 1902, by Pennell; Berwyn, Feb. 17, 1905, by Burns; West Chester, Mar. 2, 1914, by Ehinger; in flocks of not more than thirty birds.

144. Calcarius lapponicus lapponicus Lapland Longspur. Rare winter visitant. Michener gave it as very rare. Not in Barnard's list, but according to Pennock, his cabinet contained a specimen taken in the county later than the publication of his list.

145. Poocates gramineus gramineus Vesper Sparrow, "field sparrow," "grass finch," "ground chippy," "snakebird." Tolerably common summer resident, occasional resident. Nesting data: Berwyn, June IO, I885, four eggs.

Berwyn:

Arrival-Mar. 15 (1898)-Apr. 20 (1891); ave. 20 yrs. Apr. 5 .

Common-Apr. 4 (1902)-May 4 (19061911 ) ; ave. 15 yrs. Apr. 20. 


\section{The Ornithology of Chester County}

Departure-Oct. 9 (1890-1 895-1 899-1 896)Dec. 22 (1887); ave. 7 yrs. Oct. 25.

146. Passerculus sandwichensis savanna Savannah Sparrow. Transient; Michener, Warren and Pennock consider it common, while Montgomery found it abundant in spring and fall. At Berwyn it is not at all common, and migration records from all sources all too scanty.

Spring arrival-Mar. 28 (1889)-Apr. 18 (1891-1915) ; ave. 8 yrs. Apr. 12.

Spring departure-Apr. I3 (1886)-May 9 (189I); ave. 5 yrs. Apr. 21.

Fall date, Nov. 4, 1902.

147. Ammodramus savannarum australis Grasshopper Sparrow, "ground chippy," "yellow-winged bunting," "yellow-winged sparrow." Tolerably common summer resident; rather local, breeding in small colonies in grass fields. Nesting data: June 4, 1884, Willistown, four eggs; taken by W. S. Hall.

Berwyn:

Arrival-Apr. 21 (1893)-May 3 (1917); ave. 12 yrs. Apr. 28.

Common-May 8 (1909-16)-May 21 (1913); ave. 7 yrs. May II.

Departure-Oct. 6 (1905)-Oct. 7 (1917); ave. 2 yrs. Oct. 7.

148. Passerbulus henslowi henslowi Henslow's Sparrow. Rare transient, and so listed by all authorities. I have a female taken at Berwyn, Oct. 23, 1896 (No. 615, coll. F. L. B.). Hunt observed six pairs at Cupola, Apr. 24, shot one on the 


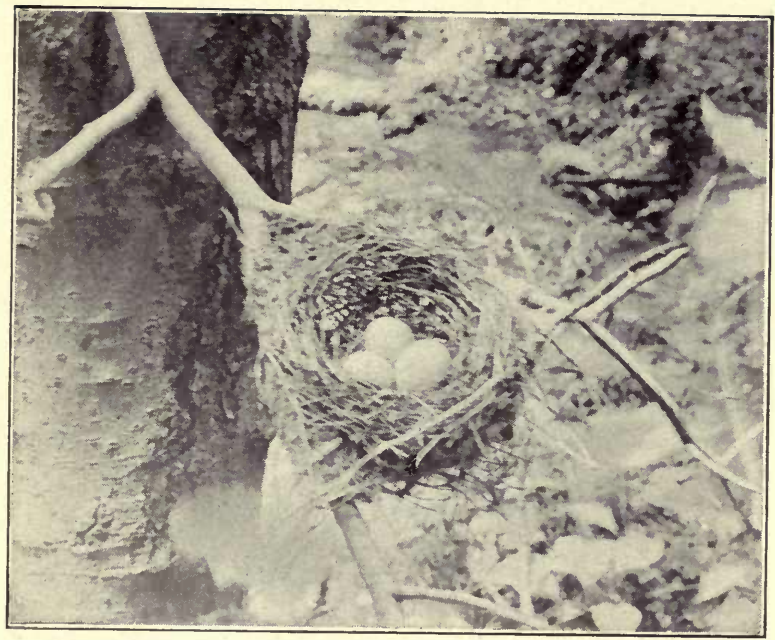

Photo by T. H. Jackson

ACADIAN FLYCATCHER NEST AND EGGS 


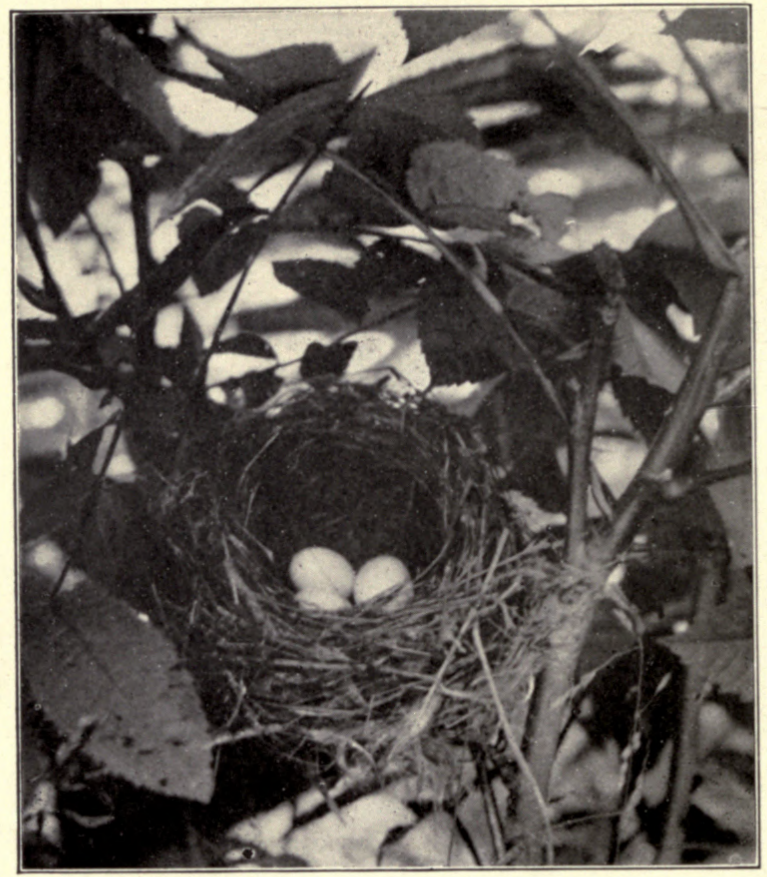

Photo by T. H. Jackson

INDIGO BUNTING NEST AND EGGS 
26, and it was last seen on May 8, 1914 (Auk, xxi, 386). Roberts reports a small flock near New Garden, Oct. II, I9I4.

149. Zonotrichia leucophrys leucophrys Whitecrowned Sparrow. Rare transient. In submitting the migration data from all sources, the possibility of error in sight records is believed at a minimum, all being experienced observers; and all records as far as I know are for solitary individuals.

Spring arrivals-Apr. 30 (1907)-May 20 (1892) ; ave. 12 yrs. May ro.

Fall arrival-Oct. 6 (1905)-Oct. 18 (1890); ave. 5 yrs. Oct. IO.

150. Zonotrichia albicollis White-throated Sparrow, "peabody bird." Abundant transient, and occasional winter resident. Berwyn migration data:

Spring arrival-Mar. 6 (1906)-Apr. 16 (1898); ave. 13 yrs. Mar. 27.

Spring departure-Apr. 27 (1902-1907-1911)May 23 ( 1905 ); ave. 12 yrs. May 12.

Fall arrival-Sept. 24 (1913)-Nov. I (1900); ave. 18 yrs. Oct. 7 .

Fall departure-Oct. 18 (1903)-Dec. 20 (1900); ave. 15 yrs. Nov. 4.

151. Spizella monticola monticola Tree Sparrow, "winter chippy." Tolerable common winter resident, often associating with the Junco.

Berwyn:

Arrival-Oct. I7 (1896)-Dec. I I (1886); ave. 8 yrs. Nov. 2.

Common-Oct. 20 ( 1894)-Dec. I I ( I 886); ave. 8 yrs. Nov. 18 . 
Departure-Mar. 16 (1901)-Apr. 21 (1887); ave. 17 yrs. Apr. 9.

152. Spizella passerina passerina Chipping Sparrow, "bush sparrow," "chippy," "chip sparrow," "hairbird," "honeysucklebird," "house sparrow," "tit," "tree sparrow." Abundant summer resident. Nidification commences May 5; average date for complete set, May 15 .

Berwyn:

Arrival-Mar. 2 (I909)-Apr. 18 ( I 89I); ave. 32 yrs. Mar. 30.

Common-Mar. 29 (1907-1914)-Apr. 29 (1891) ; ave. 29 yrs. Apr. 10.

Bulk departure-Sept. 20 (I906)-Oct. 2 I (1902) ; ave. 8 yrs. Oct. 8.

Last seen-Sept. 29 ( I 898)-Oct. 28 (1891); ave 19 yrs. Oct. 14 .

153. Spizella pusilla pusilla Field Sparrow, "bush sparrow," "field chippy," "field sparrow," "ground chippy." Abundant summer resident, occasional resident. Average date for set of eggs, May 18.

Berwyn:

Arrival-Mar. 6 (1906)-Apr. 15 (1887); ave. 30 yrs. Mar. 29.

Common-Mar. 24 (1903)-Apr. 29 (1891); ave. 30 yrs. Apr. 5 .

Bulk departure-Sept. 26 (1904)-Oct. 23 (1895); ave. 13 yrs. Oct. 13.

Last seen-Oct. 6 (1904)-Nov. 29 (1887); ave. 20 yrs. Oct. 22.

154. Junco hyemalis hyemalis Slate-colored Junco, 
"black snowbird," "snowbird." Abundant winter resident. gregarious. This species is undoubtedly the most abundant of all our native birds in winter. Berwyn:

Arrival-Oct. 4. (1897)-Dec. 3 (1887); ave. 28 yrs. Oct. 22.

Common-Oct. 6 (1908)-Dec. 27 (1890); ave. 24 yrs. Oct. 28.

Bulk departure-Apr. 4 (1892)-Apr. 19 (1904); ave. 13 yrs. Apr. 12.

Last seen-Apr. 4 (1892-1913)-Apr. 30 (1890) ; ave. 26 yrs. Apr. I8.

155. Melospiza melodia melodia Song Sparrow, "bush sparrow," "cheer-up, cheer-up for Easter," "ground chippy," "ground sparrow," "song sparrow." Tolerable common resident and abundant summer resident. Nidification begins as early as Apr. 30; average date for complete set, May 16.

Berwyn:

Bulk arrive-Feb. I I (1890)-Mar. 30 (1887); ave. 19 yrs. Mar. 7.

Bulk depart-Oct. 9 (1895)-Dec. 7 (1886); ave. 7 yrs. Nov. 12.

156. Melospiza lincolni lincolni Lincoln's Sparrow. Rare transient; Dr. Michener says extremely rare. Dr. Warren has killed several during migrations, near West Chester; two early in May, one late in September, and one early in October; and R. P. Sharples secured a male, Sept. 18, 1900, at the same place, and the skin is now in his collection.

157. Melospiza georgiana Swamp Sparrow. Regular transient and rare summer resident; some- 
what local and not gregarious. Pennock states that a nest with eggs was taken near Kennett Square in 1885; and Sharples has found it every year in a swamp at Eachus's mill, near West Chester; and believes it is a summer resident. Migration records from all available resources:

Spring arrival-Mar. 23 (1886)-Apr. 30 (1905); ave. 9 yrs. Apr. 23.

Spring departure-May 9 (1891-1897)-May 13 (1894); ave. 3 yrs. May 10.

Fall arrival-Oct. 5 (1890)-Oct. 18 (1909); ave. 3 yrs. Oct. 10.

158. Passerella iliaca iliaca Fox Sparrow, "foxcolored sparrow," "hedge sparrow." Tolerably common transient; occurs usually in small flocks.

Berwyn:

Spring arrival-Feb. 22 (1888)-Mar. 25 (1905); ave. 18 yrs. Mar. 13.

Spring departure-Mar. 9 ( 1890 )-Apr. 29 (1896); ave. 9 yrs. Apr. I1.

Fall arrival and departure-Nov. I-24.

159. Pipilo erythrophthalmus Towhee, "chewink," "chip-cherry bird," "ground robin," "jowink," "juwink," "to-wee," "thrush." Common summer resident, occasional resident. Nesting data, Berwyn, May 22.

Berwyn:

Arrival-Mar. 29 (1904)-Apr. 30 (1907), ave. 29 yrs. Apr. 17.

Common-Apr. 5 (1902)-May 5 (1901); ave. 26 yrs. Apr. 27.

Bulk depart-Sept. 27 (1893)-Oct. 12 (1894); 


\section{Annotated List}

ave. 10 yrs. Oct. 6.

Last seen-Oct. 5 (1900-1912)-Nov. 3 (1888); ave. 24 yrs. Oct. 15.

The female arrives several days later in the spring than given in the first dates.

160. Cardinalis cardinalis cardinalis Cardinal, "corn cracker," "English cockatoo," "kowbird," "rainbird," "redbird," "red jay," "red whistler," "Virginia nightingale," "winter redbird." Tolerably common resident, especially in the swampy thickets; probably more common in winter. In 1909, T. H. Jackson of West Chester, asserted that it was more common than it was twenty years ago. Nesting records from May 9 to June 12, at Berwyn.

161. Zamelodia ludiviciana Rose-breasted Grosbeak. Regular, though not common transient, and rare summer resident. Audubon found it rather plentiful in the early part of May, along the banks of the Schuylkill, twenty or thirty miles from Philadelphia (Orn. Biog.). Dr. Warren found it exceedingly abundant in the woods May II-27, 1882, and fifty specimens were taken. B. M. Everhart, also of West Chester, said that twenty-five years ago, it was a rather common summer resident and that he repeatedly found its nest, eggs and young (Warren, Bds. Pa., 199); also, according to Dr. Warren, Titus Bennett found a nest and three eggs near Deborah's rock, East Bradford Twp., about I 875 .

Berwyn:

Spring arrival-May 7 (I9II)-May 17 (1917); ave. 8 yrs. May II. 
Spring departure-May 16 (1906)-May 23 (1917).

Fall arrival and departure-Sept. 19 (1893)Oct. 5 (1905).

162. Guiraca carulea carulea Blue Grosbeak. Straggler from the south. Appears on Michener's lists, and Warren took a specimen in the lower part of the county on May Io, about 1885 (Bds. Pa., $1890,248)$.

163. Passerina cyanea cyanea Indigo Bunting, "bluebird," "blue bunting," "indigobird," "greenbird." Common summer resident. Nest with eggs May 27-Juné 18.

Berwyn:

Arrival-May 3 (1895)-May 20 (1886); ave. 16 yrs. May 12.

Common-May 6 (1897)-May 30 (1900); ave. 12 yrs. May I7.

Bulk departure-Sept. 5 (1904)-Oct. 6 (1914); ave. 6 yrs. Sept. 21.

Last seen-Sept. 30 (1906)-Dec. 3 (1914); ave. 8 yrs. Oct. 9 .

164. Spiza americana Dickcissel, "black-throated bunting," "Maybird." Formerly a summer resident, localized in the southern and eastern parts of the county. Michener considered it common, and Barnard records its arrival on Apr. 27 to May 3; Warren, in his list of $1879-80$, remarks that he found it rare and not breeding. A nest with eggs was found by Phillips, near Avondale, July 4, I871 (F. and S., vi, 67); a nest and eggs was taken from a currant bush near the county line, Eagle hotel 
(Strafford), in 1874 , by D. N. McCadden and Geo. C. Thayer (Rhoads, Cass., vii, 24); another was taken from along an osage hedge in a clover meadow, Leopard (near Berwyn) in 1876 , by my elder brothers and J. W. Sharp, Jr., and some of the endblown Bluebird-like eggs may be seen in the Sharp collection yet. Pennock states that the bird was present up to 1875 and recalls two localities where he always expected to find it present in the nesting season; one was near the village of Avondale and the other half a mile south of Kennett Square. He has frequently heard the male sing from scattered trees or bushes along the roadside but never found a nest. He first became acquainted with it about 1871 , and never knew of more than two or three pairs which always affected certain spots (Rhoads, Cass., vii, 24). A. Palmer took a specimen in the spring of 1902 (Thomas MS.).

165. Spiza townsendi Townsend's Bunting. Straggler; unique, probably the last of a decadent race. The type and only specimen known to science was taken at New Garden, May I I, I833; and the following is an extract from the diary of Dr. Ezra Michener: "This morning my friend John K. Townsend, in company with John Richards, while in quest of birds for my cabinet; shot a bunting in William Brown's cedar grove, near New Garden meeting-house, which is believed a nondescript. We have given it the provisional name of Euspiza albigula or white-throated bunting." Audubon described and figured it in his original work (Orn. Biog., ii, 1834, 183; pl. (ccc), and considered it a 
distinct species, but closely related to S.americane. This specimen remaining in the collection of Dr. Michener for twenty-four years, except for the brief time it was in the hands of Audubon; and finally presented it to the Smithsonian Institution and it is now in the U. S. National Museum.

166. Piranga erythromelas Scarlet Tanager, "black-winged redbird," "redbird," "summer redbird." Tolerable common summer resident. Nesting data: Berwyn, June I, 1900; three eggs.

Berwyn:

Arrival-Apr. 25 (1903)-May 16 (1897); ave. 27 yrs. May 8.

Common-May 5 (1906)-May 22 (1897); ave. 14 yrs. May 13.

Departure-Sept. 15 (1913)-Sept. 25 (1894); ave. 7 yrs. Sept. 22.

167. Piranga rubra rubra Summer Tanager, "summer redbird." Straggler from the south. Barnard considered it very rare, and Michener, a rare summer resident. Dr. Warren saw a pair May 25, 1876 , and a female Oct. 10, 1889, all in West Chester, (Bds. Pa., 1890, 252).

168. Probne subis subis Purple Martin, "black martin," "martin," "swallow." Tolerable common summer resident. Colonies have been established in the past at Oxford, Avondale, Marshallton, Lenape, West Chester, Downingtown, Lionville, Byer's, Malvern, Berwyn, Paulding's bridge, Cupola and probably other points. Nidification commences soon after arrival and the set is complete by June $\mathrm{I}$.

Berwyn: 


\section{Arrival-Mar. 27 (1913)-Apr. 30 (1905);} ave. 13 yrs. Apr. 18.

Common-Apr. 18 (1889)-May 4 (1901); ave. 5 yrs. Apr. 28.

Departure-Aug. 18 (1900)-Sept. 24 (1896); ave. 7 yrs. Aug. 26.

169. Petrochelidon lunifrons lunifrons Cliff Swallow, "barn swallow," "eave swallow," "mud swallow." Not common transient, and rather rare and altogether local summer resident; formerly considered common. Pennock states that four or five stations about Kennett Square and one at Lenape are deserted (Cass., vi, 52); Sharples remembers a colony in 1870 on the S. E. wall of an old mill at Milltown, near West Chester; and Wilson reports that in 1880 , fifteen or sixteen pairs came to an old stone building on the mill property of David Y. Wilson, West Marlborough Twp., and built their nests for three or four years. A set of five eggs was taken near Berwyn, July 25, I896. Warren states that it arrives Apr. 28 to May 3.

170. Hirundo erythrogastra Barn Swallow. Common summer resident, less commonly than formerly however. Completed nests by May 13 .

Berwyn:

Arrival-Apr. 13 (1912)-May 3 (1907); ave. 25 yrs. Apr. 22.

Common-Apr. 15 (1912)-May 9 (1904); ave. 23 yrs. Apr. 28.

Departure-Aug. 19 ( 1898 )-Sept. II ( I902); ave. 7 yrs. Aug. 29.

I71. Iridoprocne bicolor Tree Swallow, "white- 
bellied swallow." Not common transient, and possibly a rare summer resident. Michener, Warren and Pennock considered it common, but Montgomery found it unfrequent, taking two specimens and observed two others on Apr. 25, 1891, by the Brandywine, and saw another three days later in West Goshen.

Dr. Warren informed me that he had observed several along the Brandywine, several times during the summer of 1889. Arrives Apr. 17 (1914)Apr. 25 (1891).

172. Riparia riparia Bank Swallow, "sand swallow." Not common transient. Apr. 25 to May 2, according to Barnard. Although this species has been known to breed in large colonies in the adjoining counties, and there are numerous local reports of its presence and nesting; I have been unable to confirm a single one with specimens, and neither Stone nor Montgomery ijund it nesting. However, if we are to credit the statements of Audubon, Michener and others, it was formerly a common summer resident along the Schuylkill, Brandywine, and other parts of the county; now apparently largely or altogether displaced by $S$. serripennis.

173. Stelgidopteryx serripennis Rough-winged Swallow, "bank swallow," "bridge swallow," "sand martin," "sand swallow." Common summer resident, especially along the Schuylkill and Brandywine. Nesting data: Chester valley, June 3, 1895 , five eggs. Migration data from all sources:

Arrival-Apr. 18 (1908)-May 13 (1909); ave. 7 yrs. Apr. 30. 
Common-Apr. 25 (1896)-May 13 (1904); ave. 4 yrs. May 7 .

174. Bombycilla garrula Bohemian Waxwing. Straggler from the north. The only authentic record appears to be that of H. B. Graves in 1860 (Warren, Bds. Pa., 244).

175. Bombycilla cedrorum Cedar Waxwing, "cedarbird," "cedar lark," "cherrybird," "Quakerbird." Common transient and resident; gregarious except when breeding. While Montgomery found it only once in winter about West Chester, and there are no mention of this species in the Christmas censo-horizons; nevertheless wandering flocks are not unusual thoroughout the winter. Nesting data: Berwyn, June 24, 1899, four eggs.

176. Lanius borealis Northern Shrike, "butcherbird." Not common winter visitant, Nov. 28 (1904)-Apr. 6 (I890).

177. Lanius ludovicanus migrans Migrant Shrike. Rare transient. Dr. Montgomery shot two males, West Goshen, Mar. 28, I896, first county records; and the skins are now in the Philadelphia Academy of Natural Sciences. C. J. Pennock reported it at Kennett Square, Dec. I2, 190I, and I. G. Roberts noted an individual at New London, Sept. 3 and Oct. 14, 1912, at Landenburg (Cass., v, 5I).

178. Vireosylva olivacea Red-eyed Vireo, "flycatcher," "greenlet," "hangbird." Abundant summer resident. Nidification begins May 20-28; average date for complete set, June 8. Extreme dates for fresh eggs, May 28-July 24. 
Berwyn:

Arrival-Apr. 21 (1893)-May 12 (1914); ave. 25 yrs. May 4.

Common-Apr. 29 (I 893)-May 17 (19021917); ave. 23 yrs. May 10.

Bulk departure-Aug. 3 I (1903)-Oct. 7 ( 1895 1897 ); ave. 13 yrs. Sept. 21.

Last seen-Sept. I 8 (1891-1901)-Oct. 26 (1900); ave. 20 yrs. Oct. 6.

179. Vireosylva philadelphica Philadelphia Vireo. Rare transient. Josiah Hoopes captured specimens at West Chester, Sept. 30 and Oct. 6, 1891 (Stone, Bds. E. Pa. and N. J., 126); and I shot an adult female (No. 685, coll. F. L. B.) Sept. 19, 1898, at Berwyn (Wils. Bull., 24, 7); the above appear to be the only records for the county.

180. Vireosylva gilva gilva Warbling Vireo. Tolerable common summer resident. W. L. Baily found newly made nest at Paoli, May 18, I891.

Berwyn:

Arrival-Apr. 30 (1906-1908)-May 12 (1914); ave. 14 yrs. May 7.

Common-May 8 (1916)-May 15 (1915); ave 3 yrs. May II.

Departure-Sept. 4 (1913)-Oct. 7 (1910); ave. 8 yrs. Sept. 19.

181. Lanivireo flavifrons Yellow-throated Vireo. Not common summer resident. W. S. Hall took a set of eggs, Willistown, July 2, 1884; and the writer found two nests: Valley Forge, June II, 1885 , and Berwyn, June $18,1899$.

Berwyn: 


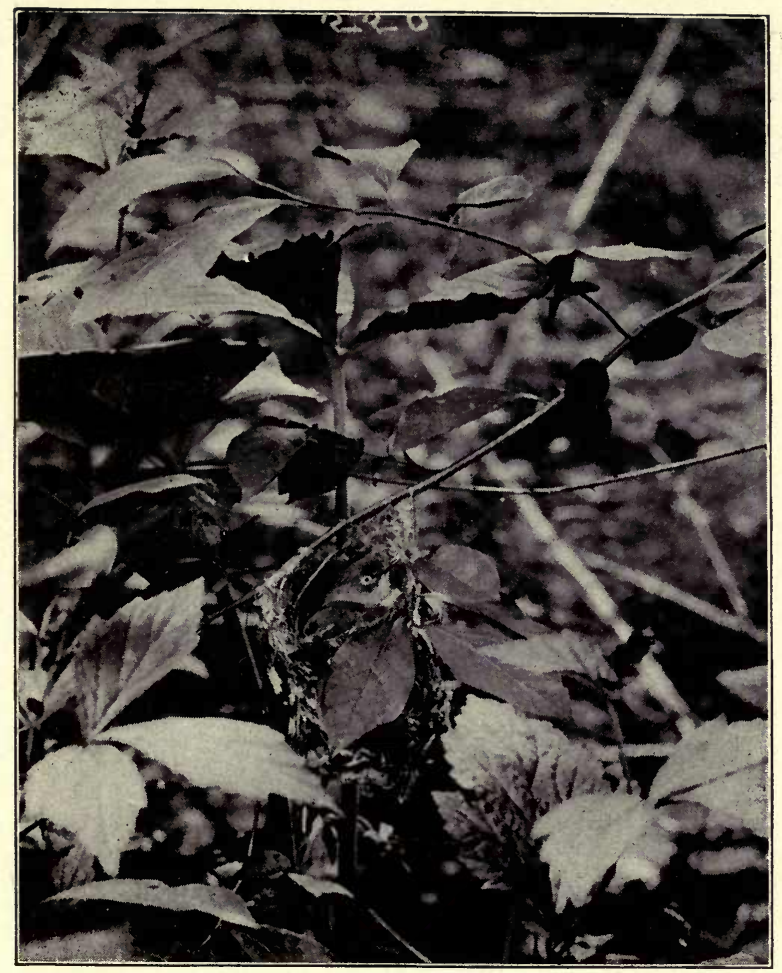

Photo by A. C. Redfield

W HITE-EYED VIREO ON NEST 


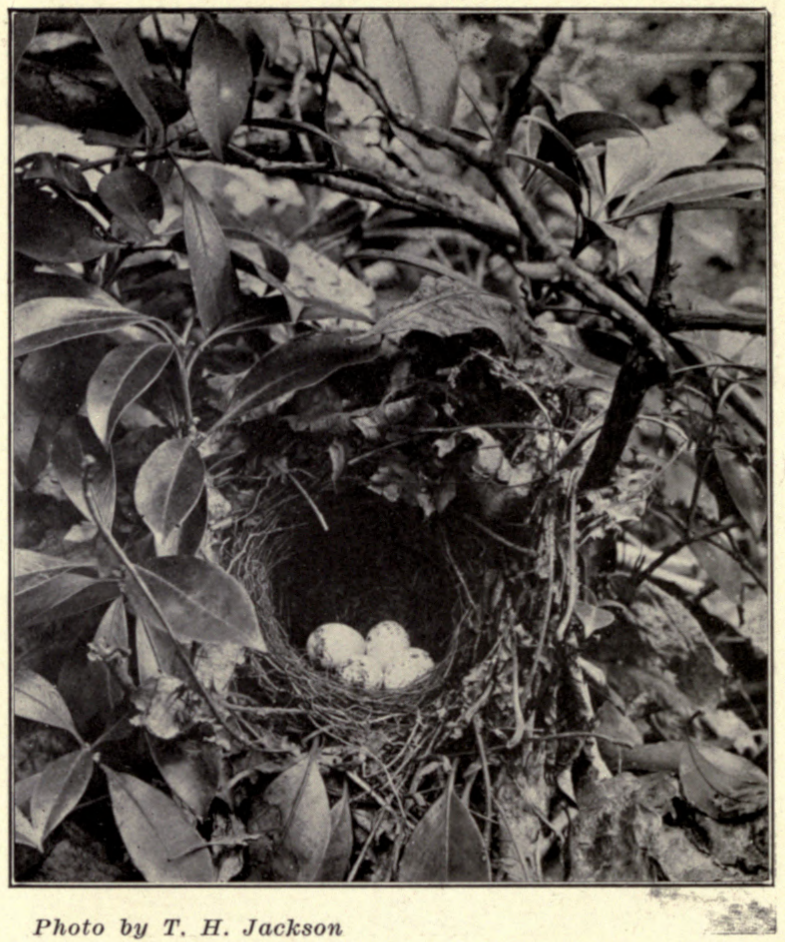

BLACK AND WHITE WARBLER NEST AND EGGS 
Arrival-May I (1904)-May I6 (1896); ave. 3 yrs. May 9.

182. Lanivireo solitarius solitarius Blue-headed Vireo. Tolerable common transient.

\section{Berwyn:}

Spring arrival-Apr. I7 (1916)-May 10 (1890); ave. 10 yrs. Apr. 27.

Fall arrival-Sept. 23 (1890)-Oct. 16 (1891) ; ave. 5 yrs. Oct. 6 .

183. Vireo griseus griseus White-eyed Vireo. Rather local, not common summer resident. Nesting data: Berwyn, June 13, 1888; four eggs.

Berwyn:

Arrival-May 5 (1892)-May 23 (1915); ave. 6 yrs. May 12.

Departure-Sept. 4 (1894)-Oct. I (1906); ave. 3 yrs. Sept. I 8 .

184. Mniotilta varia Black and White Warbler, "creeper," "little sapsucker." Rather abundant transient and tolerable common summer resident, especially on the Chester valley and Brandywine hills; though it is probable a great proportion do not breed. Rhoads records it feeding its young at Westtown in 1878 (B. N. O. C., iv, 234); Everett took the first set of eggs June 10, 1885, near Malvern (Orn. and Ool., xii, 25); Ladd found two sets now in the Norris collection, June 6, 1886 and May 29, 1887, Brandywine hills (Orn. and Ool., xii, 150); Sharples has a personally collected set from along the Brandywine, and Jackson found a nest near the latter locality June 26, 1903, another near Glenlock, and one with young June 6, 1890, 
near Whiteland station. I flushed five young from nest at Berwyn on June 3,1896 , and have observed fledgings almost every season (Chapman's Warblers of N. A., 42).

Berwyn:

Arrival-Apr. I7 (1900)-May 6 (1893-6); ave. 23 yrs. May I.

Bulk arrival-Apr. 29 (1914)-May 13 (1899$1900)$; ave. 16 yrs. May 5.

Bulk departure-Sept. 13 (1916)-Sept. 28 (1913) ; ave. 2 yrs. Sept. 20.

Last seen-Sept. 18 (1 888)-Oct. 7 (1895); ave. 6 yrs. Sept. 27.

185. Protonotaria citra Prothonotary Warbler. Straggler. Michener and Warren give it as an extremely rare summer resident. Dr. Warren has taken two specimens, one in midsummer, the other in May (Bds. Pa., 1890, 274).

186. Helmitheros vermivorus Worm-eating Warbler. Common summer resident, rather abundant in the second growth timber of the Octoraro, Brandywine and Chester Valley hills. The first authentic description of the nest and eggs was published by T. H. Jackson (Am. Nat., 3, 556) from the type set of five taken near West Chester, June 6 , 1869, and it has been found breeding the past thirty years with increasing frequency by Jackson, Ladd, Burns and others (Cf. Rhoads, B. N. O. C., vii, 55; Jackson, Orn. and Ool., x, I 76; xi, 156; Ladd, Ibid., xii, I 10, and 149; Norris, Ibid., xv, 117 ; Norris, Jr., Nid., i, 165; Burns, Bd. Lore, vii, 137; Chapman's Warblers N. A., 50). Nidifi- 
cation begins a few days after arrival and in the fifty or more records in the vicinity of Berwyn, the average date for a complete set is May 28 .

Berwyn:

Arrival-Apr. 30 ( I916)-May I4 (1896); ave. I 8 yrs. May 7.

Common-May 5 (1905)-May 19 (I901); ave. 13 yrs. May 12.

Departure-Aug. 29 ( I 896-1902)-Sept. 2 ( 1898 ) ; ave. 5 yrs. Sept. I.

187. Vermivora pinus Blue-winged Warbler. Common summer resident, apparently most abundant in the eastern part of the county, especially about Birmingham (Norris, Jr., Orn. and Ool., xiv, I38) and Berwyn (Burns, Wils. Bull., 35, 39). Also found breeding at Kennett Square, by Phillips (F. and S., vi, 215); West Chester, by Rhoads, (Coues, B. N. O. C., iii, 194) ; Willistown, by Hall (Orn. and Ool., 9, 137). Nidification commences soon after arrival; average date for complete set May 29 (Burns in Chapman's Warblers N. A., 67).

Berwyn:

Arrival-May 3 (1900-1905)-May I 5 (1896); ave. 2 I yrs. May 6.

Common-May 3 (1900)-May I7 (1917); ave. 12 yrs. May 8.

Departs-Aug. I3 (1890)-Sept. 6 (1897); ave. 4 yrs. Aug. 24 .

I88. Vermivora chrysoptera Golden-winged Warbler. Rare transient. I have no fall dates and include all spring records available: May 4 (I902) 
-May 25 (1907), ave. IO records May II.

189. Vermivora rubricapilla rubricapilla Nashville Warbler. Not common transient.

Spring arrival-Apr. 28 (1915)-May 15 (1904); ave. 9 records May 7.

Fall arrival-Sept. 13 (1912)-Oct. 8 (1891); ave. 3 yrs. Oct. 1 .

190. Vermivora celata celata Orange-crowned Warbler. Straggler. I took an adult male (No. 519, coll. F. L. B.) at Berwyn, Oct. 12, 1894 (Wils. Bull., 18,5 ), first county and third State record.

191. Vermivora peregrina Tennessee Warbler. Not common transient, formerly quite rare.

Berwyn:

Spring arrival-May 2 (1912)-May 13 (1917); ave. 3 yrs. May 9.

Spring departure-May 17 (1917)-May 21 (1916); ave. 2 yrs. May 19.

Fall arrival-Sept. 12 (1913)-Oct. 6 (1917); ave. 5 yrs. Sept. 27.

Fall departure-Oct. 6 (1915)-Oct. 8 (1914); ave. 3 yrs. Oct. 7 .

192. Compsothlypis americana usnea Northern Parula Warbler, Common, some times abundant, transient. According to Pennock, M. P. Barnard of Kennett Square, shot one in July, 1884; and Warren informs us that he has seen individuals as late as June 27 (Bds. Pa., 245).

Berwyn:

Spring arrival-Apr. 29 (I914)-May II (1904); ave. 8 yrs. May 7. 


\section{Annotated List}

Spring bulk-May 7 (1905)-May 20 (1915); ave. 8 yrs. May 13 .

Spring departure-May 1o (1903)-May 23 (1889); ave. 9 yrs. May 15.

Fall arrival-Sept. 5 (1895)-Oct. 27 (1893); ave. 6 yrs. Sept. 2 I.

Fall departure-Sept. 2 I (1898)-Oct. 3 I (1893); ave. 9 yrs. Oct. 6.

193. Dendroica tigrina Cape May Warbler, "grapebird," "little striped yellowbird." Common, sometimes abundant, transient; formerly quite rare (Burns, Auk. xxxii, 23I).

Berwyn:

Spring arrival-May 7 (1916)-May 15 (1914); ave. 15 yrs. May II.

Spring departure-May 15 (1910)-May 24 (1916); ave. 7 yrs. May 19.

Fall arrival-Sept. 3 (1916)-Sept. 16 (1917); ave. 5 yrs. Sept. 9 .

Fall bulk-Sept. 7 (1914)-Sept. 14 (1913); ave. 3 yrs. Sept. Io.

Fall departure-Sept. 25 (1909)-Oct. 20 (I9I4); ave. 6 yrs. Oct. 6.

194. Dendroica estiva astiva Yellow Warbler, "summer yellowbird." Not common transient and rather rare summer resident; formerly considered rather abundant in the southern and central parts of the county. J. P. Norris, Jr. found only one nest, and a few nests have been found in recent years by Thomas at Kennett Square, and Burn at Oxford.

Arrival-Apr. 22 (1917)-May 19 (1913); ave. 
Io yrs. May 6.

Common-May 7, 1905.

Last seen-Sept. 19, 1893; Sept. 20, I894.

195. Dendroica carulescens carulescens Blackthroated Blue Warbler. Common, sometimes abundant, transient.

Spring arrival-May I (1912)-May 21 ( I899); ave. I 8 yrs. May 8.

Common-May 7 (1909-1914-1916)-May 23 (1899); ave. 16 yrs. May 12.

Departure-May 8 (I909)-June 3 (1917); ave. 14 yrs. May 18 .

Fall arrival-Sept. 8 (1898)-Sept. 28 (1914); ave. 7 yrs. Sept. 16.

Common-Sept. 8 ( , 898 )-Sept. 28 (I913); ave. 2 yrs. Sept. 18.

Last seen-Sept. 16 (1905)-Nov. 4 (I917); ave. 16 yrs. Sept. 27.

196. Dendroica coronata Myrtle Warbler, "yellow-rump." Common transient, occasional winter visitant.

Berwyn:

Spring arrival-Apr. 7 ( I 893)-May 2 (I914); ave. 8 yrs. Apr. 24 .

Common-May 4 (1888)-May 12 (1906); ave. 6 yrs. May 6 .

Departure-Apr. 30 (1916)-May 17 (1917); ave. 10 yrs. May 9.

Fall arrival-Sept. 5 ( I 888)-Sept. 30 (I9I I ) ; ave. 4 yrs. Sept. 21.

Last seen-Oct. 8 ( I908)-Oct. 27 ( I 893 ) ; ave. 7 yrs. Oct. 18. 
197. Dendroica auduboni Audubon's Warbler. Straggler. Dr. Warren secured a fine adult female, Nov. 8, I 889, in an apple orchard, in company with Juncos and White-throated Sparrows (Bds. Pa., $1890,283)$. This is the first record for Pennsylvania and the second for the East. The specimen is now in his private collection.

198. Dendroica magnolia Magnolia Warbler. Common transient.

Berwyn:

Spring arrival-May 5 (1909)-May 17 (I9I7); ave. IO yrs. May II.

Common-May 13 (1904)-May 21 ( 1899); ave. 5 yrs. May 15 .

Departure-May I6 (1914)-May 30 (1917); ave. 8 yrs. May 2 I.

Fall arrival-Aug. 18 (1888-1896)-Sept. 7 (1893) ; ave. 5 yrs. Aug. 29.

Last seen-Sept. 19 (1893)-Oct. 7 (18951917) ; ave. II yrs. Sept. 27.

199. Dendroica cerula Cerulean Warbler. Rare transient. Listed by Barnard, Michener, Warren and Pennock. Dr. Montgomery shot a female in a swamp in West Goshen, May 10, 1890, and the skin is now in the collection of the Academy of the Natural Sciences of Philadelphia. Dr. Ehinger reported one seen and carefully identified at West Chester, May 9, 1914.

200. Dendroica pensylvanica Chestnut-sided Warbler. Common transient, and rare summer resident. Dr. Warren saw two, June 25, 1876, probably breeding. Pennock in behalf of S. B. 
Ladd, recorded the nesting of this bird on the South Valley hills not far from Frazer, May 27, 1900 (Abst. Proc. Del. Orn. Club, iv, 4), the set of four eggs are now in the Norris collection; Pennock observed a single bird in deciduous woods two miles beyond the serpentine barrens in the southern part of the county and not more than 250 feet above sea level, on June 16, 191 I (Auk, xxix, 247); and I found a nest with two young and one infertile egg at Berwyn, July 10, 1914 (Wils. Bull., 90, 288).

Berwyn:

Arrival-Apr. 30 (1916)-May I6 (1917); ave. Io yrs. May 8.

Common-May 8 (1909)-May 23 (1915-16); ave. 8 yrs. May 14 .

Departure-Sept. 28 (I 889)-Oct. 8 (I89I); ave. 5 yrs. Oct. 3 .

201. Dendroica castanea Bay-breasted Warbler. Not common transient.

Berwyn:

Spring arrival-May 8 (1909)-May 18 (I9I7); ave. 4 yrs. May 13. Spring departure-May 19 (1905)-May 30 (1917); ave. 5 yrs. May 23.

Fall departure-Sept. 16 (189I)-Oct. 5 (1895) ; ave. 3 yrs. Sept. 26.

202. Dendroica striata Black-poll Warbler. Common transient.

Berwyn:

Spring arrival-May 12 (1914)-May 16 (1896); ave. 4 yrs. May 16.

Spring departure-May 16 (1904)-June I 
(1917); ave. 4 yrs. May 27.

Fall arrival-Sept. 4 (1894)-Sept. 28 (1914); ave. 4 yrs. Sept. I 4 .

Fall departure-Sept. 27 (1913)-Oct. 18 (1914); ave. 3 yrs. Oct. 7.

203. Dendroica fusca Blackburnian Warbler. Not common transient.

Berwyn :

Spring arrival-May 8 (I909)-May 22 (1917); ave. 6 yrs. May 15.

Spring departure-May 14 (1914)-May 27 ( 1917 ) ; ave. 2 yrs. May 20.

Fall arrival-Aug. I8 (1896)-Sept. 7 ( 1891 ) ; ave. 4 yrs. Aug. 26.

Fall departure-Sept. 5 (1898)-Sept. 19 (1890-1891) ; ave. 3 yrs. Sept. I 4 .

204: Dendroica dominica dominica Yellowthroated Warbler. A straggler from the south. Dr. Warren has two specimens in his collection, both males, taken June 27, 1879, and July, I885 (Bds. Pa., 1890, 288).

205. Dendroica virens Black-throated Green Warbler. Common transient.

Berwyn:

Spring arrival-Apr. 30 (1908-1916)-May 9 (I9I2); ave. II yrs. May 4.

Spring bulk-May 3 (1914)-May 19 (1913); ave. II yrs. May 9.

Spring departure-May 7 (I9I6)-June I (I9I7); ave. II yrs. May 14.

Fall arrival-Aug. 28 (1896)-Sept. 24 (I916); ave. I I yrs. Sept. IO. 
Fall departure-Sept. 17 ( 1891 )-Oct. 7 (18951917); ave. 8 yrs. Sept. 28.

206. Dendroica townsendi Townsend's Warbler. Straggler from the far west. C. D. Wood, a Philadelphia taxidermist, killed an adult male near Coatesville, in an apple orchard; May 12, 1868. Sole Eastern record. This specimen was sold for $\$ 40$ to Dr. Turnbull, and after his death purchased by B. A. Hoopes, who subsequently disposed of it to John Krider (Warren, Bds. $\mathrm{Pa}$., 246). It later came into the possession of Prof. E. D. Cope, and is now in the Academy of Natural Sciences, Philadelphia (Stone, Osprey, iii, 98).

207. Dendroica vigorsi Pine Warbler. Not common transient. Barnard states that it arrives May 12 to 20; the only other spring dates we have are Berwyn, May 6, 1905, and Kennett Square, May 16, 1914, and Apr. 17, 1915 (Thomas MS.). Montgomery considered it common, and offered the following occurrences: Oct. 1-8, 1887; Sept. 19, 1889; Sept. I 7 to Oct. I 8, I 890.

208. Dendroica palmarum hypochrysea Yellow Palm Warbler. Not common transient. Dr. Montgomery shot five specimens and saw a few others in April, 1891. Dr. Warren gives it as an abundant migrant, Apr. 20 to 30. I secured a pair in Devon swamp, Oct. 7, 1895 (Nos. 568 and 569, coll. F. L. B.). Migration records from all sources:

Spring arrival-Apr. 9 (1915)-Apr. 25 (1897$1915)$; ave. 8 yrs. Apr. 19.

Fall arrival-Oct. 7 (1895)-Oct. 24 (1908); ave. 2 yrs. Oct. 15. 
209. Dendroica discolor Prairie Warbler. Rare transient, and common summer resident in the southern part of the county. Dr. Montgomery has seen it only on two dates, May 10, 1890, when three were seen and a female secured, and on May 2, 1897. Dr. Warren observed it on different occasions during the summer months on the Barren ridge (Bds. Pa., 1890, 293) ; Pennock and Carter found it quite abundant and probably breeding in the serpentine barrens of the southern border, June 16, I91 I (Auk, xxix, 245); and Burn saw a male near Chrome, in the same locality, on July 3, I916.

Spring arrival-May 2 (1897)-May 25 (1907); ave. 4 yrs. May II.

2 10. Seiurus aurocapillus Ovenbird, "ground thrush." Abundant summer resident. Nidification begins about May 18; average date for complete set, May 29.

Berwyn:

Arrival-Apr. I3 (1890)-May 12 (1888-9); ave. 28 yrs. Apr. 30 .

Common-Apr. 28 (19ro-II)-May 13 (1902); ave. 26 yrs. May 5 .

Bulk departure-Aug. 29 ( $1896-1902)-O c t . ~ 3$ (I908) ; ave. 8 yrs. Sept. 9.

Last seen-Sept. 12 (1913)-Oct. 7 (1897); ave. 9 yrs. Sept. 25 .

2II. Seiurus noveboracensis noveboracensis Water-Thrush. Not common. Montgomery took a specimen on May 10, 1890, West Goshen Twp., and I secured another at Berwyn, Sept. 22, 1906 (No. 892 , coll. F. L. B.). 


\section{The Ornithology of Chester County}

Spring arrival-Apr. It (1912)-May 10 (1890); ave. 5 yrs. May 7.

Spring departure-May 14 (1912)-May 30 (1907) ; ave. 3 yrs. May 25.

212. Seiurus motncilla Louisiana Water-Thrush. Rare summer resident. Warren has taken a few specimens in summer (Bds. Pa., 1890, 295) ; Jackson and Ladd searched a ravine near Whitford, for several seasons without locating its nest, though a pair of this elusive species was present. A pair inhabited an extensive and well watered tract of woods near Daylesford, for several years, and I found one young bird apparently just out of the nest, June 3, 1899; a pair was present on May 6, 1906 and May 8, 1909, but the nest was not found (Wils. Bull., 28, 75; 59, 73). Pennock took a specimen at Kennett Square, Apr. 19, 1909.

213. Oporornis formosus Kentucky Warbler, "yellowbird." Common summer resident, often rather abundant in the vicinity of Birmingham meeting house, West Chester and Berwyn; formerly quite rare (Cf. Rhoads, B. N. O. C., iv, 234; Hall, Jackson, Norris, Jr., Norris, Sr., Orn. and Ool., ix, 137; xii, 43; xiv, 104; xv, 145; xvii, I ; Norris, Jr., Nid. i, 165; and Burns in Chapman's Warblers N. A., 237). Nidification commences about May 25; in thirty instances the average date for a complete set of eggs is June 3 .

Berwyn:

Arrival-May 3 (1896-1900)-May 16 (1917) ; ave. 17 yrs. May 8.

Common-May

9 (1904-1910)-May

22 


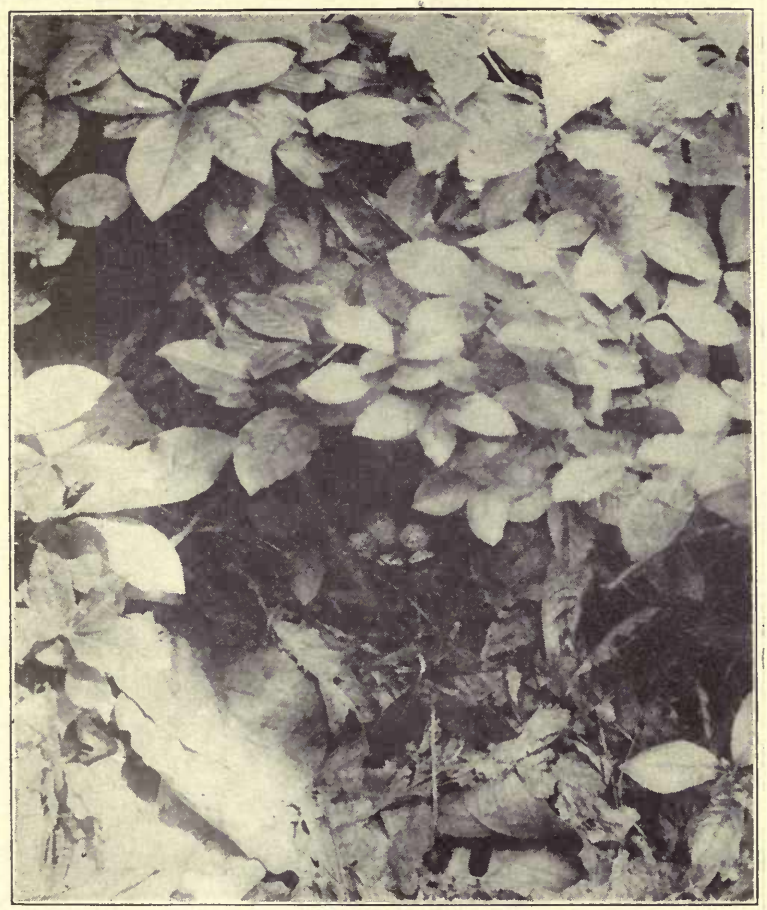

Photo by A. C. Redfield

WORM-EATING WARBLER NEST AND EGGS 


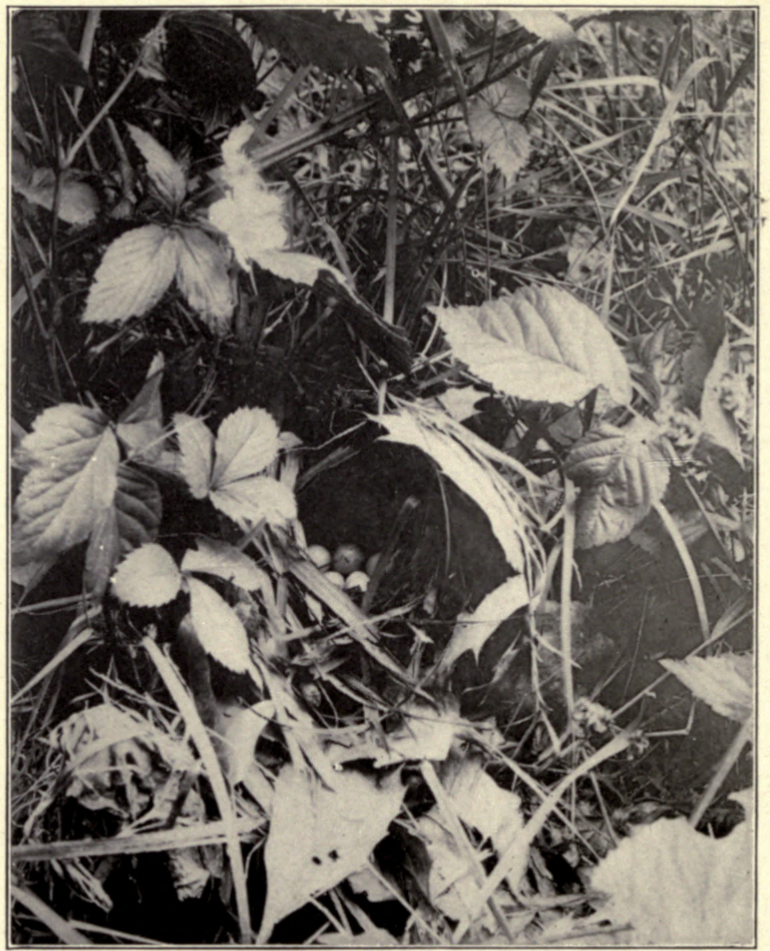

Photo by A. C. Redfield BLUE-WINGED WARBLER NEST AND EGGS 
(1897); ave. 15 yrs. May 14.

Departure-Aug. 11 (1902)-Sept. 14 (1896); ave. 9 yrs. Aug. 23.

214. Oporornis agilis Connecticut Warbler. Rare transient. Dr. Montgomery collected specimens Sept. 20 and 28, 1889, and saw another Sept. 25, all in West Goshen; and I took single birds on Sept. I1, 1893 and Oct. 7, 1897 (Nos. 423 and 636, coll. F. L. B.). There are no spring records.

Fall arrival-Sept. 19 (1893)-Oct. 7 (1897); ave. 5 records Sept. 26.

215. Oporornis philadelphia. Mourning Warbler. Rare transient. Michener gave it as a summer resident, extremely rare. Four specimens have been taken by Josiah Hoopes and Witmer Stone (Bds. E. Pa. and N. J., I39) ; and according to Warren, Harry Garrett of Willistown has also taken specimens. Pennock states that on June 19, 1886, a female, which had been found a few days before, was brought to him, and a male was seen in the same vicinity about June 12. The inference is that the pair would have nested in the neighborhood (Ool., iii, 46).

Spring arrivals-May 15 (1892)-May 27 (1909); ave. 6 records. May 20. There are no fall records.

216. Geothlypis triches trichas Maryland Yellowthroat, "muff wren," "wild canary," "yellowbird," "yellow wren." Common summer resident. Nidification usually begins by May 15; average date for complete set, May 26.

Berwyn: 
102 The Ornithology of Chester County

Arrival-Apr. 23 (1910)-May 9 (1894); ave. 20 yrs. Apr. 30.

Common-Apr. 29 (1914)-May 21 (1899); ave. 13 yrs. May 12.

Bulk depart-Sept. 4 (1894)-Sept. 25 (1895); ave. 6 yrs. Sept. 16.

Last seen-Sept. 19 ( 1 893)-Oct. II (1897); ave. 14 yrs. Oct. 2.

217. Icteria virens virens Yellow-breasted Chat, "chat," "oriole." Tolerable common summer resident; inclined to nest in small colonies. Nidification commences by May 20; average date for complete set, May 30.

Berwyn:

Arrival-May 2 (190;)-May 19 (1917); ave. 12 yrs. May 9.

Common-May 12 (1905)-May 26 (1914); ave. 9 yrs. May 16.

Bulk depart-Aug. 8 (1900)-Sept. 4 (1894); ave. 2 yrs. Aug. 21.

Last seen-Aug. 21 (1896)-Sept. 4 (1894); ave. 3 yrs. Aug. 27.

218. Wilsonia citrina Hooded Warbler. Not common transient. A female taken at Berwyn, May I I, 1898 (No. 644, coll. F. L. B.).

The only autumnal record I have is that of an adult male found dead in a yard in West Chester Sept. 28, 1915, by R. P. Sharples, and now in the possession of Miss Sara DeHaven.

Spring arrival-May I (1909)-May 4 (1912); ave. 4 records May 3 .

Spring departure-May II (I 899-1909-1910)- 
May I4 (1914); ave. 6 records May 12.

219. Wilsonia pusilla pusilla Wilson's Warbler. Tolerably common trancient. I took a female with black cap on May 18, I 896, at Berwyn (No. 596, coll. F. L. B.). 'There are no fall records available.

Spring arrival-May 8 (1909)-May 20 (I9I7); ave. II records May I3.

Spring departure-May 16 (1902-1905)May 30 (1907); ave. 12 yrs. May 19.

220. Wilsonia canadensis Canada Warbler. Tolerably common transient.

Berwyn:

Spring arrival-May 9 (I909)-May 22 (1917), ave. 9 yrs. May 16.

Spring departure-May I6 ( (896)-May 30 (1907-1917); ave. 6 yrs. May 22.

Fall arrival-Aug. I 3 ( I 89I)-Aug. 26 (1 898); ave. 2 yrs. Aug. 19 .

Fall Departure-Aug. 31 ( $189 \mathrm{I}$ )-Sept. 8 (1898) ; ave. 2 yrs. Sept. 4.

221. Setophaga ruticilla Redstart. Common, sometimes abundant, transient, and rare summer resident. Dr. Warren thinks it probably breeds. I found it present and in song at Berwyn on June 9, 16 and 27, 1907 (Wils. Bull., 61, 163), also June 8,1915 , and while it probably bred, no nests or young were found.

Berwyn:

Spring arrival-Apr. 27 (1911-1913)-May 8 (1895); ave. 13 yrs. May 4.

Spring departure-May i ( 1895 )-June I 


\section{The Ornithology of Chester County}

(1910-1917); ave. 18 yrs. May 22.

Fall arrival-Aug. 8 (1914)-Sept. II (1893); ave. 13 yrs. Aug. 27.

Fall departure-Sept. 6 (1897)-Oct. 3 (1894); ave. 12 yrs. Sept. 21.

222. Anthus rubescens Pipit, "titlark." Irregular winter visitant. Montgomery observed a flock of 100 individuals Apr. 14, 1888, and Pennock the same number on Apr. 11, 1912.

Arrival-Oct. 8 (1911) -Dec. 25 (1907-1911); ave. 4 yrs. Nov. 18 .

Departure-Mar. 20 (1908)-May 10 (1915); ave. 10 yrs. Apr. 12.

223. Mimus polyglottos polyglottos Mockingbird. Rare resident. Dr. Michener gives it as a summer resident; Barnard took a nest and parent birds one mile east of Kennett Square, and another specimen was shot near the same place in 1872 , according to Pennock. From B. M. Everhart, Dr. Warren learned that about 1859 , several individuals built nests and reared young for two or three consecutive years in the thorn hedges on the property of the Misses Bennett, West Chester. Several stragglers have occurred: Eagle (Strafford) about 1880 , collected by D. N. McCadden (Stone, Bds. E. Pa. and N. J., 142) ; Berwyn, one observed about my yard from Nov. II to Dec. 2, I 909 (Redfield, Cass., xiv, 44) ; Kennett Square, Dec. 15, 1910, to Jan. 4, I9I I, by C. J. Pennock; Westtown, Nov. and Dec., 1914, by George Forsythe, and wintering at the same place 1914-15, by Morris; and West Chester, Dec. 25, 1916, by Dr. Ehinger. That the species is still 
with us as a breeder is proven by Isaac G. Roberts. On June 25, 1915, he noticed a single individual near Jennersville, just west of West Grove; and on the 26th discovered the adults, nest and three young which appeared to be but a few days old. On July 4 it was deserted. The nest was five feet up in a small cedar, at the head of a lane close to the public road, and not far from a tall osage hedge. A single bird was observed near West Grove, Aug. I 8 and 21, 1916, and Sept. 18, 1917 (Roberts MS.).

224. Dumetella carolinensis Catbird, "cattie," "catbird," "chickenbird." Abundant summer resident. Nidification begins about May 20; average date for complete set, May 29.

Berwyn:

Arrival-Apr. 22 (1905)-May 9 (1885-1886); ave. 32 yrs. May 2.

Common-Apr. 27 (1902-1903-1913)-May I4 (189I-I90I) ; ave. 29 yrs. May 6.

Bulk departure-Sept. 13 (1905)-Oct. 4 (1904); ave. 15 yrs. Sept. 25.

Last seen-Sept. 16 (1896)-Dec. I (1898); ave. 25 yrs. Oct. 6.

225. Toxostoma rufrum Brown Thrasher, "brown thrush," "thrasher," "thrush." Tolerably common summer resident; occasional resident. $\dot{A}$ single individual found wintering at Berwyn, Feb. I0, 19 and 21; Mar. 5 and 10, 1915; Mar. 25, 1916. Nidification begins about May 5; average date for complete set, May $2 \mathrm{I}$.

Berwyn:

Arrival-Apr. 5 (1910)-May 5 (1889); ave. 
106 The Ornithology of Chester County

24 yrs. Apr. 22.

Common-Apr. 24 (I916)-May I8 (1889); ave. 13 yrs. May 4.

Bulk departure-Sept. 3 (I909)-Oct. I (1915) ; ave. 4 yrs. Sept. 16.

Last seen-Sept. 12 ( I903)-Oct. 26 ( I889); ave. 24 yrs. Sept. 29.

226. Thryothorus ludovicianus ludovicianus Carolina Wren, "ground pewee," "wren." Resident; most erratic, sometimes almost abundant in the fall; frequently scarce or absent. I have records of its occurrence in all months in the year except January and especially common in August and September, at Berwyn, after several years of scarcity or absence; during the seasons of $1902-06$; after which it has again become casual. It is a rather scarce breeder: Jackson found it nesting in an outhouse at Edge's mill, Beaver creek; in a shed at Edw. Swayne's home, West Bradford, and near Laural station on the Brandywine. Sharples found a pair nesting in a springhouse at Green Hill, 1912; Burn has found but a single nest at Oxford, and Thomas a nest and eggs in a chickenhouse at Kennett Square, summer of 1912.

227. Thryomanes bewicki Bewick's Wren. Straggler. Barnard classes it as very rare and Michener as a resident. The only recent record is by Pennock, Kennett Square, Apr. I9, 1903 (Cass., vii, 70).

228. Troglodytes aedon aedon House Wren, "jackywren," "jennywren," "little wren." Common summer resident. Nesting data: Berwyn, June I, 1892 ; six eggs. It is interesting to note in com- 
parison, that in eight instances where the first arrival was observed at the home box (hence undoubted local birds) the average date was Apr. 26; while the first arrivals in the neighborhood for the same years averaged six days earlier.

Berwyn:

Arrival-Apr. I6 (1908)-May 6 (1904); ave. 24 yrs. Apr. 24.

Common-Apr. 18 (1896)-May ro (1904); ave. 2 I yrs. Apr. 30.

Departure-Sept. I5 (1899)-Nov. I4 (1903); ave. 20 yrs. Oct. 14.

229. Nannus hiemalis hiemalis Winter Wren. Not common winter visitant; represented by record of from one to four individuals on most winter lists. Arrival-Oct. 5 (1894)-Nov. I5 (1913); ave. 7 yrs. Oct. 20.

Departure-Apr. I I (I890)-May 2 (I915); ave. 5 yrs. Apr. 25.

230. Cistothorus stellaris Short-billed Marsh Wren. Rare summer resident. Barnard considered it very rare, while Michener gave it as a frequent summer resident. Warren has observed it as a summer resident but gives no dates, and Burn reports it at Oxford.

231. Telmatodytes palustris palustris Long-billed Marsh Wren. Rare summer resident; frequent in Michener's time. Jackson and Ladd took a set of six eggs from a marsh, at Lenape, June 12, I886 (Orn. and Ool., xii, 24).

232. Certhia familiaris familiaris Brown Creeper. Tolerable common winter visitant. 


\section{The Ornithology of Chester County}

Arrival-Sept. 25 (1890)-Oct. 23 (1896); ave. 9 records Oct. 12.

Departure-Mar. 26 (1910)-May I (1914); ave. 10 records Apr. 15.

233. Sitta carolinensis carolinensis White-breasted Nuthatch, "sapsucker," "woodpecker." Tolerable common resident, less frequent in the nesting season. Dr. W. E. Rotzell and the writer took a set of nine eggs near Berwyn, Apr. 27, 1889.

234. Sitta canadensis Red-breasted Nuthatch, "sapsucker." Not common transient.

Fall arrival-Sept. I (1903)-Sept. 25 (1915); ave. 5 records Sept. 14 .

Fall departure-Oct. 7 (1916)-Nov. 15 (I9I6); ave. 9 records Oct. 20.

Spring departure-Apr. 27 (1889)-May 10 (1916); ave. 5 records May 4.

235. Baolophus bicolor Tufted Titmouse, "bluebird," "little jay," "tit." Rare resident, noticed more often during the spring migrations, especially February, March and April. Wilson reports it a winter or spring visitant in Highland Twp.; Hunt has dates for every month in the year in Honeybrook and Nantmeal Twps. Jackson informs me that it undoubtedly breeds along the Brandywine below Downingtown, but he has never actually located its nest. Pennock, apparently, has found it breeding but gives no dates; Thomas found a nest at Kennett Square in the summer of 1908 , date not recorded.

236. Penthestes atricapillus atricapillus Chickadee, "chickadee-dee," "sapsucker," "tit," "titmouse," "tomtit." Tolerable common winter visitant. All 
our listmakers except Montgomery give it as resident and breeding; Hunt of Cupola, Wilson of Gum Tree and Burn of Oxford, however, return it as a winter visitant; which is in accord with the observations of Stone, Montgomery and myself. It is very erratic in arrival at Berwyn; Oct. 6 (1914) to Jan. 13, (1903); and departing Mar. 5 (1903) to May I (1904). From Oct. 12, 1913, to Apr. 7, 1914, it was really common at Berwyn, and is said to have been present in unprecedented numbers at West Chester. I took a pair in the Paoli barrens, Dec. 10, 1892 (Nos. 362 and 363 , coll. F. L. B.).

237. Penthestes carolirensis carolinensis Carolina Chickadee, "Carolina titmouse," "sapsucker," "titmouse," "tit," "tomtit." Not common summer resident. Dr. W. L. Hartman, formerly of West Chester, now of Pittston; informs me that he took six sets of four eggs each, in I864 and I865, and to satisfy John Krider of Philadelphia that the nest was that of the Carolina Chickadee, he shot the male parent for him. I have found new nests near Berwyn on May 6, I888; May 16, I889, and later found pairs present, but no eggs have been taken.

Berwyn:

Arrival-Mar. I (1902)-Apr. 27 (1914); ave. 7 yrs. Mar. 21.

Departure-Oct. 17 (I901)-Dec. Io (I902); ave. 4 yrs. Nov. 8 .

238. Regulus satrapa Golden-crowned Kinglet. Abundant transient, and frequent winter resident in sheltered situations.

Berwyn: 


\section{I10 The Ornithology of Chester County}

Arrival-Sept. 24 ( 1898$)$-Nov. 30 (1890); ave. 24 yrs. Oct. 9 .

Departure-Mar. 14 (1899)-May 2 (19041914); ave. 2 I yrs. Apr. 23.

239. Regulus calundula calundula Ruby-crowned Kinglet. Abundant transient.

Berwyn:

Spring arrival-Apr. 15 (1917)-Apr. 27 (1910); ave. 12 yrs. Apr. 21.

Spring departure-May 2 (1904)-May 18 (1905); ave. 6 yrs. May 9.

Fall arrival-Sept. 21 (1898-1901)-Oct. 15 (1896); ave. 14 yrs. Oct. 6.

Fall departure-Oct. 12 (1898)-Nov. 27 (1915); ave. 14 yrs. Oct. 26.

240. Polioptila carula cerula Blue-gray Gnatcatcher. Straggler; Formerly a summer resident. Michener considered it frequent in summer and Barnard notes its arrival Apr. 15 to 25. The only recent records are of one observed at Kennett Square, Apr. 19, 1914, by Thomas (Cass., xviii, 6I), and another at Berwyn, May 19-21, 1914, by the writer.

24I. Hylocichla mustelina Wood Thrush, "Peter and Paul," "song thrush," "wood robin." Common, in some localities, abundant; summer resident. Nidification begins about May 16; average date for complete set, May 27.

Berwyn :

Arrival-Apr. II ( I890)-May 9 (1885); ave. 33 yrs. May 1 .

Common-Apr. 30 (1890)-May 18 (1898); 
ave. 28 yrs. May 8 .

Departure-Sept. 21 ( 1898 )-Nov. 6 ( (1886); ave. II yrs. Oct. 7 .

242. Hylocichla fuscescens fuscescens Wilson's Thrush, "Veery." Not common transient. Dr. Montgomery has taken it only in spring, and I have but one fall record, Sept. 19, 1893 (No. 421, coll. F. L. B.).

Arrival-Apr. 30 (1905)-May 14 (1916) ; ave. 6 yrs. May 6.

Departure-May 16 (1916)-May 26 (1917); ave. 4 yrs. May 21.

243. Hylocichla alicia bicknelli Bicknell's Thrush. Rare transient. One was taken at West Chester by Josiah Hoopes in 1893 (Stone, Bds. E. Pa. and N. J., 150), and another at Berwyn in my orchard while feeding on pokeberries, Oct. 6, 1915 (No. 1063 , coll. F. L. B.); the first and second county records.

244. Hylocichla ustulata ustulata Olive-backed Thrush. Tolerable common transient.

Berwyn:

Spring arrival-Apr. 22 (1896)-May 4 (1904); ave. 4 yrs. Apr. 28.

Spring departure-May 13 (1904-1906-1909)May 30 (1907); ave. 7 yrs. May 18.

Fall arrival-Sept. 20 (1895)-Sept. 26 (18971903) ; ave. 3 yrs. Sept. 24.

Fall departure-Oct. 3 ( 1891 )-Oct. 26 (1900); ave. 4 yrs. Oct. 12.

245. Hylocichla guttata guttata Hermit Thrush, "wood robin." Common, sometimes rather abund- 


\section{The Ornithology of Chester County}

ant, transient.

Spring arrival-Apr. 9 (1905)-Apr. 28 (19II) ; ave. 8 yrs. Apr. 19.

Spring departuri-Apr. 27 (1900)-May 12 (1907); ave. 6 yrs. May 4.

Fall arrival-Sept. 12 (1913)-Oct. 8 (1915); ave. 8 yrs. Sept. 26.

Fall departure-Oct. 9 (1890)-Nov. 14 (1903); ave. 19 yrs. Oct. 26.

246. Planesticus migratorius migratorius Robin, "redbreast," "robin," "robin-redbreast." Abundant summer resident; occasional resident. Nidification usually commences by April 27, and nest is completed by April 30.

Berwyn:

Arrival-Feb. 7 (1912)-Mar. 17 (1888); ave. 32 yrs. Mar. 2.

Common-Feb. 2 I (1906)-Apr. 5 (I 895); ave. 33 yrs. Mar. 14.

Bulk departure-Oct. 7 (1903)-Nov. 5 (1907); ave. 27 yrs. Oct. 24.

Last seen-Oct. 27 (I915)-Dec. 3 (I89I); ave. 33 yrs. Nov. II.

247. Sialia Sialis sialis Bluebird. Tolerable common summer resident; occasional resident. Nidification begins about April 15; complete set April 30.

Berwyn:

Arrival-Jan. 17 (I901)-Mar. 25 (1912); ave. 33 yrs. Feb. 19.

Common-Jan. 30 (1892)-Apr. 28 (I9II); ave. 29 yrs. Mar. 2.

Bulk departure-Oct. 7 (1915)-Nov. 15 
(r 894 ) ; ave. 25 yrs. Oct. 30.

Last seen-Oct. 20 (1904)-Dec. 27 (1900); ave. 32 yrs. Nov. 20.

\section{SUMMARY}

Resident (not necessarily in the individual sense) ............... 26 species Summer resident (including 17 species that are occasional resident)... 72 " Winter visitant ............... 26 " Transient visitant (including 9 species that are occasional winter visitant) 75 " Straggler .................42 " Extirpated ............... 6 "

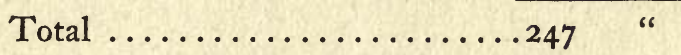

\section{HyPothetical LisT}

1. Mergus serrator Red-breasted Merganser (included in Michener's later list without comment).

2. Nettion carolinensis Green-winged Teal (included in Michener's later list without comment).

3. Marila marila Scaup Duck (included in Michener's later list without comment).

4. Marila collaris Ring-necked Duck (included in Michener's later list without comment).

5. Harelda hyemalis Old-squaw (included in Michener's later list without comment).

6. Olor columbianus Whistling Swan (included in Michener's later list without comment). 
114 The Ornithology of Chester County

7. Coturnicaps noveboracensis Yellow Rail (included in Michener's later list without comment).

8. Lobipes lobatus Northern Phalarope (included in Michener's later list without comment).

9. Macrorhamphus griscus griscus Dowitcher (included in Michener's later list without comment).

Io. Pisobia maculata Pectoral Sandpiper (included in Michener's later list without comment).

I1. Pelidna alpina alpina Dunlin (included in Michener's later list without comment).

12. Numenius americanus Long-billed Curlew (included in Michener's later list without comment)

13. Egialitis meloda Piping Plover (reported by Harry Wilson to have occurred in Highland Twp. about 1900).

I4. Surnia ulula caparoch Hawk Owl (reported as occurring at Oxford, by Casper G. Burn).

15. Carduelis carduelis European Goldfinch (reported seen at Westtown, Aug. 19, 1912, by Sarah C. DeHaven).

16. Hylocichla alicia alicia Gray-cheeked Thrush (appears on several manuscript lists, and Michener in his first list gives it as very rare, doubtful). 


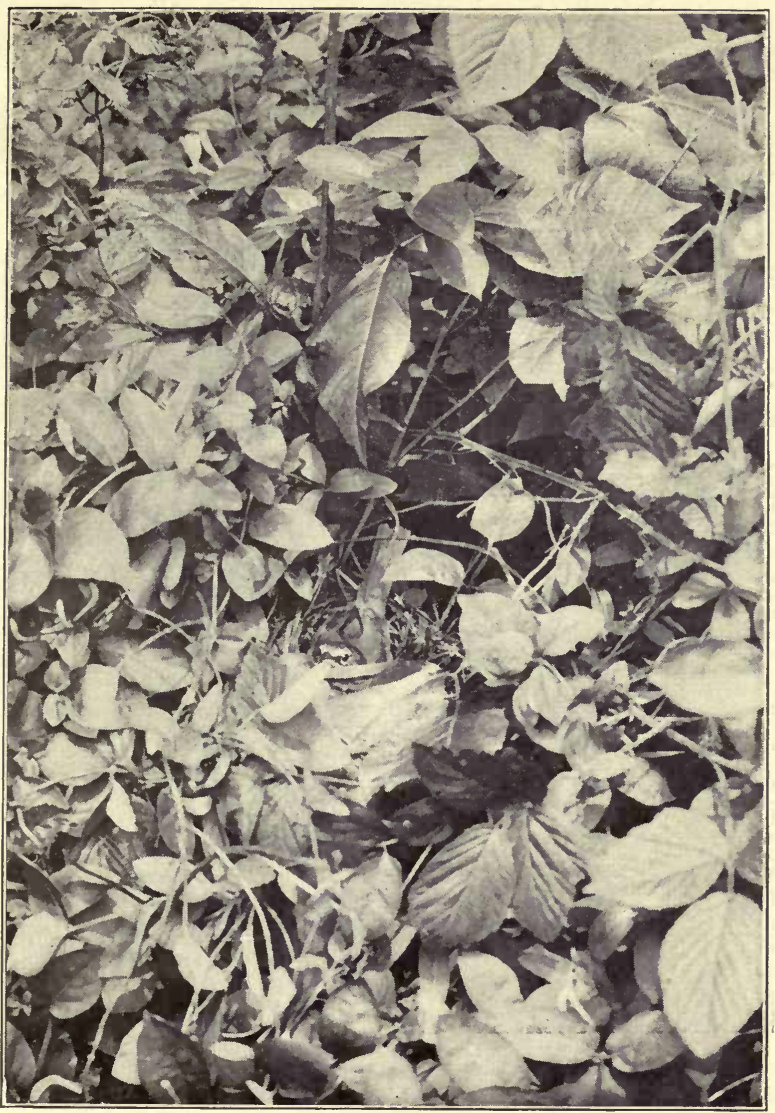

Photo by A. C. Redfield YELLOW-BREASTED CHAT ON NEST 


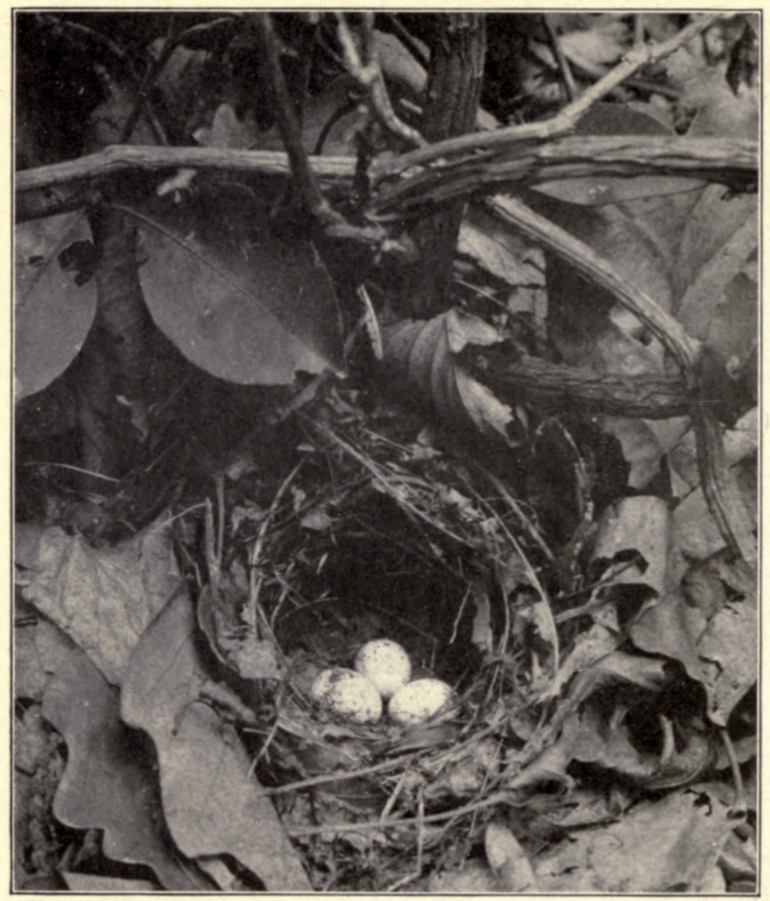

Photo by T. H. Jackson

KENTUCKY WARBLER NEST AND EGGS 


\section{PART III}

BIBLIOGRAPHY OF FAUNAL LISTS

BARNARD, VINCENT. A Catalogue of the Birds of Chester County, Pennsylvania, with Their Times of Arrival in Spring, from Observations Annually for Ten Successive Years. (Fifteenth) Ann. Report Smithsonian Inst. (for 1860), pp. 434-438, (I9I species).

MICHENER, E., M. D., Avondale; Penn'a. Agricultural Ornithology. Insectivorous Birds of Chester County, Pennsylvania. Report of Com'r of Agriculture for $1863, \mathrm{pp} .287-307$, ( 186 species, land birds only).

P(HILLIPS), C. F. Birds of Southern Pennsylvania. Forest and Stream, vi, 5, Mar. 9, 1876, p. 67, (2I species, mostly in vicinity of Kennett Square).

WARREN, B. HARRY. The Birds of Chester County, Pa. Forest and Stream, xiii, 1879, pp. 1024-1025; xiv, 1880, pp. 6 and 25, (218 species).

M(ICHENER), E(ZRA). Birds of Chester County, Penna. History of Chester County, Pennsylvania. By $T$. Smith Futhey and Gilbert Cope, Philadelphia, I88I, pp. 44I-445, (232 species).

WARREN, B. HARRY, West Chester, Pa. Diurnal Rapacious Birds (With special reference to Chester County, Pa.) Penna. Agri. Report for 1883, pp. 96-109, (I0 species).

WARREN, B. H. Our Home Feathered Tribe. A Complete List of the Birds that Sing, Warble, 


\section{The Ornithology of Chester County}

Carol, Twitter, Nest and Help Make Up Charming Chester Countv. West Chester Local News, Sept. 3 and 10, 1885. (80 species, resident and summer resident).

PENNOCK, C. J., Prepared by; Kennett Square, $\mathrm{Pa}$. The Birds of Chester County. 29th and 3oth Quarterly Reports of the Pennsylvania Board of Agriculture, October, November and December, 1885, January, February and March, 1886. Harrisburg, Edwin K. Meyers, State Printer. 1886. pp. 78-91. (236 species).

PENNOCK, C. J., Prepared by ; Birds of Chester County, Penn. The Oologist, vol. 4, no. I, Jan. and February, 1887, pp. 1-10. (236 sp.).

RESSEL, CYRUS B. (Ercildoun, Pa.) Birds of Chester County, Penn. Ornithologist and Oologist, xiv, July-Sept., 1889, pp. 97-101, 113-116, $120-130$, and 158 and 175 for criticism. (199 species).

JACKSON, THOMAS H. West Chester, Pa. Notes on the Owls of Chester County, Pa. The Kansas City Scientist, v. 1, Jan., 1891, pp. I-3. (8 species).

BURNS, FRANK L. Some remarks on the "Birds of Chester County, Pa." Wilson Bulletin, No. 12, Jan. 30, 1897, pp. 1-4, and No. 22, Sept. $30,1898, p p .68-69$.

MONTGOMERY, THOS. H., M. D. A List of the Birds of the Vicinity of West Chester, Chester County, Pennsylvania. The American Naturalist, $x \times x i, 1897, p p .622-628,811-814$ and $908-$ 911. (145 species). 
BURNS, FRANK L. A Sectional Bird Census. Taken at Berwyn, Chester County, Pennsylvania, During the Seasons of 1899,1900 and 1901. The Wilson Bulletin No. 37, Dec., 1901, pp. 84-103. (62+20 species).

BURNS, FRANK L. Second Sectional Bird Census, 1914, Taken at Berwyn, Chester County, Pennsylvania. Bird-Lore, xvii, Mar.-Apr., 1915, pp. I09-III. (60+20 species).

BURN, CASPAR G. MS. "Local Birds of Southern Chester County, Pa." (Oxford and vicinity; received Mar. 1, 1916; 102 species).

THOMAS, C. AUBREY. MS. Bird List and Migration Record for 1907-1915, Taken in the Vicinity of Kennett Square. (This includes some of the Pennock records for the same period, Received Mar. 28, 1916; 153 species).

WILSON, H. MS. "Birds of Western Chester County, Pa." Dated Mar. 2 and Apr. 6, 1916. (Mostly the rarer birds of Highland township; 35 species).

HUNT, CHRESWELL J. MS. "Birds of Honeybrook and West Nantmeal Townships, Chester County, Pa." Feb. 9, 1917. (Principally a list of the breeding birds of the upper branches of the Brandywine creek and the Welsh mountain region in the vicinity of Cupola and Honeybrook, observed during the vacations of 1901 to 1909 inclusive; 97 species). 



\section{NOTES}

II am indebted to Edwin B. Bartram for the identification of the flora of this region.

3. The fear of the Lord did make us quake" George For

IJohn James (Leforest) Audubon, born in Les Cajes, Haiti, Apr. 26, 1785; died in New York City, Jan, 27, 1851 .

Thomas Say, b. Philadelphia. July 27, 1787; d. New Hanmony, Ind, Oct, 10, 1834

John Kirk Townsend, b. Ph- Tadelphia, Oct 10, 1809; d. Washingtun, D. C. Feb. 6, 1851.

"Westovwn Under the Old and New Rezime, by B. J. Leedom

TWulliam Price Townsend, b. West Chester, Ang 5. 1813; d. West Chester, Alg, 24, 1902

Philip Price Sharples, b. West Chester, Apr. 26 , $1810 ;$ d. West Chester, Jan I4 1902

John Cassio, b. Providence Twp, Delaware Ca, Sept 6, 1813; d. Pliladelphia, Jan 10, 1869

inhomes Bellerby Wilson, b. Philadelphia, Jan 17, 1807; d. Philadelphia, Mar. 5, 1865.

IIBenjumin Matlack Ereatart, b. Wext Whioland $T$ wp, Mar. 24, 1818; d. Wert Chester, Sept. 22, IgO4

IJWiliam Llond Baty, b. Ptadelghin, May 28, 1828 ; d. Philadelphia, Mar. 25, 1861.

1suacias (Carpbeli) Duncan Price

"Heary B. Gruves, b. Wet Chester, 18r9; d. Robbinson Twp, Berlos Co, Mar. 7, 1887- 


\section{The Ornithology of Chester County}

${ }^{15}$ George Archibold McCall, b. Philadelphia, Mar. 16, 1802; d. West Goshen Twp., Feb. 25, 1868.

${ }^{16}$ Edward Drinker Cope, b. Philadelphia, July 28, 1840; d. Philadelphia, Apr. 12, 1897.

${ }^{17}$ Joseph Webster Sharp, b. Yorkshire, England, 1828; d. Berwyn, Mar. 31, 1908.

${ }^{18}$ Willis Price Hazard, b. Hunteville, Ala., July 22, 1825; d. Seccane, Delaware Co., Feb. I8, 1912. ${ }^{19}$ Graceanna Lewis, b. West Vincent Twp., Aug. 3, 1821 ; d. Media, Delaware Co., Feb. 26, 1912.

${ }^{20}$ Natural History of Birds, | Lectures on Ornithology | in Ten Parts, | By | Grace Anna Lewis | Part I. "The little birds sang East, and the little birds sang West-| TOLL SLOWLY!| And but little thought was theirs, of the silent antique years, | In the building of their nest." $|-|$ J. A. Bancroft \& Co. 512 Arch St., Philadelphia.| 12mo., pp. (I) -32 .

${ }^{21}$ Mrs. John Oberholtzer, nee Vickers, b. Uwchlan Twp., May 20, I84I.

${ }^{22}$ Vincent Barnard, b. East Marlsborough Twp., Aug. 27, 1825; d. Kennett Square, Apr. 25, 1871.

${ }^{23}$ Ezra Michener, b. London Grove Twp., Nov. 24, I 794; d. New Garden, June 24, 1887.

${ }^{24}$ Christopher D. Wood, d. Philadelphia, Oct. 15, 1889, in his 47 th year.

${ }^{25}$ Harry Garrett, b. Willistown Twp., Sept 11, 1838; d. West Chester, June 25, 1904.

${ }^{26}$ Josiah Hoopes, b. West Chester, Nov. 9, 1832 ; d. West Chester, Jan. 16, 1904.

${ }^{27}$ Evan Jackson Darlington, b. Chester Co., Aug. 
31, 1856; d. Wilmington, Del., Aug. 7, 1915.

${ }^{28}$ Jonathan Hoopes Matlack, b. near West Chester, Sept. 28, 1832; d. West Chester, Jan. I, 1916. ${ }^{29}$ Bernard Adolphus Hoopes, d. New Mexico, 1896.

${ }^{30}$ John Krider, b. Philadelphia, Feb. 17, 1813; d. Philadelphia, Nov. 12, 1886.

${ }^{31}$ George Williamson Roberts, b. East Bradford Twp., July 17, 1865; d. East Bradford Twp., Aug. 29, 1913.

${ }^{32}$ Moses Pennock Barnard, b. Kennett Square, Oct. 24, 1860; d. Kennett Square, Jan. I, 1898. ${ }^{33}$ William Smedley Hall, b. Willistown Twp., July 26, 1866, d. Willistown Twp., Jan. 6, 1890. ${ }^{34}$ Willett Enos Rotzell, b. Philadelphia, June 19, 1871 ; d. Philadelphia, July 16, 1913.

${ }^{35}$ Joseph Parker Norris, b. Philadelphia, Nov. 3, 1847 ; d. Philadelphia, Mar. 17, 1916.

${ }^{36}$ Charles John Pennock, b. Kennett Square, Nov. 18, 1857; disappeared May 15, 1913.

${ }^{37}$ Since Dr. Warren in his later works has also accepted Michener's hypothetical species, it is interesting to observe how easily an evident error can be perpetuated. In the instance of M.g.grieseus Dowitcher, in which he gave Michener (I88I) as his authority for its occurrence in Chester county (Bds. Pa., 235), and a year or so later, no doubt with the above in mind; stated that specimens had been taken (Ibid. 2nd ed., 83), and in 1892 , Stone gives Warren's later statement as his authority for a Chester county record (Bds. E. Pa. and N. J., 72). ${ }^{38}$ Thomas Harrison Montgomery, b. New York, 
Mar. 5, 1873; d. Philadelphia, Mar. 19, 1912. ${ }^{39}$ Francis Windle, b. West Marlborough Twp.; d. West Chester, Feb. 24, 1917, in his 72nd year. ${ }^{40}$ Alexander Wilson observed that one was shot a few years ago (prior to 1814 ) on the borders of the Schuylkill river, below Philadelphia. No doubt this is the authority for Turnbull's record. The breeding female reported taken near Phœenixville, was really shot near a herony on the Perkiomen creek in Montgomery county, Apr. 4, 1892. It is worthy of note that all these State records have been made not far apart.

${ }^{41} \mathrm{Cf}$. Coues and Prentiss in their list of land birds of the District of Columbia, Ann. Rep. Board of Regents Smith. Inst. for the year 1861, p. 415, for similar record.

${ }^{42}$ According to B. M. Everhart of West Chester, there were seen in Chester county at irregular intervals between 1852 and 1854 the true Aluda arvensis Skylark from a flock liberated near Wilmington, Del. Cf. Warren, Bds. Pa., 1890, p. 198.

${ }^{48} \mathrm{Dr}$. Chapman in a series of 51 breeding males taken at West Chester by Dr. B. H. Warren and G. W. Roberts, found two specimens almost typical of Q. q. aglaus Florida Grackle. Cf. Bull. N. Y. Mus. Nat. Hist., iv, 12. 




THIS BOOK IS DUE ON THE LAST DATE STAMPED BELOW

AN INITIAL FINE OF 25 CENTS WILL BE ASSESSED FOR FAILURE TO RETURN THIS BOOK ON THE DATE DUE. THE PENALTY WILL INCREASE TO 50 CENTS ON THE FOURTH DAY AND TO $\$ 1.00$ ON THE SEVENTH DAY OVERDUE.

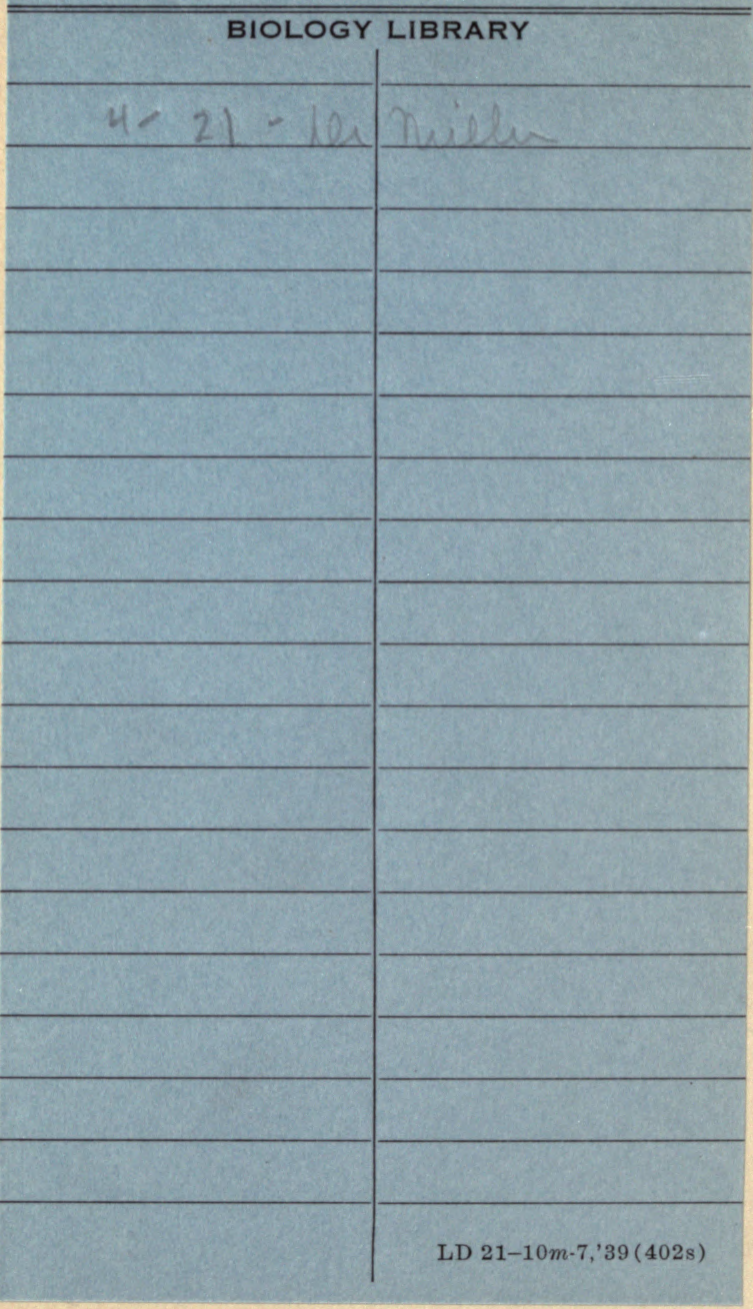




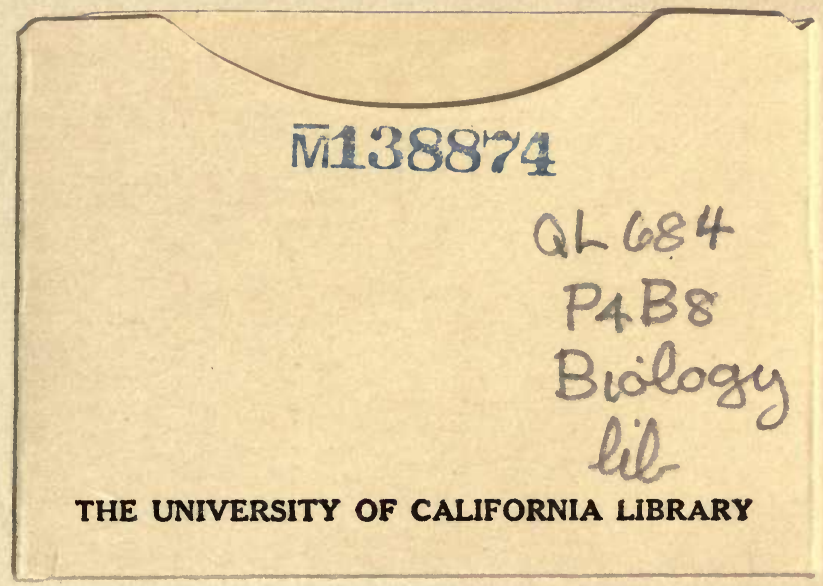




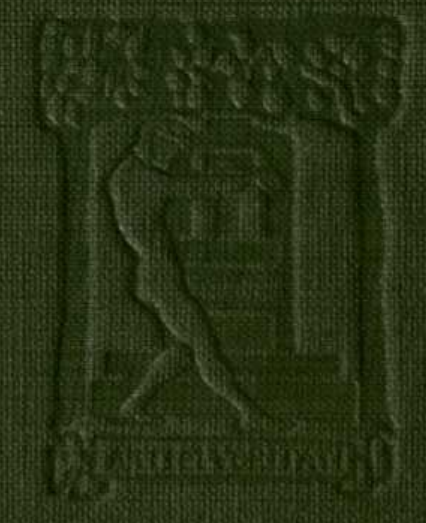

